ESTUDO DE COMPOSTOS QUIMICOS NA QUEBRA DE DORMENCIA DAS GEMAS, NA BROTACAOO E NA PRODUTIVIDADE DA VIDEIRA CULTIVAR NIAGARA ROSADA NAS PRINCIPAIS REGIOES PRODUTORAS DO ESTADO DE SAO PAULO

\author{
ERASMO JOSË PAIOLI PIRES \\ Engenheiro Agrōnomo
}

Orientador: Dr. CELSO VALDEVINO POMMER

Tese apresentada à Escola Superior de Agricultura "Luiz de Queiroz", da Universidade de São Paulo, para obtençao do título de Doutor em Agronomia, Área de Concentracáo: Fitotecnia.

$$
\begin{gathered}
\text { P I R A C I C A B A } \\
\text { Estado de Sào Paulo - Brasil } \\
\text { Março - } 1995
\end{gathered}
$$


1 . तो Mivisär de bibliatece e Documentacto - FCLG/UGF

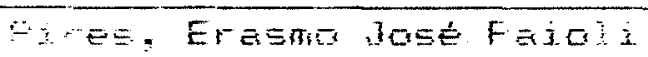

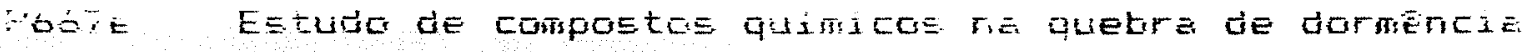

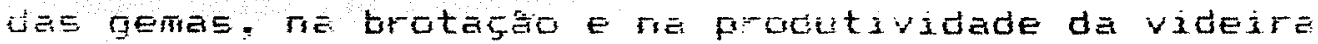

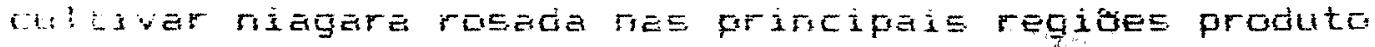

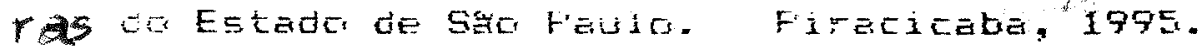
25 i.

TESE - ESALC

Fitaliogratia.

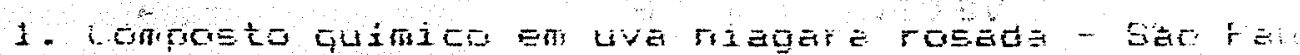
io (Estado) 2. Semente - Guetra da dormencie - Eteit: de composto quimico - Uva niagara rosada - Erotaga -

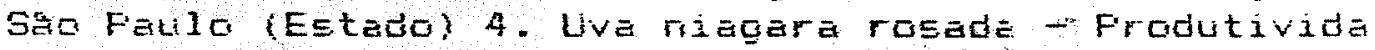
dE - SaO Faulo (Estado) 5. Uva niagara rosada - Semen te - Cuetra de dormencia I. Escola Superior de Agricli ture Luiz de Gueiroz, Firacicatea 
ESTUDO DE COMPOSTOS QUÍMICOS NA QUEBRA DE DORMÊNCIA DAS GEMAS, NA BROTAÇÃO E NA PRODUTIVIDADE DA VIDEIRA CULTIVAR NIAGARA ROSADA NAS PRINCIPAIS REGIÕES PRODUTORAS DO ESTADO DE SÃO PAULO

\section{ERASMO JOSÉ PAIOLI PIRES}

Aprovada em: 16/03/1995

Comissão Julgadora:

Prof. Dr. Fernando Mendes Pereira FCAV - UNESP

Prof. Dr. Celso Valdevino Pommer ESALQ - USP

Prof. Dr. Maurilo Monteiro Terra ESALQ - USP

Dr. Mário José Pedro Júnior IAC

Dr. Joel Irineu Fahl

Prof Dr. CELSO VALDEVINO POMMER Orientador 


\section{HOMENAGEM}

Instituto Agronômico de Campinas - IAC

Escola Superior de Agricultura "Luiz de Queiroz" - ESALQ

Conselho Nacional de Desenvolvimento Científico e Tecnológico $\mathrm{CNPq}$ 
Aos meus queridos pais

Mário Pires e

Maria Aparecida Paioli Pires,

aos quais devo meu caráter, minha honestidade e meu senso de justiça.

Dedico 
À minha querida esposa e amante Cleide Tecchio Pires companheira de todos os momentos Ofereço 


\section{AGRADECIMENTOS}

Ao Instituto Agrônomico de Campinas e à Escola Superior de Agricultura "Luiz de Queiroz", pela oportunidade concedida para a realização do Curso de Pós-Graduação.

Ao Conselho Nacional de Desenvolvimento Científico e Tecnológico - CNPq, pela bolsa concedida.

Aos amigos viticultores Luis Carbonari (que tanta saudade nos deixou) e Hilário Caniato, Ismael Secco e Ataliba Tomazeto pela permissão de uso de seus vinhedos nas regiões de Jundiaí, Indaiatuba e São Miguel Arcanjo respectivamente, sem o que não seria possivel a realização deste trabalho.

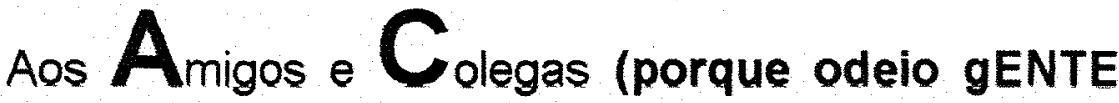
fingida, hipócrita, medíocre e mesquinha) que, de forma direta ou indireta, deram sua orientação, colaboração e incentivo na execução deste trabalho.

\section{E.J.P.P,}




\section{SUMÁRIO}

LISTA DE FIGURAS

Página

LISTA DE TABELAS

vi

viii

RESUMO

$x$

SUMMARY

xii

1. INTRODUÇÃO

2. REVISÃO DE LITERATURA 3

2.1. Estudo de compostos químicos em fruticultura 3

2.2. Estudo da aplicação da calciocianamida na cultura da videira.

2.3. Estudo da aplicaçăo da cianamida hidrogenada na cultura da videira

3. MATERIAL E MÉTODOS

3.1. MATERIAL

3.1.1. Cultivar copa

3.1.2. Cultivares porta-enxertos

3.1.3. Compostos químicos utilizados $\quad 26$

\subsection{Métodos}

$\begin{array}{ll}\text { 3.2.1. Regiâo de Jundiaí } & 27\end{array}$

3.2.2. Região de Indaiatuba $\quad 29$

3.2.3. Região de São Miguel Arcanjo $\quad 31$

4. RESULTADOS E DISCUSSÃO $\quad 34$

4.1. Região de Jundiaí 34

4.2. Região de Indaiatuba $\quad 55$

4.3. Regiåo de São Miguel Arcanjo $\quad 65$

5. CONCLUSÕES $\quad 78$

REFERÊNCIAS BIBLIOGRÁFICAS $\quad 80$

APÊNDICES $\quad 89$ 


\section{LISTA DE FIGURAS}

Figura

Página

1. Efeito de concentrações crescentes de $\mathrm{H}_{2} \mathrm{CN}_{2}$ no número de dias para brotar (dados transformados em $\sqrt{x+0,5}$ ) da videira Niagara Rosada. Jundiaí. 1992.

2. Efeito de concentrações crescentes de $\mathrm{H}_{2} \mathrm{CN}_{2}$ na porcentagem de brotação (dados transformados em arc sen $\sqrt{x+0,5}$ ) da videira Niagara Rosada. Jundiai. 1992.

3. Efeito de concentrações crescentes de $\mathrm{H}_{2} \mathrm{CN}_{2}$ no ciclo, medido da poda a colheita (dados transformados em $\sqrt{x+0,5}$ ) da videira Niagara Rosada. Jundiaí. 1992.

4. Efeito de concentrações crescentes de $\mathrm{H}_{2} \mathrm{CN}_{2}$ no número de cachos por planta (dados transformados em $\sqrt{x+0,5}$ ) da videira Niagara Rosada. Jundiaí. 1992.

5. Efeito de concentrações crescentes de $\mathrm{H}_{2} \mathrm{CN}_{2}$ na produção por planta (dados transformados em $\sqrt{x}$ ) da videira Niagara Rosada. Jundiaí. 1992.

6. Efeito de concentraçס̃es crescentes de $\mathrm{H}_{2} \mathrm{CN}_{2}$ no número de dias para brotar (dados transformados em $\sqrt{x}$ ) da videira Niagara Rosada. Indaiatuba. 1993.

7. Efeito de concentrações crescentes de $\mathrm{H}_{2} \mathrm{CN}_{2}$ no ciclo, medido em dias da poda à colheita (dados transformados em $\sqrt{x}$ ) da videira Niagara Rosada. Indaiatuba. 1993.

8. Efeito de concentraçőes crescentes de $\mathrm{H}_{2} \mathrm{CN}_{2}$ na porcentagem de brotação das gemas principais (dados transformados em arc sen $\sqrt{x}$ ) da videira Niagara Rosada. São Miguel Arcanjo. 1991.

9. Efeito de concentrações crescentes de $\mathrm{H}_{2} \mathrm{CN}_{2}$ na porcentagem de brotação das gemas velhas (dados transformados em arc sen $\sqrt{x}$ ) da videira Niagara Rosada. São Miguel Arcanjo. 1991.

10. Efeito de concentrações crescentes de $\mathrm{H}_{2} \mathrm{CN}_{2}$ na porcentagem e brotação total de gemas (dados transformados em arc sen $\sqrt{x}$ ) da videira Niagara Rosada. 
São Miguel Arcanjo. 1991.

11. Efeito de concentraçóes crescentes de $\mathrm{H}_{2} \mathrm{CN}_{2}$ no úmero de cachos por planta (dados transformados em $\sqrt{x}$ ) da videira Niagara Rosada. São Miguel Arcanjo. 1991.

12. Efeito de concentrações crescentes de $\mathrm{H}_{2} \mathrm{CN}_{2}$ no peso médio de cacho (dados transformados em $\sqrt{x}$ ) da videira Niagara Rosada. São Miguel Arcanjo. 1991.

13. Efeito de concentrações crescentes de $\mathrm{H}_{2} \mathrm{CN}_{2}$ na produção por planta (dados transformados em $\sqrt{x}$ ) da videira Niagara Rosada. Sẫo Miguel Arcanjo. 1991. 


\section{LISTA DE TABELAS}

Tabela

Página

1. Análise de variância relativa aos dados de dias para brotar. Experimento 1, Jundiaí, 1992.

2. Médias de tratamentos dentro das épocas de poda, da variável dias para brotar (dados transformados em $\sqrt{x+0,5}$ ). Experimento 1, Jundiai, 1992.

3. Análise de variância dos dados de porcentagem de brotação de gemas; Experimento 1, Jundiai, 1992.

4. Médias e tratamento dentro de épocas de poda, da variável porcentagem de brotação de gemas (dados transformados em arc sen $\sqrt{x+0,5}$. Experimento 1, Jundiaí, 1992.

5. Análise de variáncia dos dados de ciclo Experimento 1 , Jundiaí, 1992.

6. Médias de tratamentos dentro de épocas de poda, da variável ciclo, avaliado em dias contados da poda à colheita (dados transformados em $\sqrt{x+0,5}$ ). Experimento 1, Jundiaí, 1992.

7. Análise de variância dos dados de número de cachos por planta. Experimento 1, Jundiaí, 1992

8. Médias de tratamentos dentro de épocas de poda da variável número de cachos por planta. (dados transformados em $\sqrt{x+0,5}$ ) Experimento 1, Jundiaí, 1992.

9. Análise de variância dos dados de peso médio do cacho. Experimento 1, Jundiai, 1992.

10. Médias de tratamento dentro de épocas de poda, da variável peso médio de cacho (dados transformados em $\sqrt{x+0,5}$ ). Experimento 1, Jundiai, 1992.

11. Análise de variância dos dados de peso total dos cachos por planta, Experimento 1, Jundiaí, 1992.

12. Médias de tratamento dentro de épocas de poda, da variável peso dos cachos por planta (dados transformados em $\sqrt{x+0,5})$. Experimento 1, Jundiaí, 1992.

13. Resultados obtidos no Experimento 2, na região de Jundiai 
e resumo da análise de variância dos tratamentos com doses crescentes de $\mathrm{H}_{2} \mathrm{CN}_{2} .1992$.

14. Análise de variância da regressão polinomial para os niveis dos dados de tratamento. Peso médio do cacho. Experimento 2, Jundiai, 1992.

15. Resultados obtidos no experimento 1 , na região de Indaiatuba e resumo da análise de variância. 1993.

16. Resultados obtidos no Experimento 2 (A.1), na região de Indaiatuba e resumo da análise de variância.

17. Resultados obtidos no Experimento 2 (A.2), na região de Indaiatuba e resumo da análise de variância dos tratamentos com doses crescentes de $\mathrm{H}_{2} \mathrm{CN}_{2} .1993$.

18. Resultados obtidos no Experimento 1 (A.1), na região de São Miguel Arcanjo e resumo da análise de variância dos tratamentos com doses crescentes de $\mathrm{H}_{2} \mathrm{CN}_{2} .1993$.

19. Resultados obtidos no Experimento 1 (A.2), na região de São Miguel Arcanjo e resumo da análise de variância dos tratamentos com doses crescentes de $\mathrm{H}_{2} \mathrm{CN}_{2} .1993$.

20. Resultados obtidos no Experimento 2 na região de São Miguel Arcanjo e resumo da análise de variância dos tratamentos com doses crescentes de $\mathrm{H}_{2} \mathrm{CN}_{2} .1992$. 


\title{
ESTUDO DE COMPOSTOS QUIMICOS NA QUEBRA DE DORMÊNCIA DAS GEMAS, NA BROTAÇĂO E NA PRODUTIVIDADE DA VIDEIRA CULTIVAR NIAGARA ROSADA NAS PRINCIPAIS REGIÓES PRODUTORAS DO ESTADO DE SÃO PAULO
}

\author{
Autor: MS. PqC. ERASMO JOSÉ PAIOLI PIRES \\ ORIENTADOR: Prof. Dr. CELSO VALDEVINO POMMER
}

\section{RESUMO}

A necessidade de um periodo mínimo de frio no inverno para que fruteiras decíduas de regiões de clima temperado apresentem uma brotação vigorosa e uniforme na primavera seguinte, tem sido amplamente aceita.

A videira, espécie decídua típica de zona de clima temperado, é largamente cultivada em regiōes tropicais e subtropicais, como nas zonas de cultivo do Estado de São Paulo, nas quais as temperaturas mínimas que ocorrem no período de repouso nem sempre atendem as necessidades de frio requeridas pela espécie. Embora nessas regiøes geralmente ocorram deficites hídricos durante 0 inverno, que poderiam complementar as exigências para o período de repouso, estes tem sido insuficientes, conduzindo geralmente a uma brotação tardia, reduzida e desuniforme, acarretando quase sempre quedas pronunciadas na produtividade.

Procurou-se, neste trabalho, estudar o efeito do nitrato de potássio, do nitrato de cálcio e da cianamida hidrogenada, na quebra da dormência de gemas, no desenvolvimento dos ramos e na produção da videira Niagara Rosada comparados com a calciocianamida, tradicional promotor da quebra de dormência de gemas de videira em Jundiaí, Indaiatuba e São Miguel Arcanjo, três das principais zonas de cultivo da uva Niagara Rosada.

Em Jundiaí foram conduzidos dois experimentos, sendo um comparando a ação da cianamida hidrogenada $\left(\mathrm{H}_{2} \mathrm{CN}_{2}\right)$ a $1 \%, 2 \%, 3 \%$ e $4 \%$ com a calciocianamida $\left(\mathrm{CaCN}_{2}\right) 20 \%$ em dez podas semanais consecutivas, e outro em uma só época de poda, utilizando doses crescentes de $\mathrm{H}_{2} \mathrm{CN}_{2}$ $(0,0 \% ; 1,0 \% ; 1,25 \% ; 1,5 \%, 1,75 \%$ e $2,0 \%)$. 
Em Indaiatuba foram conduzidos dois experimentos, sendo o primeiro comparando a açăo da calciocianamida $20 \%$, da cianamida hidrogenada de $0,0 \% ; 1,0 \% ; 1,25 \% ; 1,5 \% ; 1,75 \%$ e $2 \%$, do nitrato de potássio $(5 \%)$ mais nitrato de cálcio $(5 \%)$ isoladamente ou adicionados à calciocianamida $(5 \%)$ e à cianamida hidrogenada $0,25 \%$, e o segundo comparando doses crescentes de cianamida hidrogenada $(0,0 \% ; 1,0 \% ; 1,25 \% ; 1,5 \% ; 1,75 \%$ e $2,0 \%$ ) isoladamente ou comparadas com calciocianamida $20 \%$.

Em São Miguel Arcanjo foram conduzidos dois experimentos, um estudando doses crescentes de $\mathrm{H}_{2} \mathrm{CN}_{2}(1 \% ; 2 \%, 3 \%, 4 \%$, $5 \%$ e $6 \%$ ) e $\mathrm{CaCN}_{2} 20 \%$; e outro estudando doses crescentes de $\mathrm{H}_{2} \mathrm{CN}_{2}$ $(1,0 \% ; 1,25 \% ; 1,5 \% ; 1,75 \%$ e $2 \%)$

De modo geral, pode-se concluir que a calciocianamida $20 \%$ e a cianamida hidrogenada tiveram 0 mesmo efeito positivo para as características avaliadas nas três regiōes. Para a região de Jundiaí, à exceção das podas tardias realizadas em setembro nas quais as plantas brotaram e desenvolveram normalmente sem auxilio de produtos químicos indutores, a concentração de cianamida recomendada situou-se na faixa de 1,44 a 1,63\%; para Indaiatuba situou-se na faixa de 1,25 a 1,66\%; finalmente para Săo Miguel Arcanjo na concentração de $1 \%$. 


\title{
INFLUENCE OF CHEMICAL COMPOUNDS ON BUD BREAK, SHOOT FORTH, AND ON THE YIELD OF NIAGARA ROSADA GRAPEVINE IN THE MAIN GRAPE REGIONS OF SÃO PAULO STATE
}

\author{
Author: MS. Eng ${ }^{\circ}$ Agr $^{\circ}$ ERASMO JOSÉ PAIOLI PIRES \\ Adviser: Prof. Dr. CELSO VALDEVINO POMMER
}

\section{SUMMARY}

The need of deciduous trees for a minimum cold winter in order to obtain vigorous bud burst and uniform shoot development in the spring is highly admitted.

The grapevine, although a tipical deciduous specie from temperate zone, it is largely cultivated in tropical and subtropical regions, like in most places of Såo Paulo State, where the minimum temperatures that occur during the rest period do not reach the amount of coldness required by this specie. Water deficit during winter is common in those regions, which could complement the demand for a rest period, but this is insufficient, most of time leding to a late, reduced and irregular bud burst and shoot forth, with severe consequences on yield.

It was studied the effect of potassium and calcium nitrates and hydrogen cyanamide on breaking dormancy, on shoot development and on yield of grape cV. Niagara Rosada. Comparisons were made among those compounds and calcium cyanamide, which is the chemical traditionally used for breaking dormancy in grapevines at Jundiaí, Indaiatuba and São Miguel Arcanjo, three of the most important regions for cultivation of Niagara Rosada.

Two trials were carried out at Jundiaí, one of them comparing the effect of hydrogen cyanamide at $1 \%, 2 \%, 3 \%$ e $4 \%$ concentrations and that of calcium cyanamide $\left(\mathrm{CaCN}_{2}\right) 20 \%$, applied at 10 consecutive weekly prunings. The other trial was established in only one pruning date comparing increasing $\mathrm{H}_{2} \mathrm{CN}_{2}$ dosis $(0.0 \%, 1.0 \% 1.25 \%, 1.5 \%, 1.75 \%$ and $2 \%)$.

Two other experiments were carried out at Indaiatuba, being the first one to compare the action of $\mathrm{CaCN}_{2}(20 \%), \mathrm{H}_{2} \mathrm{CN}_{2}(0.0 \%, 1.0 \%$, 
$1.25 \%, 1.5 \%, 1.75 \%$ and $2.0 \%)$ potassium nitrate $5.0 \%$ plus calcium nitrate $5 \%$, these latest two alone or added to $\mathrm{CaCN}_{2}(5 \%)$ and to $\mathrm{H}_{2} \mathrm{CN}_{2}(0.25 \%)$. The second experiment in this region was designed to compare increasing $\mathrm{H}_{2} \mathrm{CN}_{2}$ dosis $(0.0 \%, 1.0 \%, 1.25 \%, 1.5 \%, 1.75 \%$ and $2.0 \%)$ or compared to $\mathrm{CaCN}_{2} 20 \%$.

At São Miguel Arcanjo, one of the two experiments carried out aimed to compare increasing $\mathrm{H}_{2} \mathrm{CN}_{2}$ doses ( $1 \%, 2 \%, 3 \%, 4 \% 5 \%$ and $6 \%$ ) and $\mathrm{CaCN}_{2} 20 \%$, the other was to study only the effect of increasing $\mathrm{H}_{2} \mathrm{CN}_{2}$ $(1.0 \%, 1.25 \%, 1.5 \%$ e $1.75 \%$ and $2.0 \%)$

From the results of all the experiments it could be concluded that $\mathrm{CaCN}_{2} 20 \%$ and $\mathrm{H}_{2} \mathrm{CN}_{2}$ at different concentrations, had a similar positive effect on the grapevine caracteristics evaluated in the three regions. The best results for $\mathrm{H}_{2} \mathrm{CN}_{2}$ concentrations were: at Jundiai, from 1.44 to $1.63 \%$; at Indaiatuba, from 1.25 to $1,55 \%$; at São Miguel Arcanjo, $1 \%$. 


\section{INTRODUÇÃO}

A área cultivada com videiras no Estado de São Paulo, segundo dados do Instituto Brasileiro de Geografia e Estatística - IBGE, é de 10.200 ha. Nessa área são produzidas $110.608 \mathrm{t}$ de uva, com uma produtividade média de $14.166 \mathrm{~kg} / \mathrm{ha}$. São Paulo ocupa o segundo lugar em área plantada e o primeiro em produtividade por metro quadrado (ANUÁRIO ESTATÍSTICO DO BRASIL, 1992). Esses montantes representam $0,102 \%$ da área mundial ocupada pela videira e $0,38 \%$ da produção mundial (SITUATION de la viticulture dans le monde en 1993). A produtividade de $1,41 \mathrm{~kg} / \mathrm{m}^{2}$ no Estado de São Paulo, a despeito do clima subtropical não ser muito favorável para a cultura da videira, encontra-se entre as melhores do mundo $\left(0,371 \mathrm{~kg} / \mathrm{m}^{2}\right)$ e isso se deve ao elevado nivel de tecnificação do viticultor paulista.

A cultura de uvas rústicas de mesa, com base no cultivar Niagara, e principalmente sua mutaçăo natural Niagara Rosada, encontra-se distribuida por várias regiões do Estado de São Paulo, sendo as principais as de Jundial, Indaiatuba, Porto Feliz e São Miguel Arcanjo.

A produção dessas regióes é comercializada unicamente no mercado interno, no período que vai de fins de novembro a março, dependendo das condições microclimáticas em que as uvas são produzidas.

As videiras, como outras plantas deciduas, apresentam um período de dormencia requerendo certa quantidade de frio para retomar seu desenvolvimento na primavera. Elas sâo, em geral, pouco exigentes em frio, e quando cultivadas em regiões tropicais podem até vegetar continuamente. Por outro lado, uma vez que a dormência tenha sido estabelecida, o frio é necessário para quebrá-la e levar uma abertura uniforme das gemas.

Muitos compostos químicos como óleo mineral, dinitro-ortocresol, tiouréia, nitrato de potássio, nitrato de cálcio, ácido giberélico e cinetina são citados como efetivos na quebra de dormência de muitas espécies de 
frutiferas. Esses compostos podem substituir parcialmente a necessidade de frio e estimular uma abertura precoce e mais uniforme das gemas.

A videira, entretanto, não responde muito bem a esses compostos, e quando isso ocorre os resultados não săo expressivos. Entretanto, ela responde bem a compostos que contenham cianamida, como é o caso da calciocianamida e da cianamida hidrogenada.

Procurou-se neste trabalho estudar o efeito do nitrato de potássio, nitrato de cálcio e da cianamida hidrogenada na quebra de dormência de gemas, na brotação e na produtividade da videira Niagara Rosada, comparados com a calciocianamida, composto tradicionalmente usado, nas principais regiões viticolas do Estado de São Paulo, 


\section{REVISÃO DE LITERATURA}

\subsection{Estudo de compostos químicos em fruticultura}

HATCH \& RUIZ (1987) estudaram a influência da data de poda nas variedades de videira Perlette, Cardinal e Thompson Seedless conduzidas em regióes de clima desértico como o Arizona, sul da Califórnia (Coachella Valley), e noroeste do México. As diferentes podas foram realizadas a partir do final de novembro até o começo de fevereiro. Os resultados indicam que a maior porcentagem e uniformidade de brotação ocorreram quando 'Perlette' e 'Thompson Seedless' foram podadas durante janeiro, enquanto que 'Cardinal' não foi sensivel à época de poda. Concluíram que 0 acúmulo de frio, a translocação e 0 armazenamento de carboidratos ou outros compostos aparentemente influem na quebra de dormência das gemas de videira. Disseram esses autores que mais estudos são necessários para classificar cultivares quanto ao requerimento em horas de frio. O conhecimento de quando as reservas da planta estão prontamente disponiveis para permitir a quebra da dormência também será útil. Até que a fisiologia da dormência de gemas seja melhor entendida e gerenciada, as conclusões deste estudo sugerem a data de poda como uma ferramenta para aumentar a quebra da dorméncia e a porcentagem de brotação de 'Perlette' e outras quando cultivadas em áreas com horas de frio insuficiente.

WALKER \& DONOHO (1959) verificaram que a aplicação de $100 \mathrm{ppm}$ de ácido giberélico, em condições de campo, foi suficiente para quebrar o repouso das gemas de pessegueiro que receberam 120 horas de frio abaixo de $7,2^{\circ} \mathrm{C}$.

De acordo com WEAVER (1959), aplicações de 10, 50 e $250 \mathrm{ppm}$ de ácido giberélico no início do outono, prolongaram a dorméncia de gemas da videira na primavera seguinte; na época de aplicação a folhagem 
ainda estava verde e os resultados mostraram que, quanto mais alta a concentração de giberelina mais atrasado é o período de brotação.

POUGET (1963) observou efeitos danosos à quebra de dormência de gemas de videira na primavera seguinte depois da aplicaçăo de $100 \mathrm{ppm}$ de ácido giberélico no momento de crescimento ativo dos brotos. Portanto, segundo o referido autor, parece que a videira tem, em presença do ácido giberélico, um comportamento oposto a outras especies lenhosas, fato inexplicado até o momento.

Macieiras e pereiras originárias de regiōes de clima frio, foram levadas para serem cultivadas na Califórnia. Nas condiçōes climáticas da Califórnia foram acometidas com a síndrome da dormência prolongada. Por se desenvolverem em regiăo de longa estaçăo favorável ao desenvolvimento e poucas horas de frio na dorméncia, plantas com esse mal apresentavam fraca e tardia emissão de brotos laterais em detrimento dos terminais, com relativa inibição dos laterais e desenvolvimento longo e vigoroso dos terminais. Assim sendo, necessitavam de poda acentuada, acarretando pequeno estímulo para brotação, demora na produção de frutos, baixo rendimento e frutos muito pequenos não comerciáveis. A aplicação de óleo mineral "Narrow Range Oil" (NRO), nas concentrações de $5 \%$ a $8 \%$ associado ao dinitro-orto-cresol (DNOC) $0,12 \%-0,165 \%$ resultou em alta produção de ramos nos anos subsequentes fazendo com isso aumentar a produção de gemas floriferas e conseqüente rendimento em frutos por planta (EREZ \& LAVEE, 1974).

HOPPING (1978), na Nova Zelândia, estudou o efeito de vários compostos químicos na quebra de dormência e no desenvolvimento dos brotos no cultivar de videira Palomino. Verificou que a aplicação de dinitro-ortocresol, tiouréia, uréia, nitrato de amônio, nitrato de potássio, nitrato de cálcio e nitrato de amônio e cálcio durante o inverno, não teve efeito na quebra de dormência e brotaçăo.

EMMERSON \& POWELL (1978) estudaram o ácido abscísico endógeno em relação ao término do repouso e brotação da videira cultivares Beta, Concord, Dutchess e White Riesling desenvolvidas em condições de campo ou casa de vegetação. Verificaram que o ácido abscísico $(A B A)$ decresceu a niveis muito baixos quando as gemas foram expostas a acúmulo de horas de frio ("chilling"). Durante a abertura das gemas ("bud burst") - ABA decresce ao seu nivel mínimo, permanecendo assim até que as folhas 
comecem a desabrochar. Aplicação de $\mathrm{ABA}, \mathrm{GA}_{3}$ ou clormequat em gemas dormentes que já foram submetidas ao frio, não teve efeito na abertura das mesmas. Os autores concluem sugerindo que se há uma interação entre acúmulo de frio e $A B A$, ela é de importância secundária na abertura das gemas.

ZIV et al. (1981) verificaram que o ácido giberélico aplicado de 0,1 a $100 \mathrm{mg} / 1$ sobre videira $\mathrm{cv}$. Queen of Vineyards produz uma camada necrótica na base da gema central e promove o desenvolvimento das gemas axilares. A aplicação de ácido giberélico sobre as folhas de videira causam necrose das gemas mais prontamente do que quando aplicado diretamente sobre as gemas. Quando é pulverizado sobre o peciolo, sua ação é 100 vezes mais ativa na produção da necrose do que a induzida somente pelo limbo. As gemas novas parecem ser mais sensiveis ao acido giberélico, pois um mínimo de $6 \times 10^{-6} \mathrm{mg}$ de $\mathrm{GA}_{3}$ já parece ser o suficiente para causar sua necrose.

No vale do Rio São Francisco, ALBUQUERQUE \& ALBUQUERQUE (1984) realizaram dois experimentos para testar a eficiência de alguns produtos químicos na quebra de dormência das gemas de videira do cultivar Itália. As plantas utilizadas nos experimentos foram conduzidas em espaldeira sendo podadas segundo sistema Cazenave. No primeiro experimento, os ramos foram mantidos na vertical e no segundo experimento os ramos foram conduzidos na vertical e torcidos. Os produtos químicos utilizados foram: tiouréia $+\mathrm{KNO}_{3}$, nas concentrações: $2 \%+5 \%$ e $4 \%+10 \%$; óleo mineral + DNBP, nas concentrações $5 \%+0,12 \%$ e $8 \%+0,12 \%$; e a combinação dos produtos: (tiouréia $\left.+\mathrm{KNO}_{3}\right)+($ óleo mineral + DNBP), nas concentrações: $(2 \%+10 \%)+$ $(5 \%+0,12 \%)$. Não houve consistência entre os resultados obtidos nos dois experimentos. A brotaçăo de gemas não atingiu $50 \%$ em nenhum dos tratamentos, embora alguns deles tenham sido significativamente superiores a testemunha. Houve sinergismo entre a torção dos ramos e os tratamentos químicos, principalmente com os produtos: tiouréia a $4 \%+\mathrm{KNO}_{3}$ a $10 \%$ e óleo mineral a $8 \%+$ DNBP a $0,12 \%$. Pode ser evidenciado como melhor tratamento o uso dos produtos: óleo mineral a $8 \%+$ DNBP a $0,12 \%$ sobre plantas com ramos torcidos, pois além de ter dado os melhores resultados, esses produtos agem também como defensivos contra pragas.

De acordo com LAVEE (1973), a dormência em gemas de plantas deciduas é governada por fatores do meio ambiente que afetam o nivel das substâncias de crescimento, que por sua vez, controlam as mudanças 
metabólicas que conduzem à quebra (ou libertação) de dormência; entretanto, o autor tem dúvidas se a redução na concentração das substancia inibidoras é responsável pela quebra de dormência e se esta redução é devida à baixa temperatura de inverno.

Para WALKER \& SEELEY (1973), deve ser aceita a hipótese de que o repouso das gemas de ávores frutiferas decíduas é regulado por um balanço entre promotores e inibidores de crescimento. $O$ balanço entre as unidades de crescimento é controlado por fatores genéticos e pelo meio ambiente.

AHMEDULLAH et al. (1986) estudaram o efeito do beta-[(4clorofenil) metil]-alfa-(1,1-dimetil)-1H-1,2,4-triazol-1-etanol (paclobutrazol) nas concentraçōes de 0 ppm, $5.000 \mathrm{ppm}, 10.000 \mathrm{ppm}$ e $20.000 \mathrm{ppm}$ na vegetaçăo e nas gemas dormentes de videira 'Concord'. A aplicação na vegetação reduziu o desenvolvimento dos ramos visto que o modo primário de ação é como de um antigiberélico, sem contudo afetar a produção e a qualidade da colheita. Quando aplicado nas gemas dormentes atrasou a brotação de 3 a 5 dias quando comparado ao controle.

SHIKHAMANY et al. (1989) estudaram o efeito de agentes químicos associados à torção das varas com o objetivo de induzir a quebra da dormência das gemas da videira Thompson Seedless, a qual apresenta uma brotação muito pobre quando cultivada em condições de clima tropical. 0 experimento foi conduzido em blocos ao acaso com dez tratamentos a saber: Paclobutrazol (PB) a 1000 e $1500 p p m$, nitrato de potássio $\left(\mathrm{KNO}_{3}\right)$ a 4 e $6 \%$, tiouréia 3 e $4,5 \%$, etefon a 2000 e $3000 \mathrm{ppm}$, vara torcida como controle 1 e vara integra como controle 2 . As videiras foram podadas uniformemente deixando-se 12 gemas por vara. Todas as varas imediatamente após a poda, à exceçăo do controle 2 , foram torcidas à mão com o objetivo de promover a ruptura do cambium e, em seguida as cinco gemas terminais das varas tratadas foram mergulhadas nas soluções contendo os produtos químicos em estudo. A torção da vara associada à aplicação de solução de tiouréia $4,5 \%$ foi a que apresentou - melhor resultado na quebra de dorméncia das gemas ao longo da vara, apresentando 3,95 gemas brotadas contra 1,7 gemas brotadas do controle 2 . Os demais tratamentos apresentaram em média 2,7 gemas brotadas versus 1,7 gemas brotadas do controle. 


\subsection{Estudo da aplicação da calciocianamida na cultura da videira}

A calciocianamida (AERO CYANAMID, s.d.) não é somente um fertilizante nitrogenado mas possui muitos efeitos. A calciocianamida é um fertilizante de múltipla ação. $O$ amplo espectro dos efeitos da calciocianamida são devidos à forma nitrogenada orgânica característica dela, isto é, um composto de carbono e nitrogênio o qual é denominado cianamida.

A calciocianamida reage no solo para nitrogênio amoniacal. Primeiramente calciocianamida e água reagem para cianamida e hidróxido de cálcio. Os múltiplos efeitos da calciocianamida, como por exemplo, herbicida e pesticida, são devidos à cianamida. Seguindo este caminho, cianamida mais agua reagem para produzir uréia e mais tarde carbonato de amônio que é finalmente transformado em nitrato $\left(\mathrm{NO}_{3}\right)$. Um caminho secundário de transformação da calciocianamida é o modo via diciandiamida, que antes de chegar a uréia passa por guaniluréia e guanidina. Dicianamida, assim como cianamida, serão transformados em nitratos vagarosamente, ou seja, não serão perdidos facilmente por lixiviação ao longo do perfil do solo.

O esquema de transformação da calciocianamida é 0

seguinte:

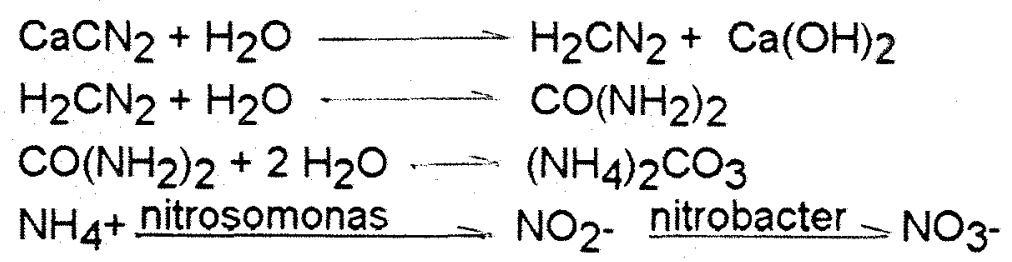

A calciocianamida $\left(\mathrm{CaCN}_{2}\right)$ foi reportada como um elemento ativo para ser usado na quebra de dorméncia de maçã e de videira. Sendo um material não solúvel em água, não pode ser usado em pulverização, devendo ser aplicada somente em pincelamento nos ramos e nas gemas das plantas (KUROI et al., 1963).

Foram estudados os efeitos da calciocianamida e do ácido giberélico na antecipação do período de maturação dos frutos do cultivar de videira Niagara Rosada. A calciocianamida foi testada na forma de solução a 10 e $20 \%$, tendo a aplicação sido realizada 3 dias antes da poda de inverno. 0 ácido giberélico, na concentração de $100 \mathrm{ppm}$, foi aplicado quando os brotos, com aproximadamente $25 \mathrm{~cm}$, apresentavam inflorescência com 3 a $4 \mathrm{~cm}$ de 
comprimento. A análise estatística dos dados relativos ao número total de brotos aos 30 e 50 dias após a poda e do número de brotos com comprimento superior a $15 \mathrm{~cm}$, aos 50 dias após a poda, antes, pois, da aplicação da giberelina, evidenciou a açăo da calciocianamida na antecipaçăo da brotaçăo das videiras, bem como permitiu a verificação da maior efetividade da solução a $20 \%$. Por outro lado, a análise estatística dos dados referentes aos índices de maturação, determinados aos 147 dias após a poda de inverno, mostrou que a associação da aplicação de calciocianamida a $20 \% \mathrm{com}$ a giberelina a $100 \mathrm{ppm}$, antecipou significativamente o periodo de maturação dos frutos (PEREIRA et al., 1979).

Em outra pesquisa, estacas da videira Moscatel de Alexandria contendo uma gema foram coletadas mensalmente de 30 de agosto a 28 de fevereiro de plantas dormentes cultivadas em casa de vegetaçăo no Japão. Vários tratamentos foram aplicados a cada época de coleta na tentativa de quebrar a dormência devido a frio deficiente. A dormência foi quebrada naturalmente em torno de 30 de janeiro. A remoção de escamas das gemas reduziu grandemente $O$ periodo de dormência durante 0 período das observações. A aplicação do sobrenadante de calciocianamida a $20 \%$ acelerou o término da dormência quando aplicado no período compreendido entre 30 de agosto a 10 de novembro; depois disso, a taxa de brotação decresceu até 27 de dezembro. A dorméncia das gemas da videira foi prolongadamente marcada pela aplicação de ácido giberélico a $100 \mathrm{ppm}$ durante o período de coleta. Etefon aplicado em 30 de novembro em gemas ainda dormentes, atrasou ainda mais o término da dormência das gemas (IWAZAKI, 1980).

KISHINO et al. (1978) estudaram o efeito da calciocianamida na brotação da videira cultivar Itália (Pirovano 65) em Londrina, PR, a 23035'S e $51015^{\prime} \mathrm{W}$. Os resultados obtidos permitiram chegar às seguintes conclusóes: a) a calciocianamida estimulou a brotaçăo da videira cultivar Itália; b) a aplicação da solução de calciocianamida no ramo todo proporcionou maior brotaçăo em relação ao tratamento somente na gema; c) tubos plásticos para cobertura dos ramos ou a cobertura total da planta, podem ser utilizados como agentes auxiliares de brotação após a aplicação de solução de calciocianamida; d) concentrações de 20,30 e $40 \%$ de calciocianamida produziram os mesmos efeitos sobre a brotação; f) o uso de adubo foliar 30-10-210 a 10\% em mistura com a soluçăo de calciocianamida proporcionou brotação mais rápida e uniforme; g)a brotação foi correlacionada diretamente com a umidade relativa do 
ar, e inversamente com a temperatura do momento de aplicação; h) com utilização racional de calciocianamida, é possivel antecipar a colheita e dar condições para se ter melhor arquitetura de plantas.

TERRA et al (1982) estudaram os efeitos da calciocianamida e de sua mistura com uréia e adubo foliar na brotação de gemas, concentração de açúcares totais no suco e produção de frutos de videira 'Niagara Rosada'. Foram efetuados os seguintes tratamentos: testemunha; adubo foliar $(20-10-10) \quad 100 \mathrm{~g} /$; uréia $45 \mathrm{~g} /$; calciocianamida $200 \mathrm{~g} /$; calciocianamida $200 \mathrm{~g} / \mathrm{l}+$ uréia $45 \mathrm{~g} /$; calciocianamida $200 \mathrm{~g} / \mathrm{l}+$ uréia $100 \mathrm{~g} / \mathrm{l}$ e calciocianamida $200 \mathrm{~g} / \mathrm{l}+$ adubo foliar $(20-10-10) 100 \mathrm{~g} /$. Verificaram que todos os tratamentos que receberam calciocianamida anteciparam em cerca de 10 dias o inicio da brotaçăo das gemas. Com relaçắo à concentraçăo de açúcares totais, os tratamentos com calciocianamida complementados com uréia ou adubo foliar mostraram-se superiores à testemunha. Os tratamentos somente com uréia ou adubo foliar comportaram-se estatisticamente semelhantes à testemunha. Os autores observaram que os tratamentos com calciocianamida não afetaram significativamente a produção, havendo porém, tendéncia de eles apresentarem valores menores em relação à testemunha. Os efeitos da calciocianamida, nas características estudadas, não foram significativamente afetados pela adição de uréia ou adubo foliar.

PEREIRA \& OLIVEIRA (1978) estudaram os efeitos de diferentes formas de aplicação de calciocianamida sobre a antecipação da brotação e da produção e da época de produção do cultivar de videira Niagara Rosada. A solução de calciocianamida a $20 \% \mathrm{p} / \mathrm{v}$ foi aplicada através dos seguintes tratamentos: pulverização do cordăo esporonado; pincelamento das gemas e cortes deixados pela poda; pincelamento das gemas; pincelamento dos cortes e testemunha. Para avaliação dos resultados foram feitas contagens: do número total de brotos aos 15, 29 e 42 dias, após a poda; do número de brotos mais desenvolvidos, aos 29 e 42 dias após a poda, além da avaliação da produção através de colheitas semanais. Os tratamentos com calciocianamida proporcionaram a formação de maior número de brotos, bem como brotos mais desenvolvidos quando comparados com a testemunha. $O$ tratamento que constou de pincelamento das gemas e dos cortes, mostrou-se superior aos tratamentos onde se fizeram aplicações localizadas exclusivamente nos cortes ou nas gemas. A aplicação através de pulverização mostrou resultados bastante 
satisfatórios. Sem afetar a produção total, todos os tratamentos com calciocianamida proporcionaram a antecipação da colheita, o que foi observado pela análise nas duas primeiras semanas de colheita.

TERRA et al. (1987) estudaram os efeitos de doses e modo de aplicação de calciocianamida na brotação e na produção de videira Niagara Rosada'. O experimento foi conduzido em Jundial na latitude $23^{\circ} 08^{\circ} \mathrm{S}$ e altitude de $730 \mathrm{~m}$. Os tratamentos consistiram na aplicação de calciocianamida imediatamente após a poda, nas concentrações de $0,70,140$ e $210 \mathrm{~g} / 1$ na forma de pincelamento total do cordão esporonado ou somente no corte do bacelo recém podado. Os autores concluiram que todos os tratamentos com calciocianamida anteciparam a brotação das gemas em relação à testemunha, na qual o inicio ocorreu somente 34 dias após a poda. Aos 41 dias após a poda, quando praticamente todas as gemas dos tratamentos que receberam calciocianamida encontravam-se brotadas, apenas $53,02 \%$ das gemas da testemunha haviam atingido este estádio de desenvolvimento. Verificou-se também que o tratamento com $70 \mathrm{~g}$ de calciocianamida por litro, aplicado no ramo todo, foi menos eficiente que os demais tratamentos com calciocianamida nos quais não se observaram diferenças pelo efeito de doses e modos de aplicação. Com relação à quebra de dorméncia das gemas, verificaram que, com exceçăo da dose de $70 \mathrm{~g}$ de calciocianamida por litro, aplicada no ramo todo, todos os demais tratamentos com esse produto, independentemente da dose ou modo de aplicação induziram a brotação em média de $77,2 \%$ das gemas enquanto na testemunha, permaneceram dormentes cerca de $55 \%$ das gemas. Observaram também que, independentemente da dose e modo de aplicação, todos os tratamentos com calciocianamida anteciparam a maturação dos cachos em relação à testemunha. Verificaram que nesses tratamentos o periodo de colheita foi antecipado em 18 dias, quando iniciou-se a colheita na testemunha, que se prolongou ainda por mais 12 dias. Quanto a produçåo, as plantas tratadas foram superiores ao controle, à exceção do tratamento que recebeu aplicação de calciocianamida 70 gramas/litro aplicada no ramo todo.

No Rio Grande do Sul, a pulverizaçăo da calcio- cianamida $\left(\mathrm{CaCN}_{2}\right)$ em varas de videira cv. Cabernet Franc (Vitis vinifera L.), por ocasião da poda seca, nas concentraçóes de $0,5,10,20$ e $30 \%$, proporcionou um aumento linear na porcentagem de gemas brotadas, no número de cachos por vara, na fertilidade e na produção de uva por gema, na produtividade do vinhedo 
e na acidez total da uva. A solução de calciocianamida na concentraçăo de $30 \%$ foi a que apresentou os melhores resultados, pois, em relação à testemunha, proporcionou um aumento de $32,65 \%$ na brotação de gemas, de $29,59 \%$ na fertilidade por gema e de $32,45 \%$ na produtividade do vinhedo. Entretanto, causou um leve decréscimo no $\mathrm{pH}$ e na relação OBrix/acidez total da uva. Nenhuma das concentrações utilizadas causou efeito significativo nas variáveis peso por cacho, comprimento por broto, fertilidade e produção de uva por gema brotada e o teor de sólidos solúveis (MIELE et al., 1982).

Na região do vale do Rio São Francisco, a aplicação de calciocianamida em videiras do cv. Itália, por ocasiấo da poda, nas concentrações $0,10,20$ e $30 \%$, proporcionou uma resposta quadrática na porcentagem de gemas brotadas nas varas sem cobertura plástica, e na produção das plantas com varas com cobertura plástica; e uma resposta linear na porcentagem de gemas brotadas nas varas com cobertura plástica, e na produção das plantas com varas sem cobertura plástica. Nas varas sem cobertura houve um aumento de $142 \%$ de gemas brotadas com a $\mathrm{CaCN}_{2}$ a $20 \%$, e um aumento de $88 \%$ na produção para a concentração de $30 \%$. Nas varas com cobertura plástica houve um acréscimo de $203 \%$ de gemas brotadas para a $\mathrm{CaCN}_{2}$ a $30 \%$ e um acréscimo de $79 \%$ na produção para as doses de 20 a $30 \%$. A CaCN 2 năo afetou a fertilidade por gema brotada nem a composiçăo química das uvas no que se relaciona aos sólidos solúveis e acidez total (ALBUQUERQUE et al., 1986).

\subsection{Estudo da aplicação de cianamida hidrogenada na cultura da videira}

De acordo com BONNAIRE \& RIEDER (1985), a cianamida hidrogenada é um regulador de crescimento que serve para romper a dormência das gemas de plantas decíduas. O produto leva a uma brotação de gemas mais precoce e mais uniforme, aumentando a porcentagem total de brotação de gemas. A cianamida hidrogenada não é um composto químico novo. É conhecido há muito tempo por ser uma das fases da decomposição no solo do fertilizante nitrogenado calciocianamida.

A cianamida hidrogenada é uma substância muito reativa e por este motivo foi necessário levar a cabo grande quantidade de pesquisas para 
desenvolver um processo factivel, económico e livre de riscos para sua fabricaçâo comercial. Ainda que se encontrassem efeitos interessantes da cianamida hidrogenada na agricultura, seu uso não era possivel, visto seu grau industrial ter uma vida de armazenamento limitada a poucos dias, particularmente se armazenada a temperaturas acima de $20^{\circ} \mathrm{C}$. A decomposição da cianamida hidrogenada origina um precipitado que bloqueia os bicos dos pulverizadores e inclusive pode produzir uma ruptura expontânea dos tanques. Seu uso agricola só foi possivel quando foi desenvolvida uma formulação especialmente estabilizada com suficiente vida de armazenamento. 0 uso agricola da cianamida hidrogenada começou em 1972 como regulador de crescimento para lúpulo na Alemanha, seguido por uso como herbicida em vários paises europeus. O último emprego foi um regulador de crescimento baseado na formulação especial da cianamida hidrogenada para controlar a dormência em uva e outras frutas.

O modo de ação desse composto ainda não está totalmente esclarecido. Sabe-se que a cianamida hidrogenada afeta o sistema respiratório nas células e interfere em certos processos enzimáticos que, por sua vez, controlam o repouso.

A cianamida hidrogenada, sendo o primeiro produto da calciocianamida, tem sido amplamente estudada com respeito à decomposiçăo no solo e nas plantas. Ela se decompõe rapidamente no solo em uréia e amônia, e nesta forma atua como fertilizante. Nas plantas a cianamida hidrogenada é também uma fonte de nitrogênio para elaborar aminoácidos e proteínas; isto tem sido determinado com radioisótopos marcados. $A$ análise de resíduos feita na colheita tem mostrado que não se detecta nenhum residuo, inclusive ao nivel limite de detecção de $0,05 \mathrm{ppm}$.

É um produto perigoso se ingerido. Causa irritação na vista e na pele. Não se deve tomar bebida alcoólica antes, durante e 24 horas após o manuseio do produto.

PIRES et al. (1985) realizaram um ensaio com o objetivo de determinar o efeito da calciocianamida e alzodef (produto a base de $\mathrm{H}_{2} \mathrm{CN}_{2}$ ) na quebra da dormência de gemas da videira 'Niagara Rosada'. Em 28 de outubro de 1984, na região de Jundiai, duas horas depois da poda, aplicou-se calciocianamida $20 \%$ através de pincelamento no cordăo esporonado, calciocianamida $20 \%$ nos cortes da poda, pulverização com alzodef $2 \%$ e $5 \%$ no 
cordão esporonado, além do controle. Verificou-se que alzodef $2 \%$ promoveu maior precocidade na emergencia dos brotos da videira 'Niagara Rosada'. Pincelamento do cordão esporonado ou do corte da poda com calciocianamida $20 \%$ e pulverizaçăo com alzodef $2 \%$ e $5 \%$ promoveram quebra da dorméncia das gemas. Os produtos químicos aplicados não afetaram significativamente 0 número nem o peso dos cachos na colheita.

SIMANCAS et al. (1987), em Maracaibo, Venezuela, compararam o efeito do ethephon, do alzodef (produto à base de cianamida hidrogenada), e do arqueamento da vara na quebra de dorméncia e produção nos cultivares de mesa de videira Itália e Alphonse Lavallée. Em 'Itália' a quebra de dorméncia foi grandemente aumentada com aplicação de alzodef $7,5 \%$ mais arqueamento da vara. A maior produçăo (16kg/planta) foi obtida com pulverização de etefon $5.000 \mathrm{ppm}$, seguido de alzodef $7,5 \%$ mais arqueamento dos ramos. Somente $o$ arqueamento dos ramos aumentou em $41,4 \%$ a quebra de dormência. Nenhum dos tratamentos teve efeito significativo em Alphonse Lavallée, cujas plantas apresentaram $60 \%$ de brotação sem nenhum tratamento.

LIN et al. (1983) estudaram a aplicação de cianamida na quebra da dormência de gemas na videira 'Kyoho'. Verificaram que a cianamida $\left(\mathrm{H}_{2} \mathrm{CN}_{2}\right) 2 \%$ foi efetiva e comparável ao etileno cloridrin $200.000 \mathrm{ppm}$ na brotação de gemas. A aplicaçăo de cianamida $5 \%$ ou dinitro-orto-cresol $0,075 \%$ e $0,1 \%$ também induziram alguma brotação, sendo, porém, pouco efetivos. A testemunha e os tratamentos com tiouréia $0,2 \%$ e $2 \%$ permaneceram dormentes.

LIN et al. (1985), em Taiwan, $24{ }^{\circ} \mathrm{N}$, conduziram experimentos para verificar a ação de compostos químicos na indução de brotação de gemas de videira 'Golden Muscat'. Os compostos quimicos e suas concentraçōes foram: cianamida $0,98 \%$ e $2,45 \%$ e etileno cloridrin $5,0 \%$. Na época usual de poda, isto é, logo após o inverno, ambos os produtos apresentaram a mesma eficiência, quando comparados ao controle. Entretanto, 0 efeito mais espetacular foi quando solução de cianamida $2,45 \%$ foi aplicada no final de agosto imediatamente após a colheita normal. Nessa época, a cianamida provocou o desfolhamento da parreira $e$ induziu um segundo fluxo de desenvolvimento, acarretando uma segunda colheita no ano, o que proporcionou maior rendimento por hectare.

SHULMAN et al. (1983) estudaram o efeito de reguladores de crescimento na quebra da dormência de gemas de videira cvs. Perlette, de 
baixa dormência, e Dan Ben Hanna, de elevada dormência. Os compostos químicos utilizados e suas concentrações foram: controle; suspensão de calciocianamida $\left(\mathrm{CaCN}_{2}\right): 0,25 \mathrm{M}$ a $1,25 \mathrm{M}$; solução de cianamida hidrogenada $\left(\mathrm{H}_{2} \mathrm{CN}_{2}\right): 0,125 \mathrm{M}$ a $1,25 \mathrm{M}$; soluçấo de dinitro-orto-cresol (DNOC): $0,008 \mathrm{M}$, $0,04 \mathrm{M}$; tiouréia: $0,1 \mathrm{M}, 0,2 \mathrm{M}$. Após 30 dias as gemas das plantas controle permaneciam dormentes; com $\circ \mathrm{H}_{2} \mathrm{CN}_{2}$, as concentrações de $0,25-63 \mathrm{M}$ foram suficientes para fazer brotar $80 \%$ das gemas de 'Perlette', enquanto que para 'Da Ben Hanna' para se obter resultados semelhantes, a concentração necessária fol de $1,25 \mathrm{M}$. Suspensão de $\mathrm{CaCN}_{2}$ também induziu a quebra de dormencia de gemas, mas o efeito da soluçăo de $\mathrm{H}_{2} \mathrm{CN}_{2}$ foi muito mais forte. Os autores sugerem que a calciocianamida sofre uma hidrólise parcial para lon de cianamida hidrogenada os quais podem ser a forma ativa e reagir com os produtos de cianamida hidrogenada. DNOC e tiouréia também induziram a quebra de dormência de gemas, mas nas concentrações estudadas os efeitos foram muito inferiores aos da $\mathrm{H}_{2} \mathrm{CN}_{2}$. Em todos os casos, os tratamentos que propiciaram uma taxa maior de quebra de dormência de gemas mostraram um crescimento na taxa de respiração que foi medida pela evolução do $\mathrm{CO}_{2}$. Verificaram que o sobrenadante da suspensăo aquosa de calciocianamida $\left(\mathrm{CaCN}_{2}\right)$ é muito efetivo na quebra de dormência de plantas decíduas. Muitos estudos mostram que o sobrenadante contém cianamida hidrogenada $\left(\mathrm{H}_{2} \mathrm{CN}_{2}\right)$, produto da hidrólise da $\mathrm{CaCN}_{2}$. Esta substância é tida como o ingrediente ativo na quebra da dormência de gemas. Os produtos originados da polimerização ou degradação de $\mathrm{H}_{2} \mathrm{CN}_{2}$ não são ativos na quebra de dormência.

Muitos compostos quimicos são usados para induzir a quebra de dorméncia em fruteiras deciduas em áreas onde a quantidade de frio e insuficiente para induzir a brotaçăo da planta. SNIR (1983) aplicou óleo mineral + dinitro-orto cresol $5 \%, \mathrm{KNO}_{3} 5 \%$, tiouréia $1 \%$, e cianamida $4 \%$ em três cultivares de framboesa. Todos os compostos quimicos induziram a quebra de dormência; entretanto, os resultados mais espetaculares quanto a porcentagem e uniformidade de brotação, quantidade de frutos produzidos, precocidade na colheita e rendimento por área, foram obtidos com a aplicação de cianamida $4 \%$.

KUROI (1985), em Niigata, Japão, estudou o efeito da calciocianamida a $20 \%$, e de doses crescentes de cianamida hidrogenada de 0,5 a $3,0 \%$ na quebra de dormência de gemas de videira 'Kyoho' aplicadas nos meses de dezembro, janeiro e fevereiro. Verificou que doses acima de $2 \%$ 
provocaram danos letais às gemas, reduzindo sobremaneira a brotação e, por conseguinte, diminuindo a produçăo da planta. Em poda tardia, no final de fevereiro, isto é, quando a planta já teve sua dormência quebrada pelo frio, cianamida em concentraçăo superior a $1 \%$ causou injúria química às gemas. 0 autor concluiu que tanto a calciocianamida como a cianamida apresentam o mesmo efeito e a mesma eficiência na quebra de dormência de gemas de videira.

WILLIANS (1987) estudou o efeito da cianamida na quebra de dorméncia de gemas e desenvolvimento da videira Thompson Seedless no Vale do São Joaquim, na Califórnia, nos anos de 1984 e 1985 . O trabalho constou da aplicação de cianamida $2,5 \%(\mathrm{~V} / \mathrm{V})$ imediatamente após as podas realizadas em 17 de janeiro e $1^{\circ}$ de março. O número de graus dias maior que $10^{\circ} \mathrm{C}$ entre a brotação e o florescimento foi de 365 e 372 , respectivamente para os anos em estudo. Nas videiras podadas em janeiro houve um adiantamento na brotação de 3 a 7 dias, enquanto que nas podadas em março houve um atraso na brotação quando comparadas ao controle. $O$ autor não encontrou resultados estatisticamente significativos para os dados observados em ambas as datas de poda como: número de dias entre a poda e a colheita, peso médio de 100 bagas, sólidos solúveis, número de cachos por planta e rendimento por hectare.

Com o objetivo de se determinar qual o mais eficiente produto químico na brotação da videira cv. Itália, foi conduzido um experimento sob condições irrigadas na região semi-árida do vale do São Francisco. Os produtos químicos utilizados etefon 8.000 ppm, $\mathrm{H}_{2} \mathrm{CN}_{2} 3,5 \%, \mathrm{CaCN}_{2} 30 \%$ e etefon $8.000 \mathrm{ppm}+\mathrm{H}_{2} \mathrm{CN}_{2} 3,5 \%$, foram significativamente superiores à testemunha no que se refere a porcentagem de gemas brotadas e número de cachos e não influiram no parâmetro sólidos solúveis ('Brix). O tratamento $\mathrm{H}_{2} \mathrm{CN}_{2}$ foi o mais eficiente dentre os produtos utilizados; no entanto, seu uso, como dos demais produtos citados depende do custo (ALBUQUERQUE \& SOBRAL, 1989).

REDDY \& SHIKHAMANY (1989) pesquisaram o efeito da cianamida hidrogenada e tiouréia na quebra de dormência e brotação da videira 'Thompson Seedless' em condições tropicais. As videiras foram podadas em 10 de setembro, deixando-se 20 varas por planta, e cada vara contendo 11 gemas. No dia seguinte, as 5 gemas apicais foram mergulhadas em soluçб̃es aquosas a $1,5 \%, 3,0 \%$ ou $4,5 \%$ contendo $\mathrm{H}_{2} \mathrm{CN}_{2}$ ou tiouréia. O tratamento com $\mathrm{H}_{2} \mathrm{CN}_{2} 3 \%$ 
resultou em alta porcentagem de brotação, isto é, $88 \%$ de gemas brotadas, enquanto que no controle foi somente $25 \%$. Os tratamentos que receberam $\mathrm{H}_{2} \mathrm{CN}_{2}$ levaram 5-7 dias para começar a brotar, enquanto que no controle demoraram em média 16 dias. A maior produtividade por planta também ocorreu quando foi aplicada $\mathrm{H}_{2} \mathrm{CN}_{2} 3 \%$. Tiouréia foi sempre menos efetiva que a cianamida hidrogenada em todos os aspectos.

PIRES et al. (1993) avaliaram em vinhedo comercial, na região sul do Estado de São Paulo (23052'S; 40000'W), os efeitos de concentrações crescentes de 0,$24 ; 0,48 ; 0,71 ; 0,95 ; 1,19$ e $1,43 \mathrm{M}$ de $\mathrm{H}_{2} \mathrm{CN}_{2}$, $\mathrm{CaCN}_{2}$ 1,67M e controle năo tratado na brotação de gemas, na produção de cachos e no rendimento por planta de videira 'Itália'. A aplicação de $\mathrm{H}_{2} \mathrm{CN}_{2}$ foi feita através de pulverização das varas e a $\mathrm{CaCN}_{2}$ através do pincelamento das gemas, ambas realizadas imediatamente após a poda. Concluiu-se que a aplicação de $\mathrm{H}_{2} \mathrm{CN}_{2}$ em concentrações crescentes induziu um efeito altamente significativo na porcentagem de brotação de gemas, com as variações traduzidas por uma equação de regressão do primeiro grau (negativa). $O$ emprego de $\mathrm{H}_{2} \mathrm{CN}_{2} \quad 0,24 \mathrm{M}$ foi efetivo na quebra de dorméncia de gemas da videira 'Itália'. $\mathrm{H}_{2} \mathrm{CN}_{2} \quad 0,24 \mathrm{M}$ e $\mathrm{CaCN}_{2} \quad 1,67 \mathrm{M}$ tiveram eficiência semelhante na quebra da dormência das gemas, no número e peso dos cachos por planta. Os tratamentos $\mathrm{H}_{2} \mathrm{CN}_{2} \quad 0,24 \mathrm{M}$ e $\mathrm{CaCN}_{2} \quad 1,67 \mathrm{M}$ proporcionaram aumentos significativos nos parâmetros avaliados quando comparados ao controle. Nas concentrações de $\mathrm{H}_{2} \mathrm{CN}_{2} \quad 0,48 \mathrm{M}$ a $1,43 \mathrm{M}$, a drástica diminuição na porcentagem de gemas brotadas, deveu-se à morte das gemas, enquanto que no controle, as gemas não brotadas permaneceram vivas. Nos tratamentos com $\mathrm{H}_{2} \mathrm{CN}_{2}$ e $\mathrm{CaCN}_{2}$ o ciclo da videira 'Itália' foi diminuído de um mês.

AMBERGER (1984), em trabalho de revisão, relata que fatores ambientais como água, luz e pressão do oxigênio, além da ação de alguns compostos químicos podem desencadear a quebra de dorméncia, resultando em um aumento da ATP e da respiração mitocondrial. Além dos conhecimentos dos aspectos fitohormonais, cianida, cianamida, tiouréia, coumarin, etc., quando aplicadas em concentrações adequadas mostram um efeito de quebra de dormência em sementes ou gemas. Segundo 0 autor, cianida e cianamida são conhecidos inibidores da catalase e promotores da respiraçăo mitocondrial. Ambos os compostos contém o grupo muito reativo $\mathrm{C}=\mathrm{N}$ que reage com a enzima- $\mathrm{Fe}$ da catalase que, desta maneira, inibe a 
decomposição de $\mathrm{H}_{2} \mathrm{O}_{2}$ que é deletéria para as células das plantas. $\mathrm{O}$ acúmulo de $\mathrm{H}_{2} \mathrm{O}_{2}$ resultante leva a um alto conteúdo de peróxidos e de glutation, os quais, por sua vez, podem controlar o metabolismo da dormencia, tanto diretamente ou através da atividade aumentada da peroxidase, ou oxidases mais especificas ou oxidase ascorbato, a qual está muito proximamente ligada com o sistema de oxiredução do glutation nos processos de germinação. Neste respeito, o aumento da formação de arginina em alguns experimentos pode ser relatado como resultante da interação da cianamida com a cisteína que é parte do glutation oxidado. Desta maneira o aumento da peroxidase em experimentos com plântulas não é necessariamente uma consequência da inibiçăo da catalase pela cianamida. Isto não contradiz o encontrado por NIR et al. (1984) que enfatizam a direta conexăo da redução na atividade da catalase e aumento no conteúdo da peroxidase. Estas enzimas, localizadas principalmente em glioxissomos, também são responsáveis para a degradação de triglicérides nas sementes e gemas. $O$ efeito da cianida ou cianamida em promover a respiração é também explicado às vezes por favorecer a troca de EMP para PP com aumento da produção de nucleotídeo reduzido que é típico para metabolismo e sintese intensificados.

NIR et al. (1984) desenvolveram estudos sobre 0 envolvimento da catalase na dorméncia de gemas de videira. Concluiram que: 1) O decréscimo da temperatura no inverno é seguido por um decréscimo da atividade da catalase. $A$ intensidade de dormência de gemas de videira parece estar diretamente relacionada com a atividade da catalase; 2) Baixas temperaturas artificialmente criadas, cianamida e outros produtos químicos promotores de quebra de dormência, causam um decréscimo da atividade da catalase. Um composto químico menos eficiente na quebra de dorméncia como o dinitro-orto-cresol (DNOC) não causa decréscimo na atividade da catalase; 3 ) A atividade da catalase em gemas de videira, devido a produtos quimicos ou baixas temperaturas causa um aumento no nível de peróxido de hidrogênio nos tecidos das gemas. Este nivel aumentado de $\mathrm{H}_{2} \mathrm{O}_{2}$ pode causar uma ativação do caminhamento metabólico do fosfato-pentose e assim levar ao fim a dormência dando inicio à brotação das gemas e ao rápido crescimento.

SHULMAN et al. (1986) constataram que a cianamida hidrogenada é um eficiente agente na quebra de dormência em plantas decíduas cultivadas em clima quente. Pulverização de $\mathrm{H}_{2} \mathrm{CN}_{2} \quad 1-5 \%$ induziu a uma total, 
precoce e uniforme quebra de dormência em amêndoa, maçã, actinídia, figo, uva, pêssego, caqui e ameixa. Imersão de sementes de videira por 5 minutos em solução aquosa com $\mathrm{H}_{2} \mathrm{CN}_{2} 1 \%$ substituiu a exigência em frio e induziu a germinaçăo. A aplicaçăo de $\mathrm{H}_{2} \mathrm{CN}_{2}$ em gemas de videira resulta na reduçăo da atividade da catalase, que baixa de 26 para 15 unidades grama-1 $\times 10^{-1}$, enquanto que a atividade da peroxidase permanece inalterada. A manutençăo de videiras à temperatura de $4^{\circ} \mathrm{C}$ para induzir a brotação resultou também em uma marcada redução da atividade da catalase sem afetar a atividade da peroxidase. É sugerido que $\mathrm{H}_{2} \mathrm{CN}_{2}$ ou baixa temperatura estão envolvidas no término do repouso por reduzir a atividade da catalase.

A atividade da catalase em gemas do cultivar Perlette, cultivado no vale do Rio Jordăo, Israel, foi monitorada do outono até a primavera. Sua atividade aumentou marcadamente no outono, alcançando um máximo no final de outubro, quando entáo começou a decrescer, alcançando um mínimo em janeiro. A atividade da catalase e a intensidade da dormência começou a diminuir paralelamente à queda da temperatura. Esses resultados podem explicar os efeitos inibidores de altas temperaturas durante o inverno na quebra de dormencia. Frio artificial a $5^{\circ} \mathrm{C}$ resultou em um decréscimo de $25 \%$ na atividade da catalase nas gemas após 3 dias e $31 \%$ após 17 dias. Eficientes agentes indutores de quebra de dorméncia como a tiouréia e cianamida diminuiram a atividade da catalase em 64 e 50\% respectivamente quando comparado ao controle não tratado, enquanto que a atividade da peroxidase permaneceu a mesma sob as mesmas condições. Um agente menos eficiente na quebra de dormência como o dinitro-orto-cresol, não diminuiu a atividade da catalase. Deste modo, a intensidade de dorméncia em gemas de videira é positivamente relacionada à atividade da catalase. A atividade da catalase diminui pelas baixas temperaturas de inverno e agentes químicos de quebra de dormência, tais como cianamida e tiouréia. É possivel, como previamente sugerido para sementes, e comprovado também em gemas de videira, que a redução da atividade da catalase cause um aumento no nível de $\mathrm{H}_{2} \mathrm{O}_{2}$ no tecido da gema, que pode ativar o caminho da pentose-fosfato, levando à quebra da dormência, brotação das gemas e rápido crescimento (NIR et al., 1986).

PONI et al. (1990) observaram o efeito da cianamida hidrogenada em vinhedo de 'Sangiovese' situado em regiões de inverno gelado como o vale do Rio Pó. Os tratamentos consistiram de: controle (não tratado), 
cianamida hidrogenada $1 \%$ ou $2 \%$, aplicados em meados do mês de março. Os tratamentos com $\mathrm{H}_{2} \mathrm{CN}_{2}$ anteciparam a brotação em 8 e 4 dias, respectivamente, comparados ao controle. As plantas tratadas também brotaram mais rápido. Entretanto esses efeitos foram diluïdos durante o desenvolvimento fenológico, e no final do experimento todas as plantas apresentavam o mesmo desenvolvimento vegetativo. $O$ ciclo das plantas e a produção por planta não foram afetados pelos tratamentos.

As uvas de mesa cultivadas em regiões desérticas estão submetidas a um estreito periodo de baixas temperaturas durante a dorméncia, com alta oscilação entre as temperaturas diurnas e noturnas. Nestas situaçōes, o acúmulo de horas de frio e a brotação das gemas são influenciadas nos cultivares precoces. OSÓRIO et al. (1993), submeteram a videira Flame Seedless' a tratamentos contínuos ou interrompidos à temperatura de $4^{\circ} \mathrm{C}$ por 100,200 ou 300 horas, tratando ou não com cianamida $0,1 \mathrm{M}$. As interrupçóes ocorreram após 100 ou 200 horas de frio por 2,4 ou 6 dias a temperaturas de 20 ou $25^{\circ} \mathrm{C}$. Intervalos em altas temperaturas afetaram muito mais negativamente a quebra de dormência das gemas das plantas tratadas com cianamida do que as não tratadas, independentemente da temperatura. A brotação foi precoce e rápida em plantas que receberam 200 horas de frio e foram submetidas à temperatura de $20^{\circ} \mathrm{C}$ por 2 dias, ou 4 a 6 dias a $25^{\circ} \mathrm{C}$ e sem receberem aplicação de cianamida. Com aplicação de cianamida, e interrupção após 200 horas de frio e submetidas a 2,4 ou 6 dias à temperatura de $20^{\circ} \mathrm{C}$ houve redução e atraso na brotação. Interrupção do frio por 2 dias, a $25^{\circ} \mathrm{C}$, e sem aplicação de cianamida em plantas que receberam 200 horas de frio, o estímulo à quebra de dormencia foi negativo, enquanto que a 4 ou 6 dias de intervalo a temperatura elevada estimulou a brotaçắo.

O escasso acúmulo de horas de frio durante o outono e a alta variabilidade durante os anos sob condiçóes de deserto demanda estudos prioritários sobre a interação entre acúmulo de horas de frio e dose de cianamida hidrogenada para melhorar a quebra de dormência de gemas de videira. SILLER-CEPEDA et al. (1993) coletaram estacas de videira 'Flame Seedless' e armazenaram a $4^{\circ} \mathrm{C}$ por 0 a 300 horas. Adicionalmente, pulverizaram cianamida a 0,$0 ; 0,025 ; 0,050,0,100 ; 0,200$ e $0,400 \mathrm{M}$ a cada 50 horas de frio (HF), e as estacas eram levadas à camara de crescimento $\left(23+1{ }^{\circ} \mathrm{C}\right)$ e luz artificial para avaliações sobre a quebra de dormência. Os resultados obtidos foram: as 
estacas controle apresentaram $12 \%$ de brotação enquanto as que receberam $300 \mathrm{HF}$ apresentaram $96 \%$; obtiveram $66 \%$ de brotaçăo para as que receberam $250 \mathrm{HF}$. Doses de cianamida maiores ou iguais a $0,2 \mathrm{M}$ induziram a quebra de dormencia e foram superiores ao controle em estacas que receberam frio menor ou igual a $250 \mathrm{HF}$. Após $300 \mathrm{HF}$, as estacas não tratadas com cianamida brotaram normalmente, enquanto as que receberam cianamida tiveram sua brotaçăo atrasada. Os melhores tratamentos com cianamida foram 0,1 a $0,2 \mathrm{M}$. No final da brotação não foram encontradas diferenças significativas entre os tratamentos com cianamida em estacas que receberam $300 \mathrm{HF}$; entretanto entre 100 e $200 \mathrm{HF}$ a cianamida induziu uma brotaçăo precoce.

BRACHO et al. (1984) verificaram o efeito da cianamida hidrogenada $(0 ; 0,63 ; 1,25 ; 2 ; 2,5 ; 3 ; 4$ e $6 \%)$ na variedade de uva Cabernet Sauvignon cultivada em Davis e Oakville, Califórnia. Os resultados de ambos experimentos, mostraram claramente que a cianamida hidrogenada promoveu uma uniforme quebra de dormência. $\mathrm{H}_{2} \mathrm{CN}_{2} \quad 1,25 \%$ foi levemente superior na indução de brotação das gemas localizadas nas partes médias e basais das varas das videiras cultivadas em Davis do que em Oakville. As diferenças na brotação podem ter ocorrido devido à diferença no acúmulo de horas de frio pela planta verificada entre as duas regiōes, uma vez que Davis é mais frio que Oakville. Os efeitos da cianamida como agente indutor de brotaçăo é importante para as regiões estudadas uma vez que em condições naturais, as gemas localizadas nas partes médias e basais das varas não brotam. Os autores concluíram que para a região de Oakville as concentrações de 2 e $3 \%$ foram mais eficientes, enquanto que em Davis a melhor dose foi 1,25\%. Em Davis, a cianamida na dose de $6 \%$ acarretou atraso na brotação e danos nas gemas.

JENSEN \& BETTIGA (1984) concluiram que a cianamida hidrogenada $2,5 \%$ aplicada após a poda realizada na primavera, nas variedades Thompson Seedless, Emperor e French Colombard, em vinhedos localizados em Parlier, California, não influenciaram na quebra de dormência das gemas e nem na precocidade ou uniformidade da brotação. Pelo contrário, em Thompson Seedless a brotação foi atrasada e reduzida com a dose aplicada.

LUVISI (1984) avaliou a possibilidade de uso da cianamida hidrogenada na região de Kern County, Califórnia, com o objetivo de verificar sua eficácia na quebra de dormência e produtividade da videira. Pulverizou $\mathrm{H}_{2} \mathrm{CN}_{2} 2,5 \%$ imediatamente após a poda nas variedades Perlette, Flame 
Seedless e Thompson Seedless em très épocas de poda: 18 de janeiro, $1^{\circ}$ e 17 de fevereiro. Nos experimentos, as videiras podadas em janeiro e no inicio de fevereiro tenderam a antecipar a brotação e ter mais brotos em desenvolvimento ao longo das varas. As videiras podadas na segunda quinzena de fevereiro, tenderam a atrasar a brotação e a desenvolver menor vegetação ao longo da vara. Em todos os experimentos não foram verificados redução do ciclo, aumento da produtividade, alteração na relação açúcar/acidez, com o emprego ou não da cianamida hidrogenada.

WHITING \& COOMBE (1984) pesquisando a resposta das videiras Sultana e Cabernet Sauvignon à cianamida em vinhedos localizados na regiâo de Vitória, Austrália. Pulverizaram $\mathrm{H}_{2} \mathrm{CN}_{2} 0,83 \mathrm{M}$ nas varas das videiras imediatamente após a poda. Concluíram que, em contraste com o citado em outros trabalhos sobre cianamida, não houve evidência na precocidade de brotação e sim um significativo decréscimo na porcentagem de gemas brotadas e desenvolvimento de ramos ao longo das varas. A baixa porcentagem de brotação nas plantas das duas variedades tratadas com cianamida pode ser atribuida pela morte das gemas. Os autores acreditam que a quebra da dormência de gemas de videira pode ser influenciada pela época de aplicação e a concentração de cianamida, visto que, em trabalhos preliminares, verificaram que $\mathrm{H}_{2} \mathrm{CN}_{2} \mathrm{O}, 25 \mathrm{M}$ a $0,60 \mathrm{M}$ (isto e, $1 \%-2,5 \%$ ) năo provocaram morte de gemas e promoveram uma boa brotação e distribuição de ramos ao longo da vara.

WICKS et al. (1984) estudaram a indução à precocidade e uniformidade de brotação através do uso da cianamida hidrogenada nos cultivares de videira Perlette, Flame Seedless e Thompson Seedless, em vinhedos comerciais, localizados em Coachella Valley, Califórnia. Pulverizaram $\mathrm{H}_{2} \mathrm{CN}_{2} \mathrm{O}, 1,25$ e $2,5 \%$ imediatamente após as podas sucessivas realizadas semanalmente de 22 de dezembro de 1983 a 2 de janeiro de 1984 em Perlette e Flame, e 28 de dezembro de 1983 a 25 de janeiro de 1984 em Thompson Seedless. Com base nos resultados deste e de outros experimentos, os autores afirmam que a cianamida hidrogenada tornar-se-á uma útil ferramenta na viticultura mundial. Ela pode ser usada nos trópicos e nas regiões desérticas do mundo. Nas regiões temperadas, com inverno frio, o aumento na uniformidade da brotação das gemas, em certas situações e com certas variedades, provou ser muito benéfico. 
LIN \& WANG (1985) estudaram o efeito da cianamida na quebra de dormencia de gemas de estacas isoladas de videira 'Kyoho' em dois experimentos. No experimento I, utilizaram estacas com um ano de idade provenientes de cultura de tecidos, e cianamida nas concentraçóes de $1,0 \%$ e $2,5 \%$; no experimento II utilizaram estacas provenientes de vinhedo comercial com 10 anos de idade. Em ambos experimentos a concentração de $1 \%$ mostrouse efetiva na quebra de dormência das gemas da videira. As taxas de gemas brotadas nos experimentos I e II foram $58 \%$ e $27 \%$ respectivamente, enquanto que nas estacas não tratadas a porcentagem de gemas abertas foi de $3,3 \%$ e $0 \%$ respectivamente. No experimento I na concentraçăo de $2,5 \%$ a porcentagem de gemas abertas foi de $9,7 \%$, entretanto os autores não mencionaram se as gemas nåo brotadas estavam vivas ou mortas.

Verificou-se 0 efeito da cianamida hidrogenada sobre a brotação e a produção em vinhedos da região de Bordeaux. $\mathrm{H}_{2} \mathrm{CN}_{2} 5 \%$ foi aplicada em 15 de fevereiro no cultivar Cabernet Sauvignon enxertado no portaenxerto SO 4 em varas podadas com 6,12 ou 18 gemas. $O$ tratamento aumentou a porcentagem de brotação das gemas e proporcionou a uniformidade dos brotos ao longo da vara e, na mesma gema latente induziu a brotação da gema primária e secundária. As plantas tratadas produziram $4460 \mathrm{~g} /$ planta e as não tratadas (controle) produziram 4020g/planta (CASTERAN, 1987).

A cianamida hidrogenada é usada em áreas onde 0 acúmulo de horas de frio é insuficiente para promover uma elevada e uniforme brotação de gemas de videira. Ela foi usada em três vinhedos em Edna Valley, região de San Luis Obispo, Califórnia, para determinar se aumentaria a brotação em áreas mais frias. Após a poda, 'Chardonnay', 'Cabernet Sauvignon e 'Zinfandel' foram pulverizadas com cianamida hidrogenada 2,5\%. Ocorreu uma brotação precoce nas videiras 'Cabernet Franc' tratadas, mas não houve diferenças no final da brotaçăo. A brotaçăo em 'Chardonnay' também foi mais precoce nas plantas tratadas, e no final da brotação as videiras tratadas apresentaram muito mais gemas brotadas que as não tratadas (controle). Não houve diferenças notórias em Zinfandel. $O$ rendimento e a qualidade do fruto foram superiores nas plantas tratadas de 'Cabernet Sauvignon' e 'Chardonnay', enquanto que nenhuma diferença significativa foi apresentada por 'Zinfandel' (FOOT, 1987). 
ZELLEKE \& KLIEWER (1989) estudaram os efeitos da cianamida hidrogenada no aumento de brotaçăo em diversos cultivares de videira em vinhedos jovens, em Davis, California. Plantas dormentes de 'Thompson Seedless' e 'Cabernet Sauvignon' com 2 e 4 anos respectivamente, e 'Grenache' com 2, 3 e 4 anos foram pulverizadas com $\mathrm{H}_{2} \mathrm{CN}_{2} 1$ ou $2 \%$ um dia após a poda. Verificaram que ambas concentrações de cianamida na variedade Grenache com 3 e 4 anos, induziram uma quebra de dormência precoce, conferindo uma brotação uniforme ao longo da vara, inclusive nas partes basais; entretanto, na de 2 anos, $\mathrm{H}_{2} \mathrm{CN}_{2} 1 \%$ foi mais efetiva. Para 'Thompson Seedless' e 'Cabernet Sauvignon' $\mathrm{H}_{2} \mathrm{CN}_{2} 2 \%$ foi mais efetiva na antecipação e uniformização da brotação ao longo da vara, inclusive no terço basal que normalmente apresenta dificuldade de brotaçăo.

MURISIER et al. (1990), em Nyon, Suiça, pesquisaram a ação da cianamida hidrogenada a $2,5 \%$ e $5,0 \%$ sobre a videira Merlot podada em diferentes épocas. Concluíram que a cianamida hidrogenada em ambas as concentraçōes, melhorou a quebra de dormência das gemas e uniformizou a brotação, e com isso facilitou a condução dos brotos e os tratamentos fitossanitários na primavera. Os autores não mencionaram problemas de fitotoxicidade em nenhuma das concentrações utilizadas.

No Rio Grande do Sul, a pulverizaçăo de cianamida hidrogenada em varas de videira 'Cabernet Sauvignon' por ocasião da poda seca, nas concentraçőes de $0,1,3$ e $5 \%$, teve um efeito significativo sobre as variáveis porcentagem de gemas brotadas, número de cachos por planta, fertilidade por gema e produtividade por gema e do vinhedo. $A$ análise de regressão polinomial mostrou que houve um efeito quadrático significativo, e que os pontos de máximo para estas variáveis foram obtidos com concentrações entre $1,8 \%$ e $1,9 \%$. Entretanto, ela não teve efeito significativo sobre peso do cacho, peso da baga e produtividade por gema brotada, nem sobre o teor de sólidos solúveis, acidez total, açúcar/acidez total, $\mathrm{pH}$, densidade, $\mathrm{P}, \mathrm{K}, \mathrm{Ca}$ e $\mathrm{Mg}$ do mosto da uva. Quando comparada com a testemunha, a aplicação de cianamida hidrogenada a $1 \%$ antecipou a brotação em quatro dias; na concentração de $5 \%$, retardou-a em 18 dias. Ela também uniformizou e diminuiu ou suprimiu a domináncia apical (MIELE, 1991).

SILLER-CEPEDA et al (1994) em Sonora, México, estudaram a quebra de dormência de gemas da videira. 'Perlette' em diferentes 
estádios de desenvolvimento. As videiras foram podadas em 16 de novembro, 2 de dezembro e 16 de dezembro. A cianamida hidrogenada foi aplicada imediatamente, 5,10 e 15 dias após a poda, em concentrações que variaram entre $0 \%, 1 \%, 2 \%, 4 \%, 6 \%$ e $8 \%$ de ingrediente ativo. Foram avaliados porcentagem de gemas brotadas, número de cachos e rendimento por planta, e a colheita foi realizada quando os frutos apresentavam $15^{\circ}$ a $16^{\circ}$ Brix. Em geral as plantas tratadas com cianamida apresentaram porcentagem de brotação variando entre $50 \%$ a $85 \%$. Não foi verificada fitotoxicidade nas doses mais elevadas, entretanto, após 14 de dezembro todas as concentrações tenderam a reduzir e atrasar a quebra de dormência. Aplicação de cianamida 5, 10 e 15 dias após a poda retardou a brotação em cinco dias quando comparado com o tratamento aplicado imediatamente após a poda. As videiras podadas e pulverizadas na endodormência ( 2 de dezembro) com cianamida $8 \%$ adiantaram em um mês a colheita e produziram $12 \mathrm{~kg}$ por planta. 


\section{MATERIAL E MÉTODOS}

\subsection{MATERIAL}

\subsubsection{Cultivar copa}

Foi utilizado o cultivar 'Niagara Rosada', mutação somática natural ocorrida em Jundiai em 1933, da variedade americana 'Niagara' (Vitis labrusca L. $x$ Vitis vinifera L.), de bagas brancas.

É o cultivar de uva rústica mais plantado no Estado de São Paulo, com área cultivada de aproximadamente 6.500 ha. Sua produtividade média é de $1,25 \mathrm{~kg} / \mathrm{m}^{2}$. Pode ser conduzido nos sistemas de espaldeira ou latada, com poda variando de 1 a 5 gemas.

Apresenta excelente resistência às moléstias criptogåmicas, principalmente ao oídio, causado pelo patógeno Uncinula necator (Schw.) Burril, (Oidium tuckerii Berk.), e em menor escala ao mildio, causado pelo patógeno Plasmopara viticola (Berk. \& Curt.) Berl. \& de Toni; é medianamente suscetivel à antracnose, causada pelo patógeno Elsinoe ampelina (de Bary), Shear (Sphaceloma ampelinum de Bary) (GALLl et al., 1968)

A planta é de vigor médio, produtiva. Seus cachos aparecem opostos a partir da $3^{a}$ ou $4^{a}$ gemas do ramo produtivo, são de tamanho médio, cónicos e compactos, com baixa resisténcia ao transporte e ao armazenamento prolongado, devido à fraca aderência das bagas ao pedicelo. As bagas são de cor rosada, tamanho médio, de forma ovalada, sucosa e com muita pruina; de sabor foxado, não racham, nem apodrecem com chuvas prolongadas no período de colheita, permanecendo em perfeitas condições na planta (POMMER et al., 1994) 


\subsubsection{Cultivares porta-enxertos}

\subsubsection{Ripária do Traviú}

Trata-se do $V$. riparia $-V$. rupestris $\times V$. cordifolia (106-8 Mgt), também conhecido simplesmente como Traviú.

Foi o mais recomendado para Niagara, motivo que o levou a ser o porta-enxerto mais difundido no Estado de São Paulo. De bom desenvolvimento, porém sem muito vigor, adapta-se bem a muitos tipos de solos paulistas. Suas estacas apresentam ótimo pegamento, mas é suscetivel à antracnose, necessitando de tratos fitossanitários durante o desenvolvimento vegetativo (TERRA et al., 1993)

\subsubsection{IAC 766 Campinas}

Cruzamento do porta-enxerto Ripária do Traviú com a espécie de videira tropical Vitis caribæa realizado por Santos Neto, em 1958.

É vigoroso, apresenta perfeita adaptação às condições ambientais paulistas; suas folhas săo bastante resistentes às doenças, e suas estacas apresentam bom indice de pegamento (TERRA et el., 1993).

\subsubsection{Compostos químicos utilizados}

Os compostos químicos utilizados foram: calciocianamida, cianamida hidrogenada, nitrato de potássio e nitrato de cálcio.

\subsubsection{Calciocianamida}

Nome: calciocianamida

Fórmula empírica: $\mathrm{CaCN} 2$

Fórmula estrutural: $\mathrm{Ca}=\mathrm{N}-\mathrm{C} \equiv \mathrm{N}$

Teor de nitrogénio: $20 \%$

Teor de CaO: $55 \%$

Teor de Cianamida: $21 \%$

Nome comercial: Calciocianamida 


\subsubsection{Cianamida hidrogenada}

Sua descrição é a seguinte:

Nome: cianamida hidrogenada

Fórmula empírica: $\mathrm{H}_{2} \mathrm{CN}_{2}$

Fórmula estrutural:

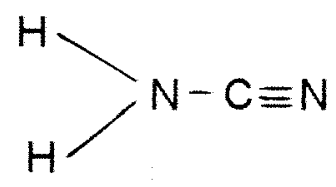

Teor de nitrogênio: $66 \%$

Teor do principio ativo: $49 \%$

Formulação: formulação aquosa especialmente estabilizada

Nome comercial: Dormex $(\mathbb{R}$

\subsubsection{Nitrato de potássio (p.a.)}

Fórmula empírica: $\mathrm{KNO}_{3}$

$P M=101,10 \mathrm{~g} / \mathrm{mol}$

\subsubsection{Nitrato de cálcio (p.a.)}

Fórmula empírica: $\mathrm{Ca}\left(\mathrm{NO}_{3}\right)_{2}$

$P M=236,15 \mathrm{~g} / \mathrm{mol}$

\subsection{Métodos}

Os experimentos foram realizados em vinhedos comerciais nas regiōes viticolas mais importantes do Estado de São Paulo representadas pelos municípios de Jundiaí, Indaiatuba e São Miguel Arcanjo.

\subsubsection{Região de Jundiaí}

A região, do ponto de vista climático, apresenta-se classificada como Cfa de acordo com o sistema proposto por Koeppen (SETZER, 1966), e os dados de temperatura e precipitação nos anos de 1992 e 1993 são apresentados no APÊNDICE (Tabelas 1 e 2).

Os experimentos foram realizados no ciclo vegetativo 19921993, em vinhedos comerciais de propriedade de Carbonari e Caniato, localizados no Bairro do Poste, município de Jundiaí, Estado de São Paulo, 
situado a $23^{\circ} 06^{\prime} \mathrm{S}$ e a $46^{\circ} 55^{\prime} \mathrm{W}$ e $715 \mathrm{~m}$ de altitude, em latossolo vermelhoamarelo.

As videiras em estudo estavam com seis anos de idade em 1992 e enxertadas sobre o porta enxerto 'Ripária do Traviú' (106-8 Mgt). Essas videiras estavam plantadas no espaçamento $2 \times 1 \mathrm{~m}$, sendo conduzidas no sistema de espaldeira com três fios de arame, poda de produção em cordão esporonado, com os esporões contendo uma gema e a coroa.

Foram conduzidos dois experimentos, sendo um comparando a ação da cianamida hidrogenada $\left(\mathrm{H}_{2} \mathrm{CN}_{2}\right)$ com a calciocianamida $\left(\mathrm{CaCN}_{2}\right)$ em dez podas semanais consecutivas, de 13/07/92 a 14/09/92 (experimento 1), e outro em uma só época de poda, realizada em 27/07/92, utilizando doses crescentes de $\mathrm{H}_{2} \mathrm{CN}_{2}$ (experimento 2).

Os compostos químicos foram aplicados imediatamente após a poda seca, quando as gemas estavam dormentes, isto é, durante o estádio A de Baggiolini (BAGGIOLINI, 1952). A aplicação dos compostos químicos foi feita sempre no período da manhã.

No experimento 1,0 delineamento experimental adotado foi o de blocos ao acașo, com parcelas subdivididas, sendo as parcelas principais constituídas de 10 épocas de poda, e as sub-parcelas constituídas de seis tratamentos repetidos cinco vezes, sendo cada subparcela constituída por uma planta, na qual foram marcados seis esporões.

Os tratamentos consistiram do seguinte: controle não tratado; soluções aquosas de $\mathrm{H}_{2} \mathrm{CN}_{2}$ a $1 \%, 2 \%, 3 \%, 4 \%$ aplicadas em pulverização total do cordão esporonado, e suspensão de $\mathrm{CaCN}_{2} 20 \%$, aplicada em pincelamento nas gemas e nos cortes da poda.

Foram avaliadas as seguintes variáveis nos esporões marcados: número de dias para a brotação, porcentagem de brotação (quantidade de gemas marcadas brotadas), ciclo (período compreendido entre a poda e a colheita, contado em dias), número de cachos, peso médio dos cachos (g) e peso dos cachos por planta $(\mathrm{kg})$, que é a produção por planta.

Os dados de brotação foram transformados em arc sen $\sqrt{x+0,5}$, e os demais dados foram transformados em $\sqrt{x+0,5}$.

Foram estudados os efeitos de tratamentos dentro das épocas. Para a comparação das médias empregou-se o teste de Tukey ao nível de $5 \%$ de probabilidade. 
No experimento 2, o delineamento estatistico empregado foi o de blocos ao acaso, com seis tratamentos, cinco repetiçóes, sendo cada parcela constituída por uma planta, na qual foram marcados seis esporões.

Os tratamentos consistiram da aplicação, feita através da pulverização total do cordão esporonado, de soluções aquosas de $\mathrm{H}_{2} \mathrm{CN}_{2}$ nas concentrações de $0,0 \% ; 1.0 \% ; 1,25 \% ; 1,5 \% ; 1,75 \% ; 2,0 \%$.

As variáveis avaliadas foram as mesmas estudadas no experimento 1.

Os dados de porcentagem de brotação foram transformados em $\sqrt{x+0,5}$, e os demais dados em $\sqrt{x}$.

Os tratamentos que apresentaram resultados significativos foram estudados através de regressåo polinomial.

\subsubsection{Região de Indaiatuba}

A região, do ponto de vista climático, apresenta-se classificada como Cwa de acordo com o sistema proposto por Koeppen (SETZER, 1966), cujos dados de temperatura e precipitação são apresentados no APÊNDICE (Tabela 3).

Os experimentos foram efetuados no ciclo vegetativo 19931994, em vinhedos comerciais de propriedade de Secco, localizados no Bairro das Videiras, Municipio de Indaiatuba, Estado de São Paulo, situado a 23005'S e a $47^{\circ} 13^{\prime} \mathrm{W}$, e $630 \mathrm{~m}$ de altitude, em solo podzolizado com cascalhos.

As videiras em estudo estavam com 11 anos de idade em 1993 no experimento 1, e 4 anos de idade nesse mesmo ano no experimento 2 e enxertadas sobre o porta-enxerto 'Ripária do Traviú' (106-8 Mgt). Essas videiras estavam plantadas no espaçamento de $2 \times 1 \mathrm{~m}$, sendo conduzidas no sistema de espaldeira com três fios de arame, poda de produção em cordão esporonado, com os esporóes contendo uma gema e a coroa.

Foram conduzidos dois experimentos, sendo o primeiro comparando a ação da calciocianamida, da cianamida hidrogenada, do nitrato de potássio $\left(\mathrm{KNO}_{3}\right)$ mais nitrato de cálcio $\left[\mathrm{Ca}\left(\mathrm{NO}_{3}\right)_{2}\right]$ isoladamente ou adicionados à calciocianamida e à cianamida hidrogenada (experimento 1), e o segundo comparando doses crescentes de cianamida isoladamente e comparadas com calciocianamida. Nos dois experimentos as videiras foram podadas em 06/08/1993. 
Os compostos químicos foram aplicados imediatamente após a poda seca, quando as gemas estavam dormentes, isto é, durante o estádio $A$ de Baggiolini. A aplicação desses compostos foi feita sempre no período da manhă.

No experimento 1,0 delineamento estatístico foi o de blocos ao acaso, com doze tratamentos, cinco repetições, sendo cada parcela constituída por uma planta, na qual foram marcados seis esporões.

Os tratamentos consistiram do seguinte: 1) controle não tratado, 2) $\mathrm{H}_{2} \mathrm{CN}_{2} 1 \%$, 3) $\mathrm{H}_{2} \mathrm{CN}_{2} 1,25 \%$, 4) $\mathrm{H}_{2} \mathrm{CN}_{2} 1,5 \%$, 5) $\mathrm{H}_{2} \mathrm{CN}_{2} 1,75 \%$, 6) $\left.\left.\left.\mathrm{H}_{2} \mathrm{CN}_{2} 2,0 \%, 7\right) \mathrm{CaCN}_{2} 20 \%, 8\right) \mathrm{Ca}\left(\mathrm{NO}_{3}\right)_{2} 5 \%+\mathrm{KNO}_{3} 5 \%, 9\right) \mathrm{Ca}\left(\mathrm{NO}_{3}\right)_{2} 5 \%+$ $\left.\mathrm{KNO}_{3} 5 \%+\mathrm{H}_{2} \mathrm{CN}_{2} 0,25 \%, 10\right) \mathrm{H}_{2} \mathrm{CN}_{2} \mathrm{O}, 25 \%$, 11) $\mathrm{Ca}\left(\mathrm{NO}_{3}\right)_{2} 5 \%+\mathrm{KNO}_{3} 5 \%$ $+\mathrm{CaCN}_{2} 5 \%$, 12) $\mathrm{CaCN}_{2} 5 \%$. À exceção da suspensão de $\mathrm{CaCN}_{2} 20 \%$ que foi aplicada por pincelamento nas gemas e cortes da poda, os demais tratamentos foram aplicados em pulverização total do cordão esporonado.

Foram avaliadas as seguintes variáveis nos esporões marcados: número de dias para a brotação, porcentagem de brotação, ciclo (periodo compreendido entre a poda e a colheita), número de cachos, peso médio dos cachos $(\mathrm{g})$ e peso dos cachos por planta $(\mathrm{kg})$, que é a produção por planta.

Os dados de porcentagem de brotaçắo foram transformados em arc sen $\sqrt{x}$, e os demais dados em $\sqrt{x}$.

Para a comparação das médias empregou-se o teste de Tukey ao nivel de $5 \%$ de probabilidade.

No experimento 2 foram realizadas duas análises de variância, uma levando em conta todos os tratamentos [Análise de Variância 1 (A.1)], e outra excluindo o tratamento com calciocianamida [Análise de Variância 2 (A.2)].

Na primeira análise de variância, o delineamento estatistico empregado foi o de blocos ao acaso, com sete tratamentos, cinco repetições, sendo cada parcela constituída por uma planta, na qual foram marcados seis esporões.

Os tratamentos foram os seguintes: 1) Controle não tratado, 2) $\mathrm{H}_{2} \mathrm{CN}_{2} 1,0 \%$, 3) $\mathrm{H}_{2} \mathrm{CN}_{2} 1,25 \%$, 4) $\mathrm{H}_{2} \mathrm{CN}_{2} 1,5 \%$ 5) $\mathrm{H}_{2} \mathrm{CN}_{2} 1,75 \%$ 6) $\mathrm{H}_{2} \mathrm{CN}_{2}$ $2,0 \%, 7) \mathrm{CaCN}_{2} 20 \%$. À exceção da suspensão de CaCN2 $20 \%$ que foi aplicada 
por pincelamento nas gemas e cortes de poda, os demais tratamentos foram aplicados em pulverização total do cordăo esporonado.

As variáveis avaliadas e as transformações dos dados foram as mesmas utilizadas no experimento 1 .

Para a comparação das médias empregou-se o teste de Tukey ao nivel de $5 \%$ de probabilidade.

$\mathrm{Na}$ segunda análise de variância, o delineamento estatístico empregado foi o de blocos ao acaso, com seis tratamentos, cinco repetições, sendo cada parcela constituída por uma planta, na qual foram marcados seis esporöes.

Os tratamentos consistiram da aplicação, feita através da pulverizaçåo total do cordåo esporonado, de soluçóes aquosas de $\mathrm{H}_{2} \mathrm{CN}_{2}$ nas concentrações de $0,0 \% ; 1,0 \% ; 1,25 \% ; 1,5 \% ; 1,75 \% ; 2,0 \%$.

As variáveis avaliadas e as transformações dos dados foram os mesmas utilizadas no experimento 1 .

Os tratamentos que apresentaram resultados significativos foram estudados através de regressão polinomial.

\subsubsection{Região de São Miguel Arcanjo}

A regiâo, do ponto de vista climático, apresenta-se classificada como Cfa de acordo com o sistema proposto por Koeppen (SETZER, 1966), cujos dados de temperatura e precipitação estão contidos no APENNDICE (Figuras 4,5 e 6).

Os dois experimentos foram realizados nos ciclos vegetativos 1991-1992 e 1992-1993, em vinhedos comerciais de propriedade de Tomazeto, localizados no Bairro do Gramadão, Municipio de São Miguel Arcanjo, situado a 23052 'S e a $48^{\circ} 00 \mathrm{~W}$ e $650 \mathrm{~m}$ de altitude, em latossolo vermelho-amarelo.

As videiras estavam com 4 anos de idade enxertadas sobre o porta enxerto IAC 766 'Campinas'. Essas videiras estavam no espaçamento $2 \times 1,5 \mathrm{~m}$, sendo conduzidas no sistema de espaldeira com três fios de arame, poda de produção em cordão esporonado, com os esporões contendo uma gema e a coroa.

Foi conduzido um experimento por ano comparando a ação de doses crescentes de cianamida com calciocianamida, ou comparando 
somente as doses crescentes de cianamida hidrogenada. Em ambos os anos, não foi possivel fazer uso de tratamento testemunha. Devido as plantas selecionadas para esse fim não terem apresentado brotação de gemas 15 dias após a poda, foi aplicada calciocianamida $20 \%$ para estimular a brotaçăo das gemas para que o vinhedo não ficasse com plantas possivelmente danificadas.

No experimento 1 , podado em $13 / 08 / 91$, foram realizadas duas análises de variância, uma levando em conta todos os tratamentos [Análise de Variância 1 (A.1)], e outra excluindo o tratamento com calciocianamida [Análise de Variância 2 (A.2)].

Na primeira análise de variância, o delineamento estatisțico empregado foi o de blocos ao acaso, com sete tratamentos, cinco repetições, sendo cada parcela constituida por uma planta, na qual foram marcados seis esporões.

Os tratamentos foram os seguintes: $\mathrm{H}_{2} \mathrm{CN}_{2} 1 \% ; 2 \% ; 3 \%$; $4 \% ; 5 \% ; 6 \%$ e $\mathrm{CaCN}_{2} 20 \%$. À exceção da suspensão de $\mathrm{CaCN}_{2} 20 \%$ que foi aplicada em pincelamento nas gemas e cortes dos ramos podados, os demais tratamentos foram aplicados em pulverização total do cordão esporonado.

As variáveis estudadas foram: porcentagem de brotaçăo da gema principal, porcentagem de brotação de gemas velhas, porcentagem de brotação total, número de cachos, peso por cacho em grama, produçăo em quilograma.

Os dados de porcentagem foram transformados em arc sen $\sqrt{x}$ e os demais dados em $\sqrt{x}$.

Para a comparação das médias empregou-se o teste de Tukey ao nivel de $5 \%$ de probabilidade.

$\mathrm{Na}$ segunda análise de variância, o delineamento estatístico empregado foi o de blocos ao acaso, com seis tratamentos, cinco repetições, sendo cada parcela constituída por uma planta, na qual foram marcados seis esporões.

Os tratamentos consistiram da aplicação, feita através da pulverização total do cordão esporonado, de soluções aquosas de $\mathrm{H}_{2} \mathrm{CN}_{2}$ nas concentrações de $1 \% ; 2 \% ; 3 \% ; 4 \% ; 5 \% ; 6 \%$.

As variaveis avaliadas e as transformações dos dados foram os mesmas utilizadas na primeira análise de variância. 
Os tratamentos que apresentaram resultados significativos foram estudados através de regressão polinomial.

Os tratamentos que apresentaram resultados estatisticamente significativos foram estudados através de regressăo polinomial.

No segundo experimento (experimento 2), podado em $13 / 08 / 92$, o delineamento estatístico empregado foi o de blocos ao acaso, com cinco tratamentos, cinco repetições, sendo cada parcela constituída por uma planta, na qual foram marcados seis esporöes.

Os tratamentos consistiram da aplicação, feita através da pulverização total do cordăo esporonado, de soluçóes aquosas de $\mathrm{H}_{2} \mathrm{CN}_{2}$ nas doses de $1,0 \% ; 1,25 \%: 1,5 \% ; 1,75 \% ; 2,0 \%$.

As variáveis utilizadas e as transformaçס̌es dos dados foram as mesmas utilizadas no experimento 1.

Os tratamentos que apresentaram resultados estatísticos significativos foram estudados através de regressão polinomial.

Em todos os experimentos conduzidos nas três regióes, os demais tratos culturais das videiras, como tratamento de inverno, tratamento fitossanitário, amarraçăo dos brotos, desnetamento, desbrota, foram realizados de acordo com a recomendação de PIRES \& TERRA (1987). 


\section{RESULTADOS E DISCUSSÃO}

\subsection{Região de Jundiaí}

\subsubsection{Experimento 1}

Este experimento procurou investigar 0 efeito dos tratamentos testemunha, $\mathrm{H}_{2} \mathrm{CN}_{2} 1 \%, \mathrm{H}_{2} \mathrm{CN}_{2} 2 \%, \mathrm{H}_{2} \mathrm{CN}_{2} 3 \%, \mathrm{H}_{2} \mathrm{CN}_{2} 4 \%$ e $\mathrm{CaCN}_{2} 20 \%$ em diferentes épocas de poda. A tabela 1 mostra que houve, do ponto de vista estatístico, diferença altamente significativa para o parâmetro dias para brotar.

A tabela 2 apresenta a comparaçăo pelo teste de Tukey dos tratamentos dentro das diferentes épocas de poda.

Tabela 1. Análise de variancia relativa aos dados de
dias para brotar. Experimento 1. Jundiai.
1992 .

\begin{tabular}{lrrrr}
\hline Causas da variação & GI & QH & Valor F & P $>F$ \\
\hline Bloco & 4 & & & \\
Epoca & 9 & 11.8641 & 248,42 & 0.01 \\
Residuo (A) & 36 & 0.0477 & & \\
& & & & \\
\hline Parcelas & 49 & & & \\
Tratamentos & 5 & 45.2962 & 618.74 & 0.01 \\
Epoca x Tratamento & 45 & 2.6639 & 36.38 & 0.01 \\
Residuo (B) & 200 & 0.0732 & &
\end{tabular}

Média Geral: 4,72

C. V. $(A)=1.8 \%$

C. V. $(B)=5,7 \%$ 


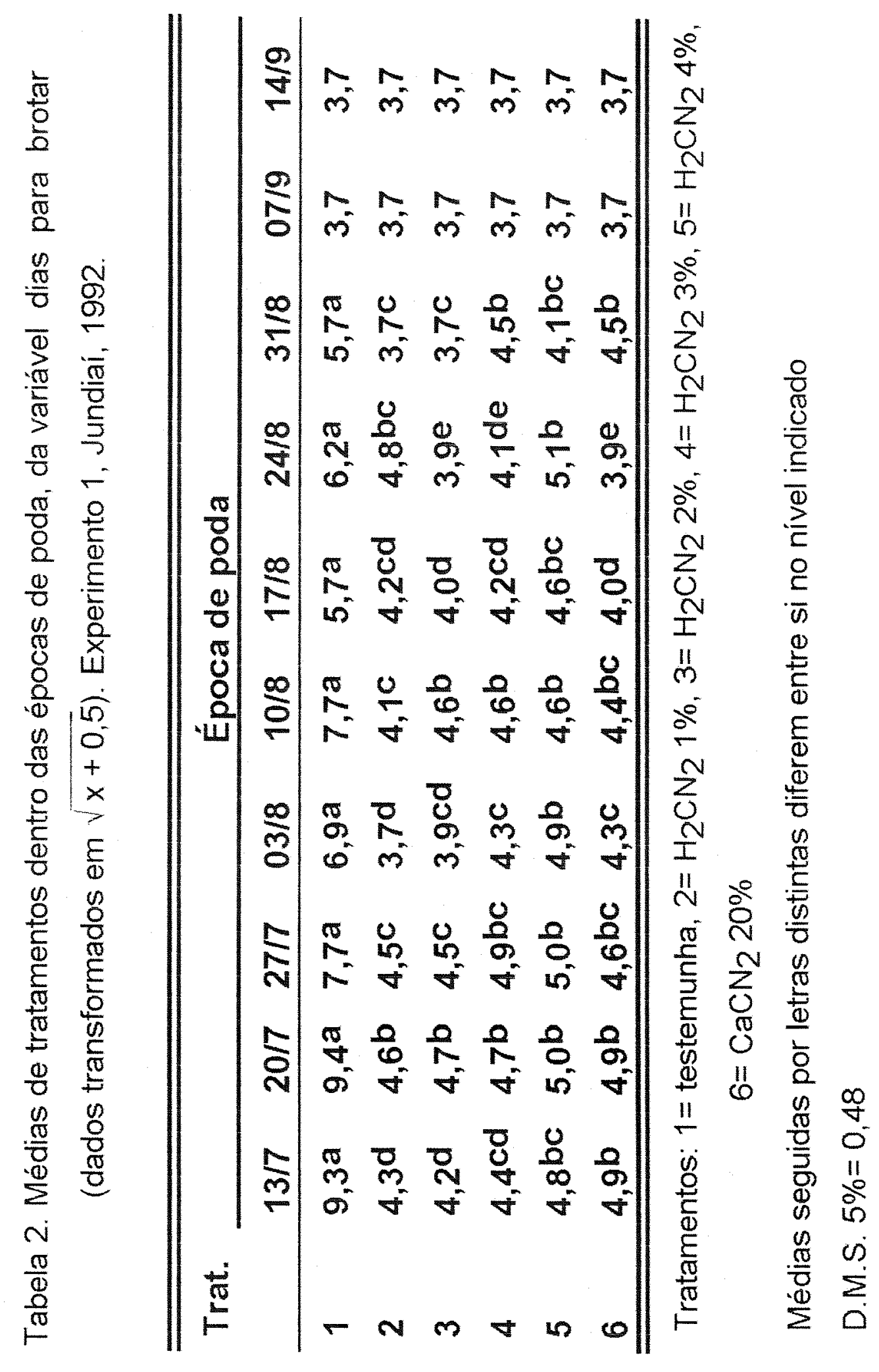


Pela tabela 2 observa-se que nas podas realizadas durante os meses de julho e agosto, todos os tratamentos que receberam os compostos químicos foram estatisticamente superiores aos não tratados; entretanto, nas podas tardias, no mês de setembro, proximo à primavera, todos os tratamentos foram estatisticamente semelhantes. Observa-se também que, nas podas efetuadas nos meses de julho e agosto, a cianamida e a calciocianamida foram semelhantes.

A tabela 3 mostra que houve diferença altamente significativa para o parâmetro porcentagem de brotação de gemas.

Tabela 3. Análise de variancia dos dados de porcentagem de brotaçáa de gemas: Experimento 1. Jundiai, 1992.

$\begin{array}{lllll}\text { Causas da variação } G L & Q M & \text { valor } F & P>F\end{array}$

\begin{tabular}{lrrrr}
\hline Bloco & 4 & & & \\
Época & 9 & 650,1948 & 10,71 & 0,01 \\
Residuo (A) & 36 & 60,6922 & & \\
\hline
\end{tabular}

Parcelas 49

Tratamento

5

6737,1624

83,77

0,01

Épaca X Tratamento

45

382,7625

4.75

0,01

Residuo

(B)

200

16084,2747

80,42

Média Geral: $81,91 \%$

C.V. $(A)=3.88 \%$

C.V. $(B)=10.94 \%$

A tabela 4 apresenta a comparação pelo teste de Tukey dos tratamentos dentro das diferentes épocas de poda. 


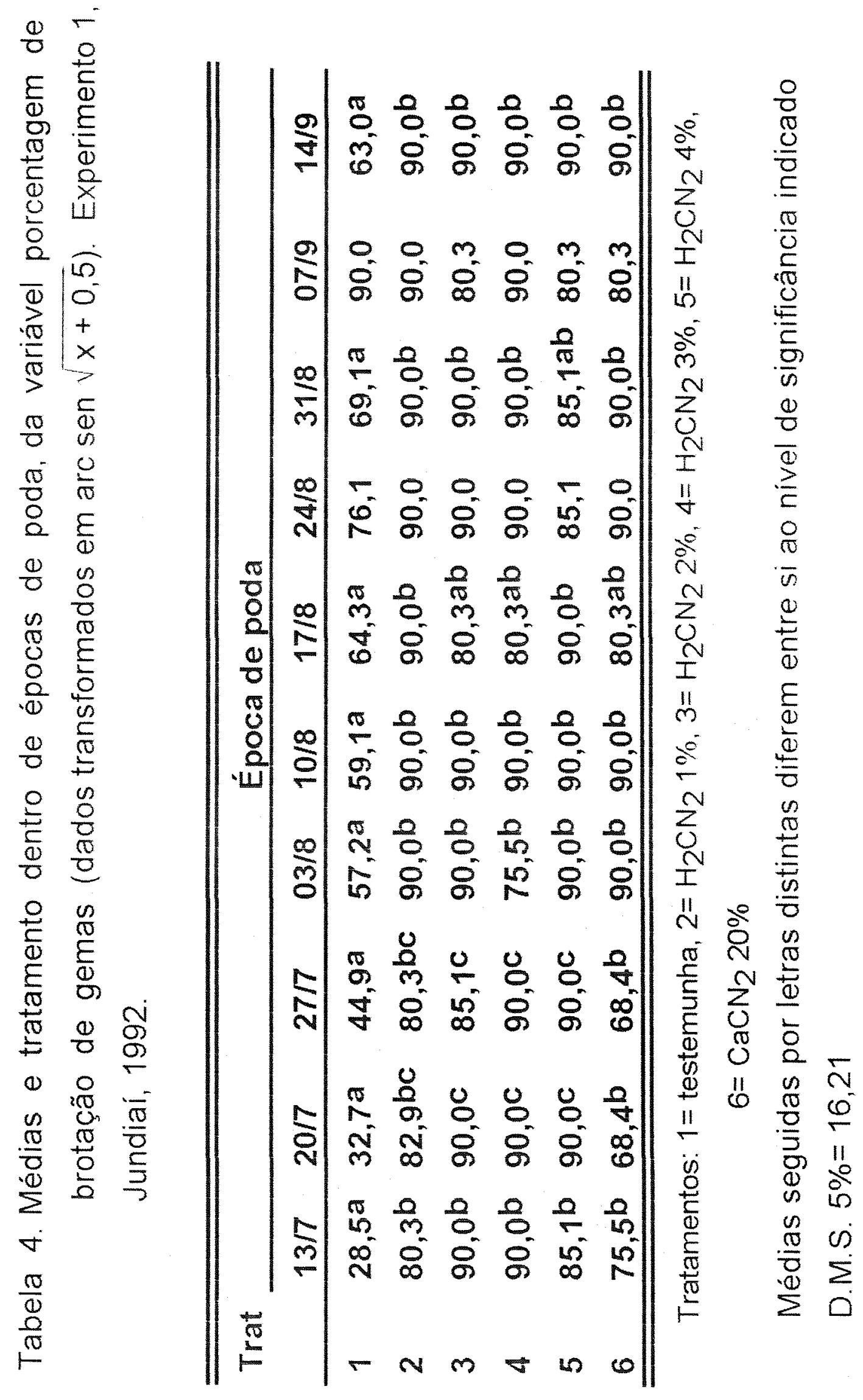


Observa-se que, nas podas realizadas durante o mès de julho até 10 de agosto, todos os tratamentos que receberam os compostos químicos foram estatisticamente superiores aos não tratados; entretanto, nas podas tardias, a partir de 17 de agosto, houve uma tendência de igualdade entre os tratamentos, muito embora os tratamentos que receberam os compostos químicos, praticamente em todas as épocas foram superiores às testemunhas não tratadas. Nota-se também, nas podas efetuadas em todas as épocas, que a cianamida foi semelhante à calciocianamida, no tocante à quantidade de gemas brotadas ao longo do cordão esporonado. Vê-se também que as diferentes doses de cianamida equivaleram-se, não havendo uma que se destacasse em todas as épocas.

A tabela 5 mostra que houve diferença altamente significativa para o parâmetro ciclo, contado em dias.

Tabela 5. Análise de variância dos dados de cielo Experimento 1, Jundiai, 1992.

\begin{tabular}{lrccc}
\hline Causas da variaçăo & GL & QM & Valor $F$ & F>F \\
\hline Blaco & 4 & & & \\
Épaca & 9 & 6.7439 & 1424,05 & 0.01 \\
Residuo (A) & 36 & 0.0047 & & \\
\hline Parcelas & 49 & & & \\
Tratamento & 5 & 5.1514 & 967.84 & 0.01 \\
Epoca X Tratamento & 45 & 0.7231 & 135.87 & 0.01 \\
Residuo (B) & 200 & 0.0053 & &
\end{tabular}

Média gera $I=11,90$

C.V. $(A)=0.23 \%$

C.V. $(B)=0.61 \%$

A tabela 6 apresenta a comparação pelo teste de Tukey dos tratamentos dentro das diferentes épocas de poda, para ciclo. 


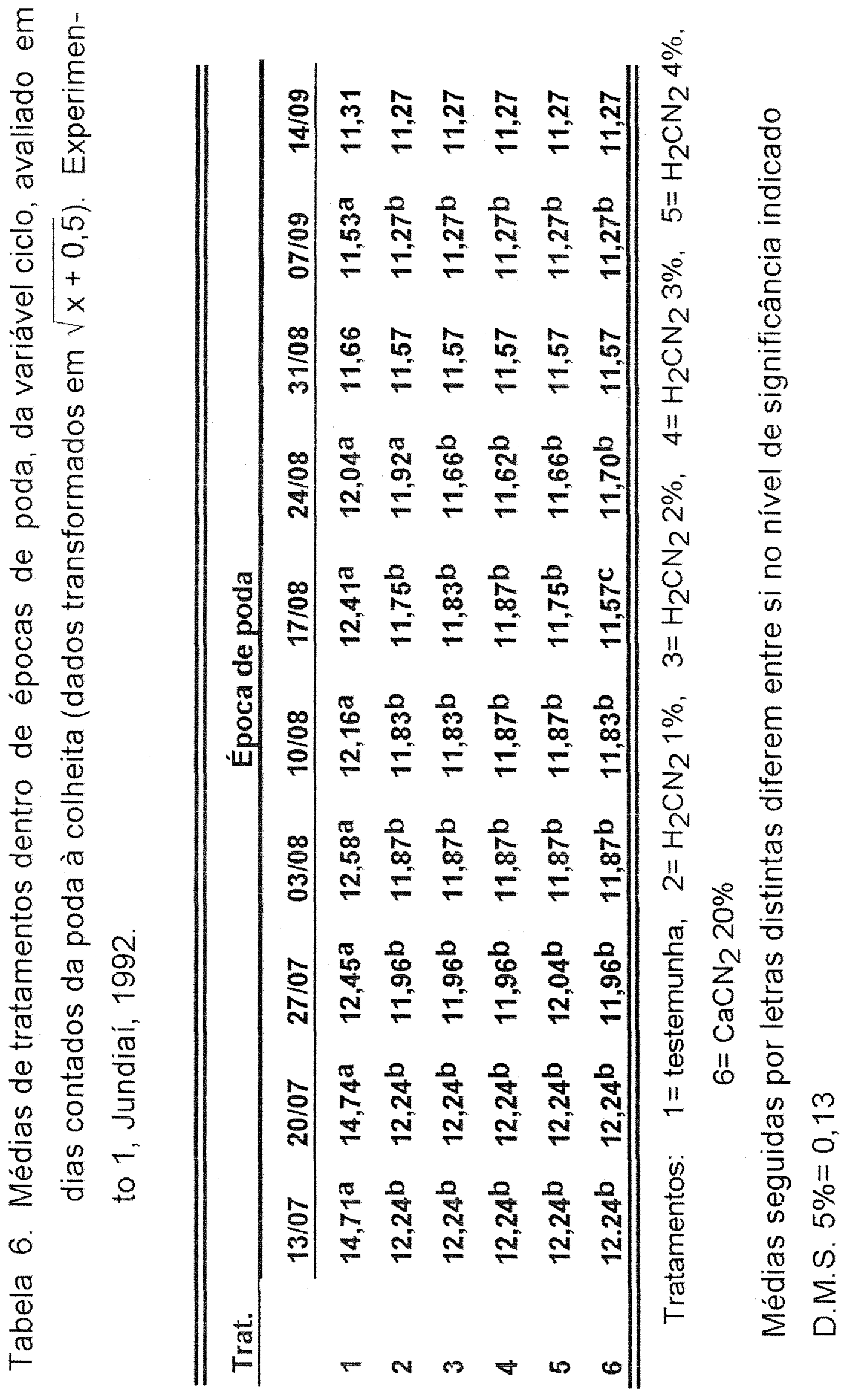


Pela tabela 6 verifica-se que nas podas realizadas no mês de julho e naquelas até 17 de agosto todos os tratamentos que receberam os compostos químicos foram estatisticamente superiores aos não tratados, ou seja, o período poda-colheita foi antecipado. Isto é importante, principalmente nas podas mais precoces, uma vez que a colheita acontecendo, no caso antes das festas de Natal, a remuneração ao produtor é mais compensadora. Verifica-se também, que para este parâmetro, à exceção da testemunha, diferença entre os compostos químicos ocorreu apenas na poda de 17/8, na qual a calciocianamida induziu um ciclo ainda menor daquele proporcionado pela cianamida.

A tabela 7. mostra que houve diferença altamente significativa para o parâmetro número de cachos por planta.

Tabela 7 . Análise de variancia dos dados de número de cachos por planta. Experimento 1.Jundiai. 1992

\begin{tabular}{lrrrr}
\hline Causas da variação & GI & OM & Valor $F$ & P>F \\
\hline Bloco & 4 & & & \\
Epoca & 9 & 1.4189 & 12.08 & 0.01 \\
Residuo (A) & 36 & 0.1173 & & \\
& & & & \\
\hline Parcelas & 49 & & & 0.01 \\
Tratamento & 5 & 12.1721 & 75.18 & 0.01 \\
Epoca X Tratamento & 45 & 1.2655 & 7.81 & \\
Residuo (B) & 200 & 0.1618 & & \\
\end{tabular}

Média geral $=3.66$

C. V. $(A)=3,81 \%$

C. V. $(B)=10,97 \%$

A tabela 8. apresenta a comparação pelo teste de Tukey dos tratamentos dentro das diferentes épocas de poda da variável número de cachos por planta. 


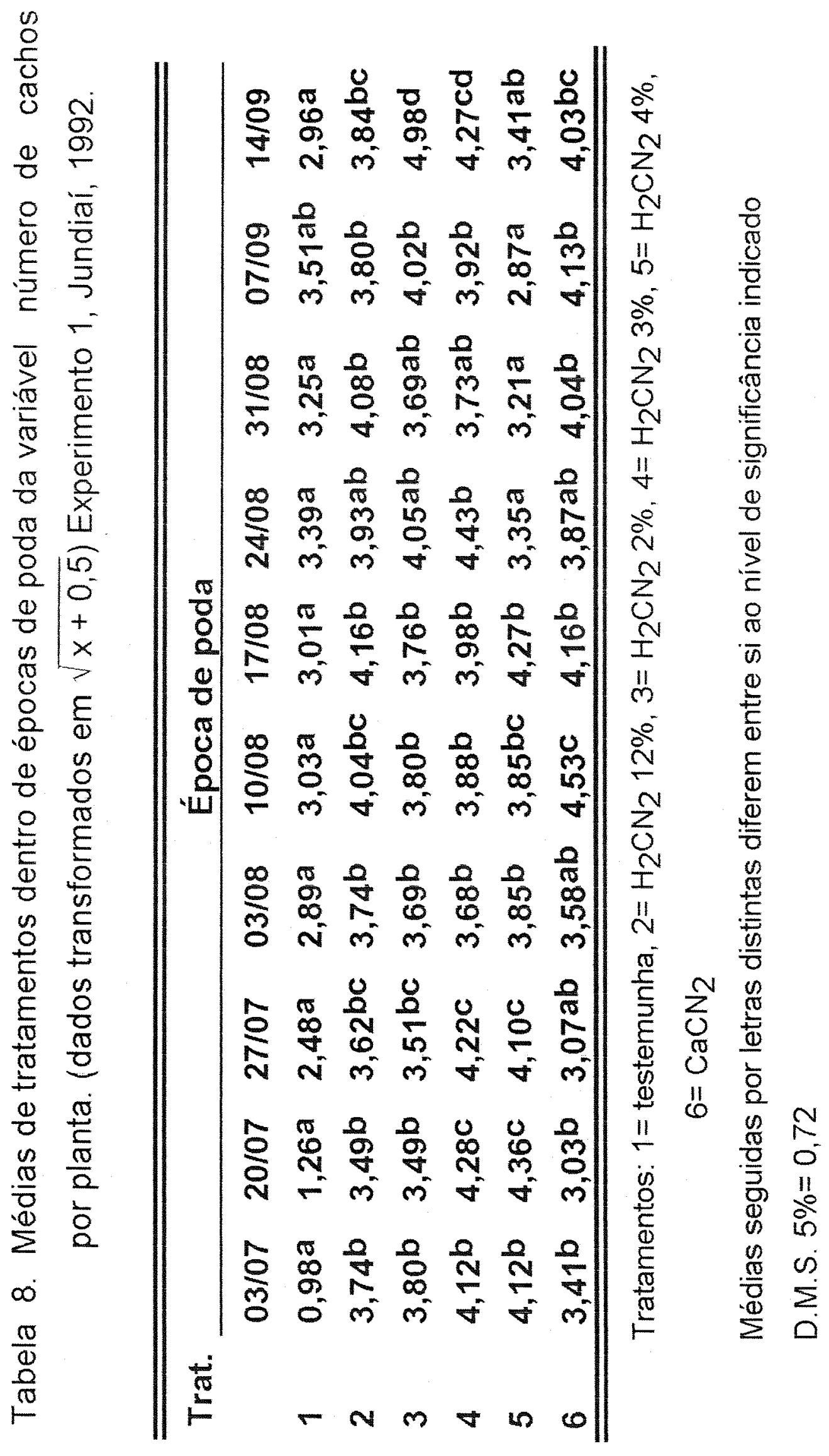


Pelos resultados apresentados na tabela 8 , visualiza-se que, nas podas realizadas até 20 de julho, todos os tratamentos que receberam os compostos químicos foram estatisticamente superiores aos năo tratados.

Os tratamentos com $\mathrm{H}_{2} \mathrm{CN}_{2}$ a $2 \%$ e a $3 \%$ induziram maior número de cachos por planta especialmente na época mais tardia. $\mathrm{Na}$ concentração de $3 \%$ e $4 \%, \mathrm{H}_{2} \mathrm{CN}_{2}$ foi o melhor tratamento nas épocas de 20 e 27/7. Calciocianamida apresentou melhores resultados nas épocas intermediárias. Isso pode indicar que, nas podas feitas mais cedo, há forte necessidade da substituição da falta de frio pela cianamida hidrogenada. Nas podas mais tardias, há uma tendência de equivalência entre os dois produtos

A tabela 9 permite verificar que os tratamentos influenciaram decisivamente o peso médio dos cachos de uva.

Tabela 9. Análise de variancia dos dados de peso médio do cacho. Experimento 1. Jundiai. 1992

\begin{tabular}{lrrrr}
\hline Causas da variação & GL & QM & Valor F & P>F \\
\hline Bloco & 4 & & & \\
Epoca & 9 & 75.2101 & 55.90 & 0.01 \\
Residuo (A) & 36 & 1.3452 & & \\
& & & & \\
\hline Parcelas & 49 & & & \\
Tratamento & 5 & 33.0663 & 25.21 & 0.01 \\
Epoca X Tratamento & 45 & 8.5395 & 6.51 & 0.01 \\
Residuo (B) & 200 & 1.3113 & & - \\
\hline
\end{tabular}

Média Geral $=14,29$

C. V. $(A)=3,31 \%$

C. U. $(B)=8.01 \%$

A tabela 10 apresenta a comparação pelo teste de Tukey dos tratamentos dentro das diferentes épocas de poda. 


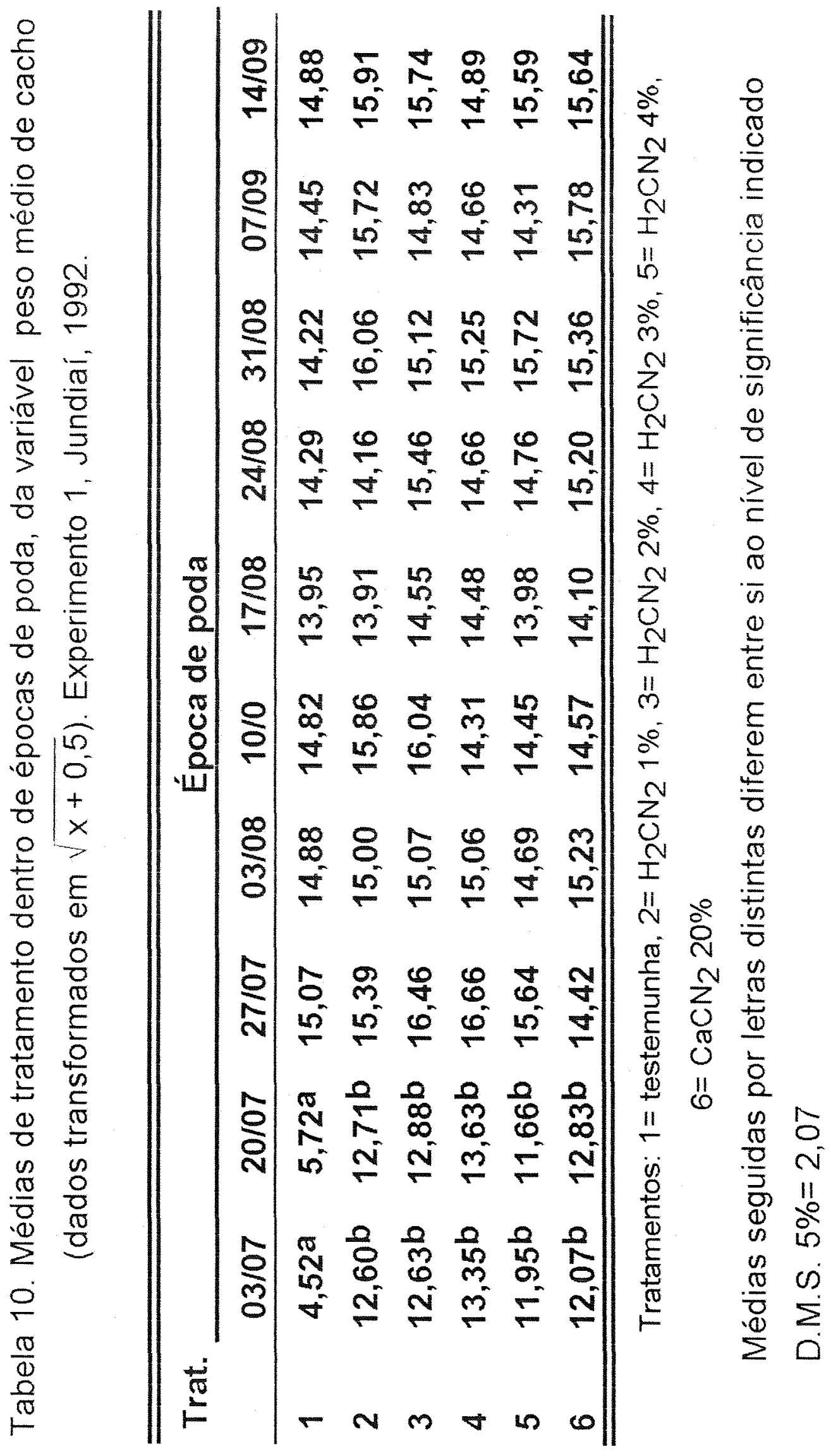


Pela tabela 10, vê-se que o peso do cacho é característica intrínseca da planta, não sendo influenciado por compostos químicos que induzama brotação. Nas duas primeiras épocas, a análise acusou diferença significativa, entretanto acredita-se que seja devido à malformação dos ramos desenvolvidos na testemunha nas podas precoces, originando cachos mal formados e de pesos bem inferiores às demais épocas.

$\mathrm{Na}$ tabela 11 verifica-se que houve, do ponto de vista estatístico, diferença altamente significativa para o parâmetro peso total de cachos por planta.

Tabela 11. Análise de variância dos dados de peso total dos cachos por planta. Experimento 1. Jundiai, 1992

\begin{tabular}{lrcrr}
\hline Causas da variaça & GI & QM & Valor F & P>F \\
\hline Bloco & 4 & & & \\
Epoca & 9 & 0.8873 & 2.24 & 0.01 \\
Residuo (A) & 36 & 0.0275 & & \\
& & & & \\
\hline Parcelas & 49 & & & \\
Tratamento & 5 & 2.1205 & 59.17 & 0.01 \\
Epoca X Tratamento & 45 & 0.1980 & 5.52 & 0.01 \\
Resítuo (B) & 200 & 0.0358 & & \\
\end{tabular}

Média Geral $=1,80$

C. V. $(A)=3,74 \%$

C. V. $(B)=10,47 \%$

A tabela 12 apresenta a comparação pelo teste de Tukey dos tratamentos dentro das diferentes épocas de poda. 


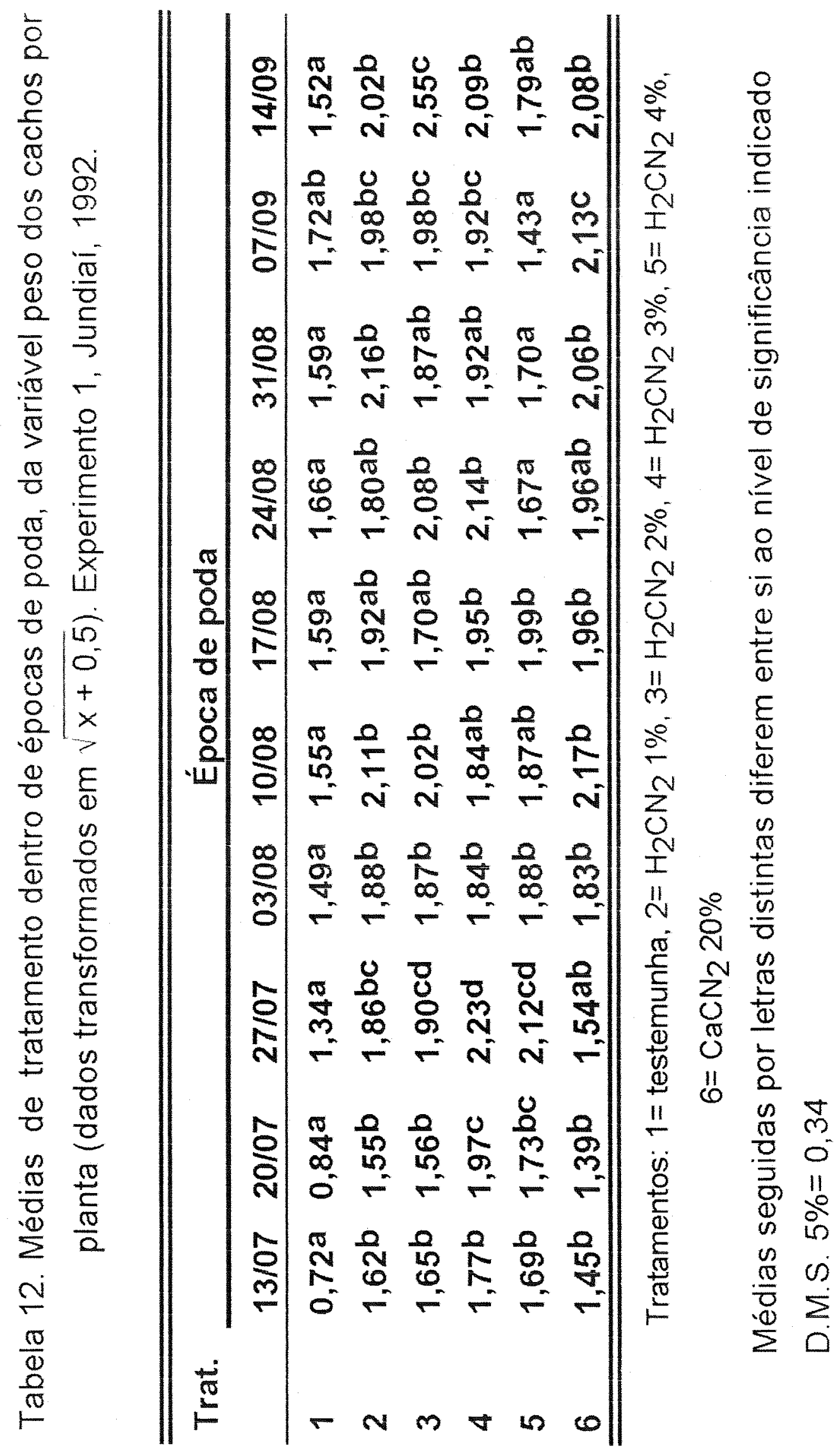


Com poucas exceções, a cianamida hidrogenada e calciocianamida propiciaram melhores produções do que a testemunha, sendo os destaques para $\mathrm{H}_{2} \mathrm{CN}_{2}$ a $3 \%$ nas podas de $20 / 7$ e $27 / 7$ e a $2 \%$ na de $14 / 9$.

Os resultados globais do experimento $1 \mathrm{em}$ Jundiaí concordam com os observados por HATCH \& RUIZ (1987) que, ao estudarem época de poda verificaram que a videira podada no final do inverno apresenta maior porcentagem e uniformidade de brotação.

Da mesma forma aqui encontrada, KUROI et al. (1963); KISHINO et al. (1978); PEREIRA et al. (1979); TERRA et al., (1982 e 1987); PEREIRA \& OLIVEIRA (1978); MIELE et al. (1982); SHULMAN et al. (1982); PIRES et al. (1985) concluíram ser a calciocianamida um eficiente composto químico para quebrar a dormência, induzir e aumentar a porcentagem de brotação de gemas, aumentar a produção e diminuir o ciclo, quando aplicada em pincelamento nas gemas da videira imediatamente após a poda.

Por outro lado, IWASAKI (1990) concluiu que a calciocianamida a $20 \%$ tem efeito positivo quando aplicada em poda precoce e que em poda tardia sua eficiéncia é relativa quanto à antecipação e ao aumento na porcentagem de brotação, o que coincide com os dados aqui mostrados.

Quanto à utilização da cianamida hidrogenada, os resultados săo comparáveis aos auferidos por LIN et al. (1982 e 1985); REDDY \& SHIKHAMANY (1989); SHULMAN et al. (1985); BRACHO et al. (1984); CASTERAN (1987); FOOT (1987); MURISIER (1990) ALBUQUERQUE \& SOBRAL (1989); ZELLEKE \& KLIEWER, (1989); que concluiram que a cianamida aplicada após a poda antecipa, uniformiza e aumenta a porcentagem de brotação de gemas de videira, diminui o ciclo e aumenta a produtividade da planta. Concordam também com JENSEN \& BETIGA (1984) e LUVISI (1984) que verificaram que a cianamida aplicada em podas realizadas ao final do inverno não antecipa a brotaçăo e nem diminui o ciclo da videira.

No que se refere à eficiência dos compostos químicos, os resultados deste trabalho discordam dos de SHULMAN et al. (1983) e AMBERGER (1984), que reportam ser a cianamida mais eficiente que a calciocianamida, em virtude desta sofrer uma hidrólise parcial para o ion cianamida hidrogenada que é a parte ativa do produto. Discordam também dos resultados obtidos por WILLIANS (1987) que năo obteve resultados estatisticamente diferentes para os dados de 
ciclo, peso médio de 100 bagas, cachos por planta e produção por hectare para as videiras tratadas com cianamida em relaçăo à teștemunha.

\subsubsection{Experimento 2}

Este experimento procurou analisar 0 efeito de doses crescentes de cianamida hidrogenada, de 0,0 a 2,0\% em uma época de poda.

A tabela 13 mostra que houve, do ponto de vista estatistico, diferença significativa para os parâmetros dias para brotar, porcentagem de brotação das gemas, ciclo, número de cachos por planta, peso médio de cacho e peso de cachos por planta. 


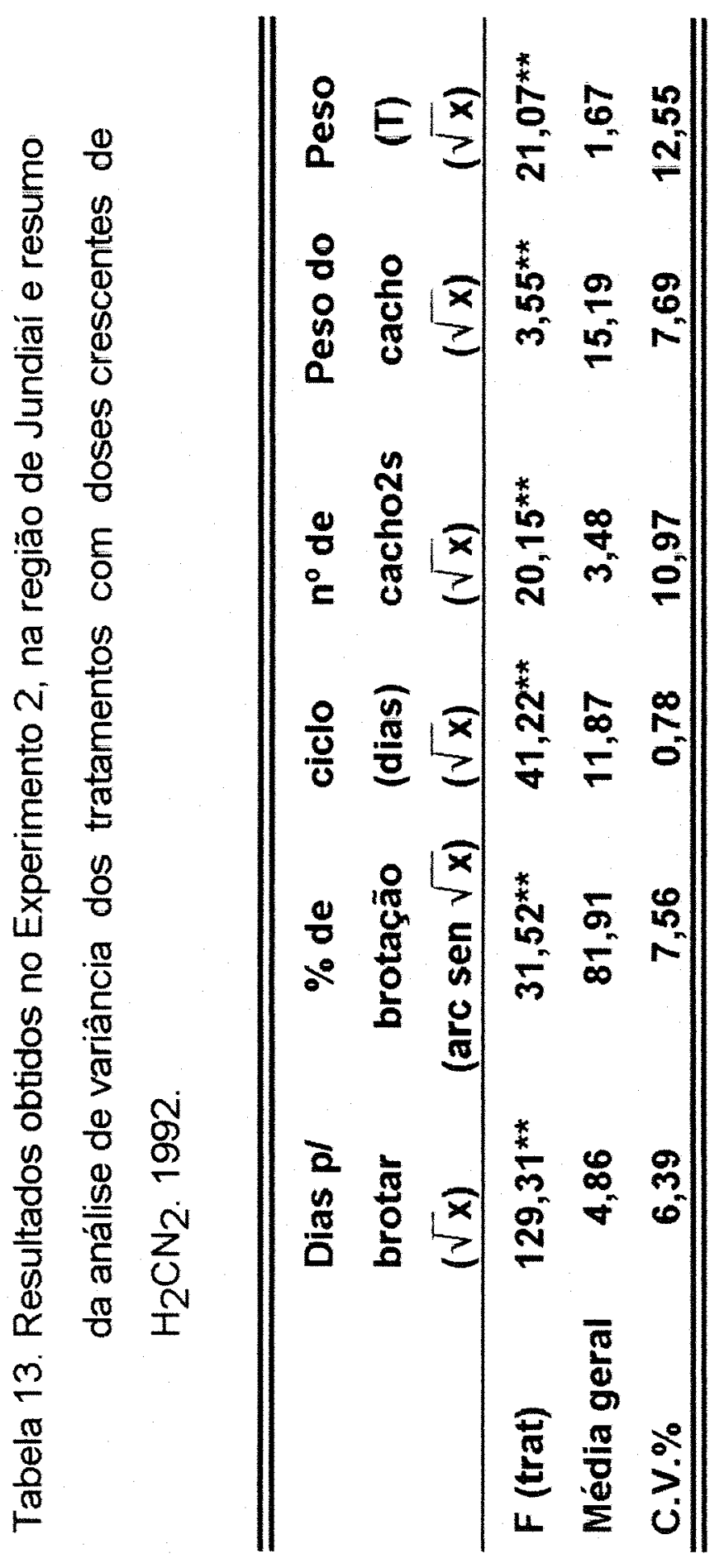


A pulverização de $\mathrm{H}_{2} \mathrm{CN}_{2}$ por ocasião da poda seca, causou um efeito altamente significativo na variável dias para brotar (Figura 1), na porcentagem de gemas brotadas (Figura 2), no ciclo da videira (Figura 3), no número de cachos por planta (Figura 4), no peso total de cachos (Figura 5), com variação da forma quadrática. As curvas ajustadas indicam que as concentrações de $1,46 \% ; 1,44 \% ; 1,63 \% ; 1,63 \%$ e $1,63 \%$ respectivamente foram as melhores para os parâmetros acima mencionados.

A tabela 14, mostra que não houve significância estatistica para a regressão polinomial para o parâmetro peso médio do cacho.

Tabela 14. Anélise de variancia da regressão polinomial para os niveis dos dados de tratamento. Peso médio do cacho. Experimento 2. Jundiai, 1992

Causas da variaça $G I \quad$ OH $\quad$ valor $F \quad P>E$

\begin{tabular}{lrrrr}
\hline Regressão linear & 1 & 1.3349 & 0.97 & 0.66 \\
Regressão quadrática & 1 & 3.1164 & 2.28 & 0.14 \\
Desvios de regressão & 3 & 6.6058 & 4.83 & 0.01 \\
Residuo & 20 & 1.3659 & & \\
\hline
\end{tabular}




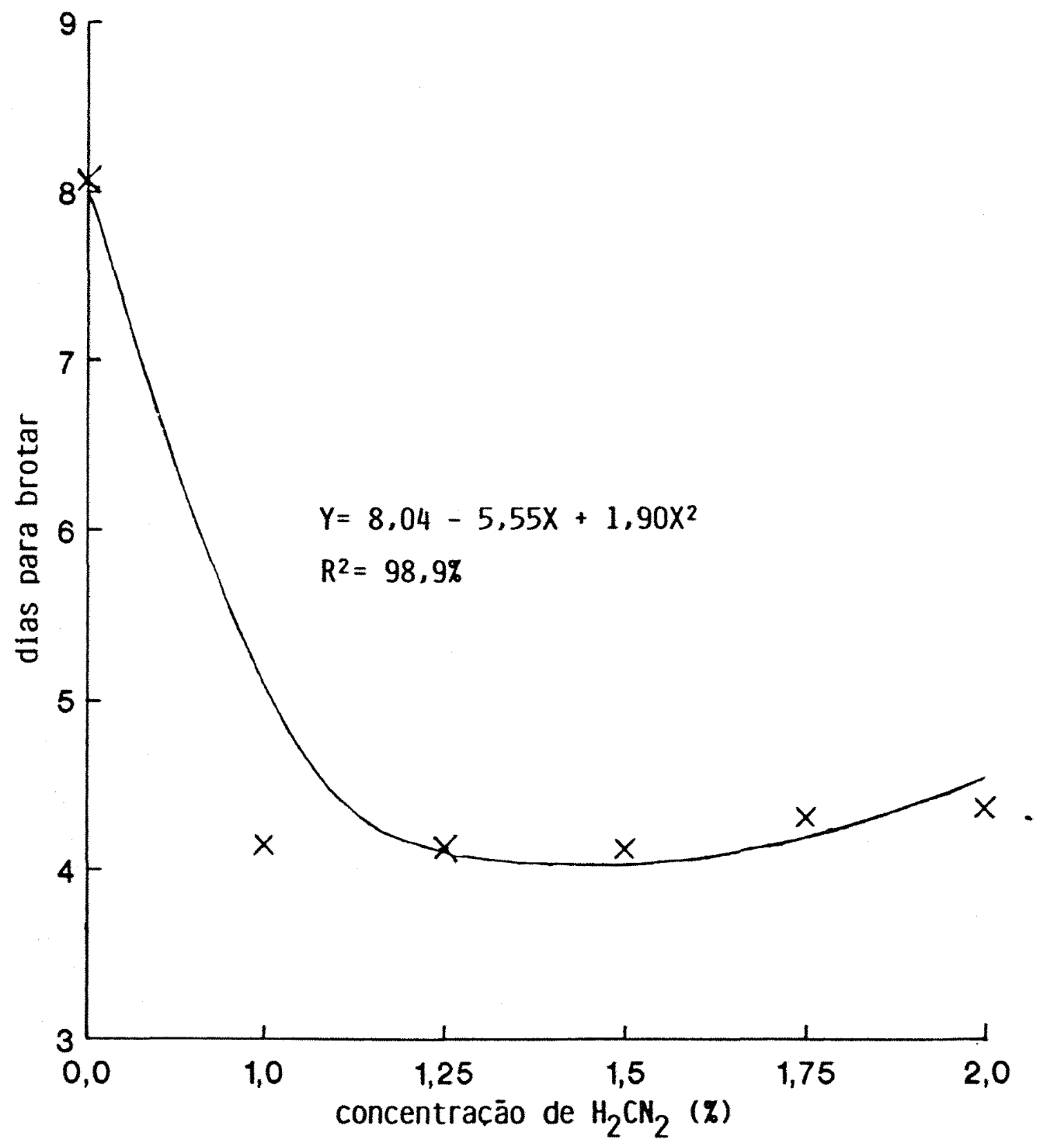

Figura 1. Efeito de concentrações crescentes de $\mathrm{H}_{2} \mathrm{CN}_{2}$ no número de dias para brotar (dados transformados em $\sqrt{x+0,5}$ ) da videira Niagara Rosada. Jundiai. 1992. 


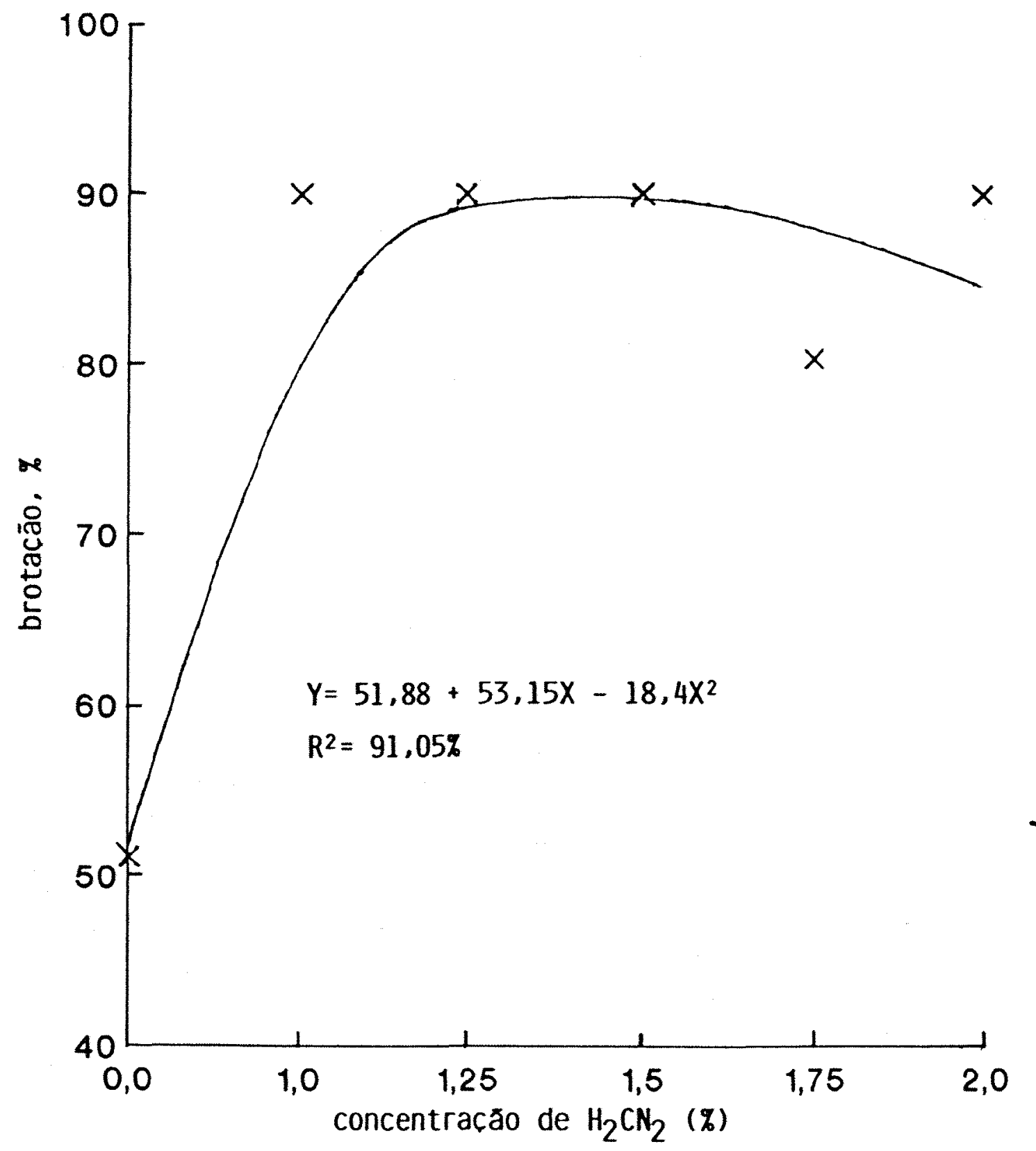

Figura 2. Efeito de concentraçōes crescentes de $\mathrm{H}_{2} \mathrm{CN}_{2}$ na porcentagem de brotação (dados transformados em arc, sen. $\sqrt{x+0,5)}$ da videira Niagara Rosada. Jundiaí. 1992. 


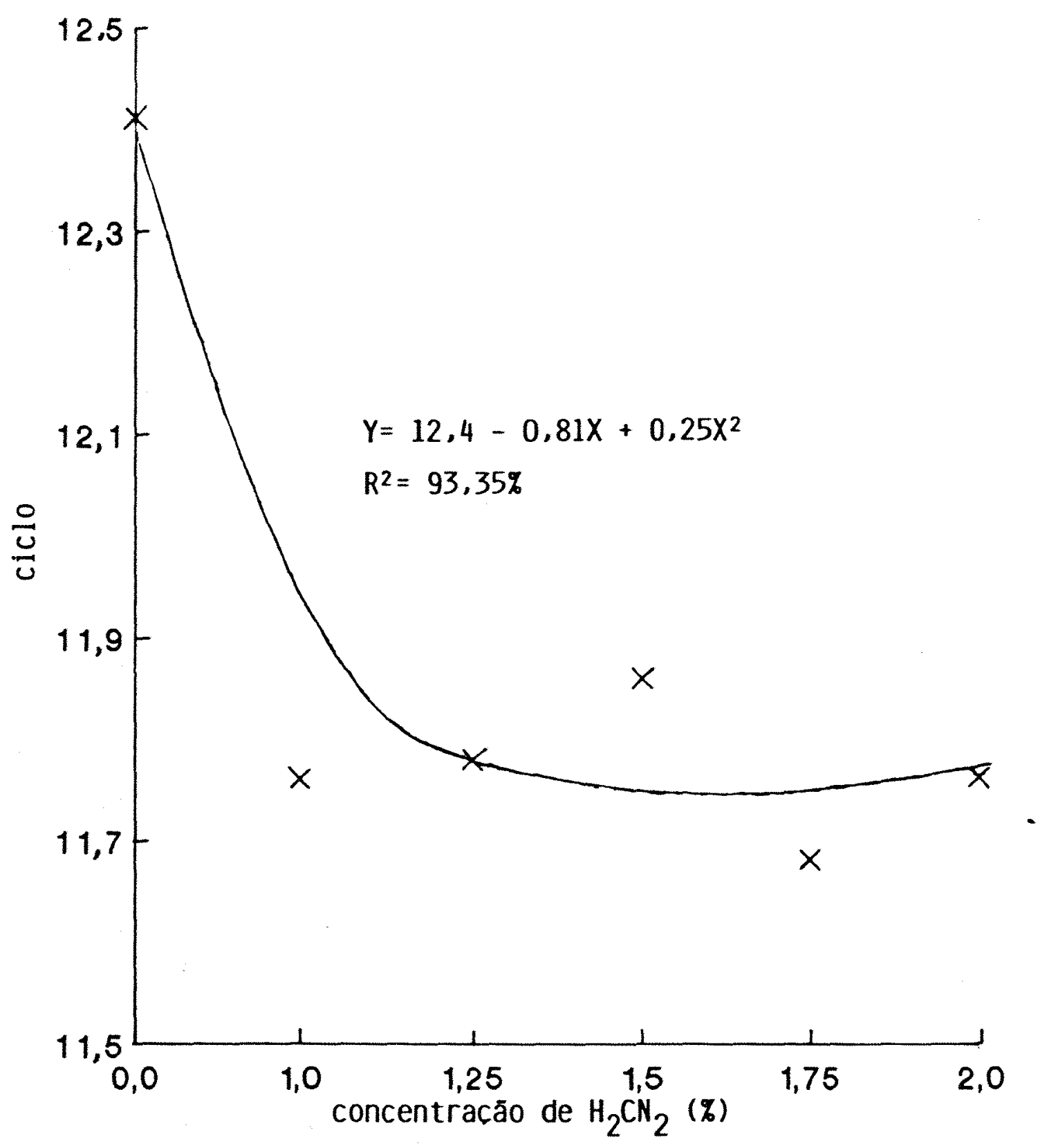

Figura 3. Efeito de concentracōes crescentes de $\mathrm{H}_{2} \mathrm{CN}_{2}$ no ciclo, medido da poda à colheita, (dados transformados em $\sqrt{x+0,5}$ ) da videira Niagara Rosada. Jundiaĩ. 1992. 


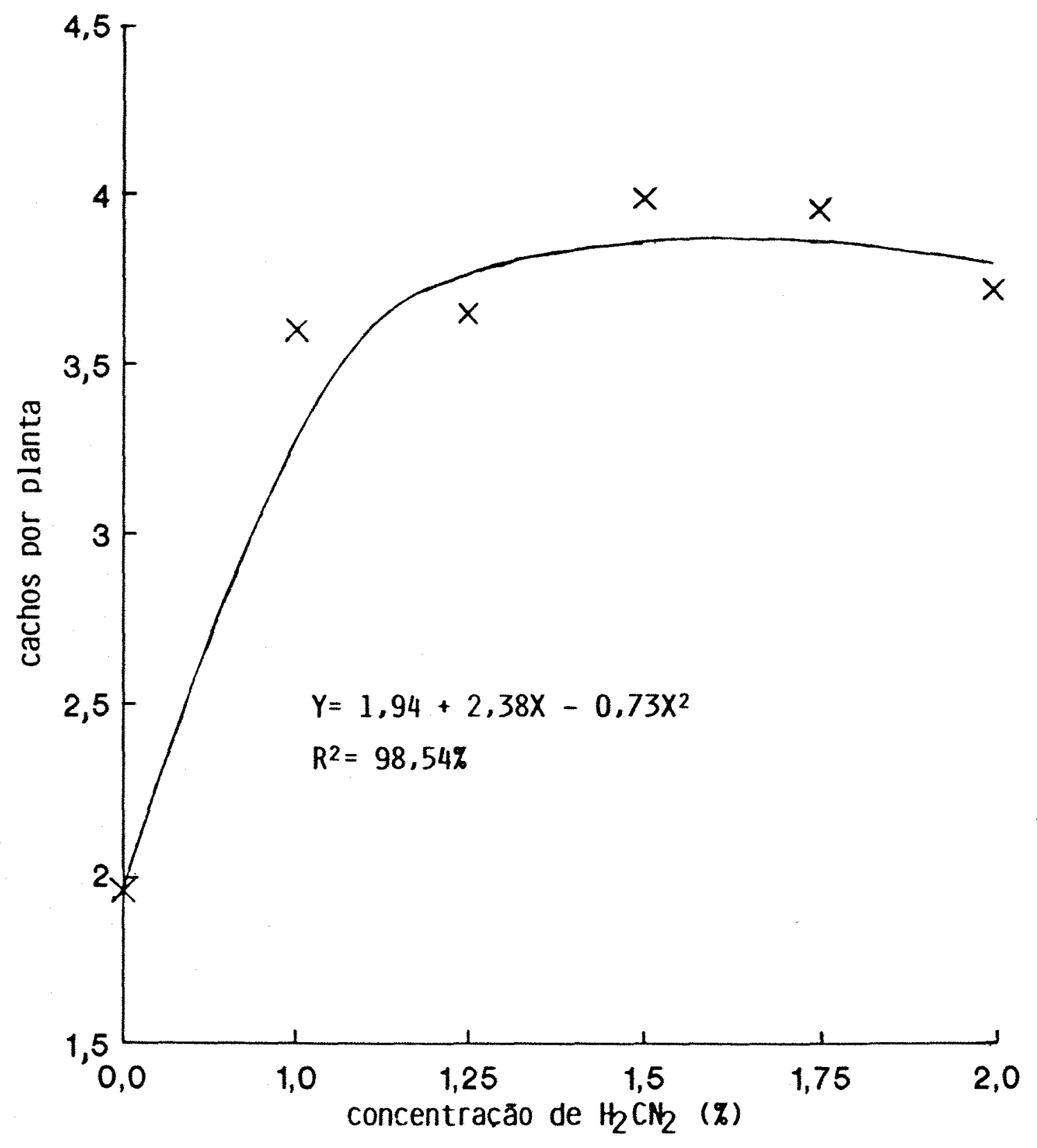

Figura 4. Efeito de concentracōes crescentes de $\mathrm{H}_{2} \mathrm{CN}_{2}$ no número de cachos por planta (dados transformados em $\sqrt{x+0,5}$ da videira Niagara Rosada. Jundiaí. 1992. 


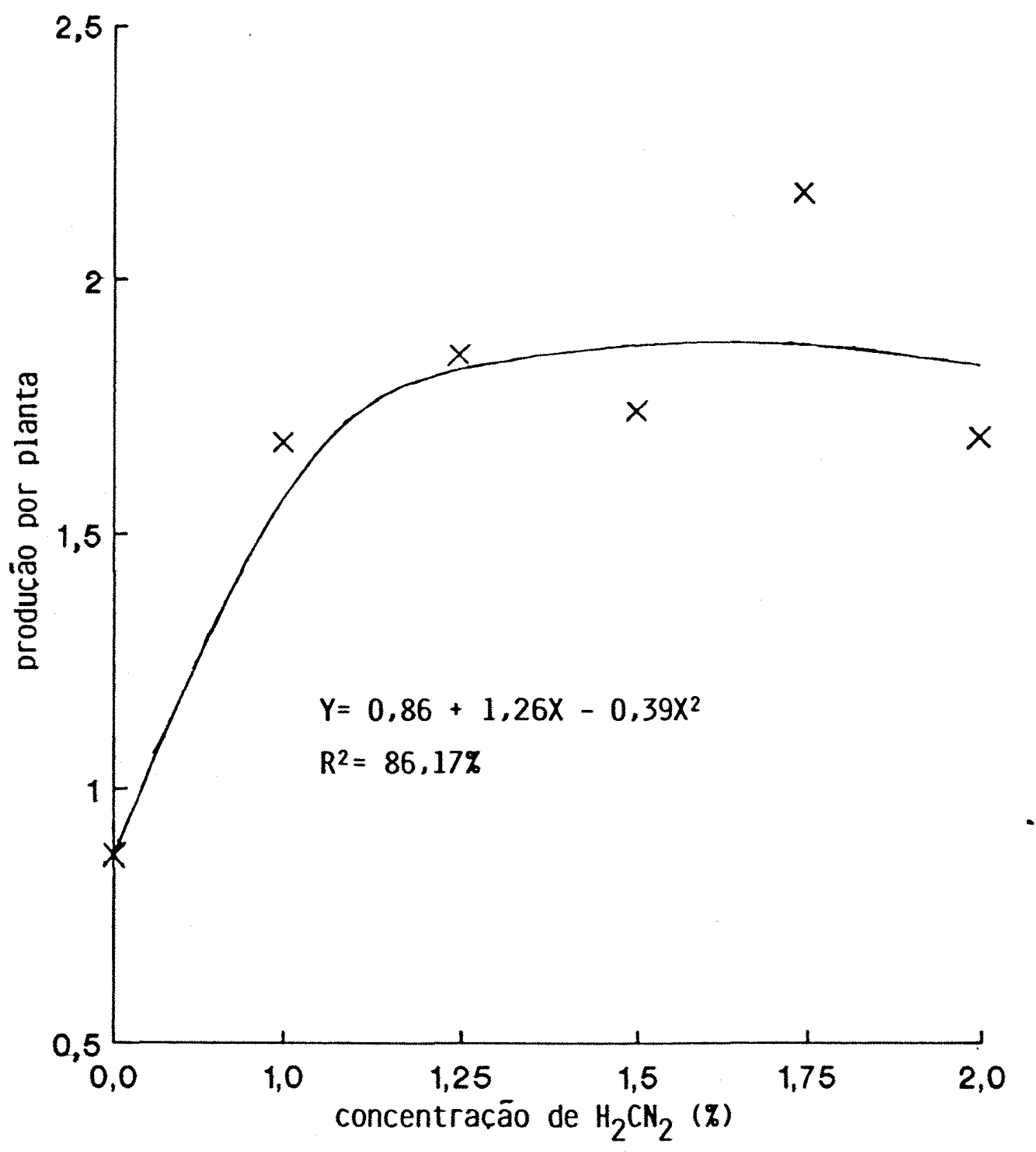

Figura 5. Efeit to de concentraçōes crescentes de $\mathrm{H}_{2} \mathrm{CN}_{2}$ na produçāo por planta (dados transformados em $\sqrt{x}$ ) da videira Niagara Rosada. Ju ndiaí. 1992 
Com relação à eficácia de $\mathrm{H}_{2} \mathrm{CN}_{2}$ para estimular, antecipar e aumentar a porcentagem de brotação, incrementar a produçăo, diminuir o ciclo, os resultados deste trabalho concordam com os de REDDY \& SHIKHAMANY (1989), SHULMAN et al. (1985), BRACHO et al. (1984), WHITING \& COOMBE (1984) WICKS et al. (1984), CASTERAN (1987), FOOT (1987), ZELLEKE \& KLIEWER (1989), MIELE (1991), SILLER-CEPEDA et al. (1994), e discordam dos de JENSEN \& BETIGA (1984) cujas plantas tiveram a brotação atrasada quando receberam $\mathrm{H}_{2} \mathrm{CN}_{2} 2,5 \%$ após a poda.

Entretanto, quanto à concentraçăo empregada, na obtençăo de resultados positivos para os parâmetros analisados neste experimento, há coincidência com os resultados obtidos por BRACHO et al. (1984), WHITING \& COOMBE (1984), WICKS et al. (1984), ZELLEKE \& KLIEWER (1989), e MIELE (1991) que tiveram sucesso quando utilizaram $\mathrm{H}_{2} \mathrm{CN}_{2}$ em concentrações baixas, entre 1 e $2 \%$. Entretanto, são diferentes dos obtidos nos trabalhos de REDDY \& SHIKHAMANY (1989), SHULMAN et al. (1985), BRACHO et al. (1984), CASTERAN (1987) e FOOT (1987), que encontraram resultados positivos com $\mathrm{H}_{2} \mathrm{CN}_{2}$ em doses mais elevadas.

\subsection{Região de Indaiatuba}

\subsubsection{Experimento 1}

Neste experimento foi avaliado o efeito dos tratamentos testemunha, $\mathrm{H}_{2} \mathrm{CN}_{2} 1 \%, \mathrm{H}_{2} \mathrm{CN}_{2} 1,25 \%, \mathrm{H}_{2} \mathrm{CN}_{2} 1,5 \%, \mathrm{H}_{2} \mathrm{CN}_{2} 1,7 \%, \mathrm{H}_{2} \mathrm{CN}_{2}$ $2,0 \%, \mathrm{CaCN}_{2} 20 \%, \mathrm{Ca}\left(\mathrm{NO}_{3}\right)_{2} 5 \%+\mathrm{KNO}_{3} 5 \%, \mathrm{Ca}\left(\mathrm{NO}_{3}\right)_{2} 5 \%+\mathrm{KNO}_{3} 5 \%+$ $\mathrm{H}_{2} \mathrm{CN}_{2} \mathrm{O}, 25 \%, \mathrm{H}_{2} \mathrm{CN}_{2} 0,25 \%, \mathrm{Ca}\left(\mathrm{NO}_{3}\right)_{2} 5 \%+\mathrm{KNO}_{3} 5 \%+\mathrm{CaCN}_{2} 5 \%, \mathrm{CaCN}_{2}$ $5 \%$, na poda realizada em 6/8/93, sobre os parametros dias para brotar, porcentagem de brotação, período da poda à colheita, número de cachos por planta, peso médio de cacho, peso dos cachos por planta.

Os resultados da análise de variância dos dados estudados, à exceção da porcentagem de brotação e do peso médio do cacho, mostraram que os tratamentos induziram diferenças estatísticas nos demais parâmetros (Tabela 15).

A Tabela 15 apresenta a comparação pelo teste de Tukey das médias dos tratamentos no Experimento 1. 
Tabela 15. Resultados obtidos no Experimento 1, na regiåo de Indaiatuba e resumo da análise de variância. 1993.

\begin{tabular}{|c|c|c|c|c|c|c|}
\hline \multirow[t]{2}{*}{ Trat. } & \multicolumn{6}{|c|}{ Parâmetro } \\
\hline & $\begin{array}{l}\text { Dias p/ } \\
\text { brotar } \\
(\sqrt{ } x)\end{array}$ & $\begin{array}{c}\% \text { de } \\
\text { brotação } \\
\text { (arc sen } \sqrt{ } \mathbf{x})\end{array}$ & $\begin{array}{l}\text { Ciclo } \\
(\sqrt{ } x)\end{array}$ & $\begin{array}{l}\text { No de } \\
\text { cachos } \\
(\sqrt{ } x)\end{array}$ & $\begin{array}{c}\text { Peso do } \\
\text { cacho } \\
(\sqrt{ } x)\end{array}$ & $\begin{array}{c}\text { Peso } T \\
(\sqrt{x})\end{array}$ \\
\hline 1 & $6,0^{a}$ & 80,36 & $12,24^{a}$ & $3,129 b c$ & 13,49 & $1,36^{\mathrm{bc}}$ \\
\hline 2 & $4,2^{C}$ & 82,94 & $11,71 b$ & $3,17 \mathrm{bc}$ & 14,09 & $1,40 \mathrm{bc}$ \\
\hline 3 & $4,2^{C}$ & 90,00 & $11,73^{b}$ & $4,13^{a}$ & 14,10 & $1,84^{a}$ \\
\hline 4 & $4,4^{C}$ & 85,18 & $11,78^{b}$ & $3,63 \mathrm{abc}$ & 13,80 & $1,58 a b c$ \\
\hline 5 & $4,3 \mathrm{C}$ & 76,18 & $11,78 b$ & $3,89 a b$ & 13,63 & $1,68 \mathrm{abc}$ \\
\hline 6 & $4,4 \mathrm{C}$ & 78,12 & $11,73^{b}$ & $3,14 b c$ & 14,63 & $1,45 \mathrm{bc}$ \\
\hline 7 & $4,6 \mathrm{bc}$ & 82,94 & $11,76^{b}$ & $3,45 a b c$ & 14,18 & $1,55 \mathrm{abc}$ \\
\hline 8 & $5,4^{a}$ & 85,18 & $12,07^{a}$ & $3,35 \mathrm{abc}$ & 14,09 & 1,49abc \\
\hline 9 & $4.4 \mathrm{C}$ & 85.18 & $1,1.76^{b}$ & $3,19 \mathrm{bc}$ & -13.91 & $1,70 a b$ \\
\hline 10 & $4,5 \mathrm{bc}$ & 80,36 & $11,73^{b}$ & $3,37 \mathrm{abc}$ & 14,31 & $1,52 \mathrm{abc}$ \\
\hline 11 & $5,3 a b$ & 61,43 & $12,09 a$ & $2,84^{C}$ & 14,75 & $1,32^{C}$ \\
\hline 12 & $5,9 a$ & 71,36 & $12,13^{a}$ & $3,20 \mathrm{bc}$ & 13,49 & $1,41 \mathrm{bc}$ \\
\hline F (trat.) & $21,75^{\star *}$ & 1,49 & $17,46^{* *}$ & $4,40^{*}$ & 1,41 & $4,09^{*}$ \\
\hline DMS, $5 \%$ & 0,69 & 30,38 & 0,22 & 0,87 & 1,51 & 0,37 \\
\hline C.V.\% & 6,58 & 17,41 & 0,87 & 11,61 & 4,91 & 11,09 \\
\hline
\end{tabular}

Médias seguidas por letras distintas diferem entre si no nível de significância indicado.

Tratamentos: $1=$ testemunha, $2=\mathrm{H}_{2} \mathrm{CN}_{2} 1 \%, 3=\mathrm{H}_{2} \mathrm{CN}_{2} 1,25 \%, 4=\mathrm{H}_{2} \mathrm{CN}_{2}$ $1,5 \%, 5=\mathrm{H}_{2} \mathrm{CN}_{2} 1,7 \%, 6=\mathrm{H}_{2} \mathrm{CN}_{2} 2,0 \%, 7=\mathrm{CaCN}_{2} 20 \%, 8=\mathrm{Ca}\left(\mathrm{NO}_{3}\right)_{2} 5 \%$ $+\mathrm{KNO}_{3} 5 \%, 9=\mathrm{Ca}\left(\mathrm{NO}_{3}\right)_{2} 5 \%+\mathrm{KNO}_{3} 5 \%+\mathrm{H}_{2} \mathrm{CN}_{2} \mathrm{O}, 25 \%, 10=\mathrm{H}_{2} \mathrm{CN}_{2}$ $0,25 \%, 11=\mathrm{Ca}\left(\mathrm{NO}_{3}\right)_{2} 5 \%+\mathrm{KNO}_{3} 5 \%+\mathrm{CaCN}_{2} 5 \%, 12=\mathrm{CaCN}_{2} 5 \%$. 
Pela tabela 15 pode ser observado que todos os tratamentos que receberam cianamida hidrogenada, independentemente da concentraçăo, tiveram sua brotação antecipada em relação à testemunha, mas não diferiram do tratamento que recebeu calciocianamida a $20 \%$, dose usualmente recomendada. Embora pequena, a diferença ocorrida entre a cianamida e a calciocianamida pode ser devida à maior reatividade do primeiro em relação ao segundo. Os demais compostos e a calciocianamida em concentração baixa (5\%), năo apresentaram o efeito positivo desejado e comportaram-se estatisticamente semelhantes à testemunha.

Pela mesma tabela verifica-se que todos os tratamentos comportaram-se de modo estatisticamente semelhante para 0 parâmetro porcentagem de brotação. Entretanto, em condiçðes de campo, o tratamento 3 $\left(\mathrm{H}_{2} \mathrm{CN}_{2} 1,25 \%\right)$ induziu a brotação de $100 \%$ das gemas, enquanto que nos demais tratamentos não houve brotação total das gemas ao longo do cordão esporonado. Isto pode ser comprovado pelos dados que tratam do rendimento da planta, quais sejam número de cachos por planta e peso total por planta, onde o melhor tratamento também foi a pulverização de $\mathrm{H}_{2} \mathrm{CN}_{2} 1,25 \%$.

A tabela 15 mostra que ao antecipar a brotação, os tratamentos que continham cianamida hidrogenada, independentemente da concentração, destacando-se novamente o tratamento 3 e o que continha calciocianamida na concentração usualmente utilizada, anteciparam a colheita, apresentando um ciclo médio de 138 dias, significando que a colheita ocorreu antes do Natal, ou seja, proporcionando uma melhor remuneração ao produtor. Isto para a região de Indaiatuba é muito importante, uma vez que podas mais precoces estão sujeitas às intempéries climáticas como ventos frios e geadas, dentre outros.

O paråmetro peso médio de cacho não foi afetado pelos compostos químicos, mostrando mais uma vez que essa característica é controlada geneticamente, sofrendo pouca ou nenhuma influência.

Os resultados deste experimento demonstram claramente que para a videira, ao contrário de outras frutas decíduas de clima temperado, os compostos químicos efetivos para promover a quebra de dormência, induzindo, uniformizando e aumentando a porcentagem de brotação, e conseqüentemente diminuindo o ciclo e aumentando a produção da videira são, sem dúvida, os que contém o radical $\mathrm{CN}_{2}$, quais sejam a calciocianamida e a cianamida. Também não obtiveram sucesso EMMERSON \& POWELL (1978), AHMEDULLAH et al. (1986), 
e LIN et al. (1983) que fizeram uso de vários compostos quimicos não obtendo também resultados satisfatórios; ALBUQUERQUE \& ALBUQUERQUE (1984) e SHIKHAMANY (1989) que também pesquisaram vários compostos inclusive 0 $\mathrm{KNO}_{3}$, e também năo obtiveram resultados experimentais satisfatórios. Coincidem também com os de KUROI (1985), que obteve éxito empregando a cianamida hidrogenada a partir de doses muito baixas, isto é, $0,5 \%$.

Resultados semelhantes com o uso de $\mathrm{CaCN}_{2}$ e $\mathrm{H}_{2} \mathrm{CN}_{2}$ nas concentrações utilizadas neste trabalho também foram descritos por KISHINO et al. (1978), PEREIRA et al., (1979), TERRA et al. (1982, e 1987), SHULMAN et al. (1983), WHITING \& COOMBE (1984), dentre outros.

\subsubsection{Experimento 2 [Análise de Variância 1 (A.1)]}

Neste experimento foi comparado o efeito dos tratamentos testemunha, $\mathrm{H}_{2} \mathrm{CN}_{2} 1 \%, \mathrm{H}_{2} \mathrm{CN}_{2} 1,25 \%, \mathrm{H}_{2} \mathrm{CN}_{2} 1,5 \%, \mathrm{H}_{2} \mathrm{CN}_{2} 1,75 \%, \mathrm{H}_{2} \mathrm{CN}_{2}$ $2,0 \%, \mathrm{CaCN}_{2} 20 \%$, na poda realizada em $6 / 8 / 93$, sobre parâmetros dias para brotar, porcentagem de brotaçăo, periodo da poda à colheita (ciclo), número de cachos, peso médio de cacho, peso dos cachos por planta.

Os resultados da análise de variância dos dados estudados, à exceção do número de dias para brotar e o ciclo, mostraram que os demais tratamentos não induziram diferenças estatísticas nas demais características (Tabela 16). 


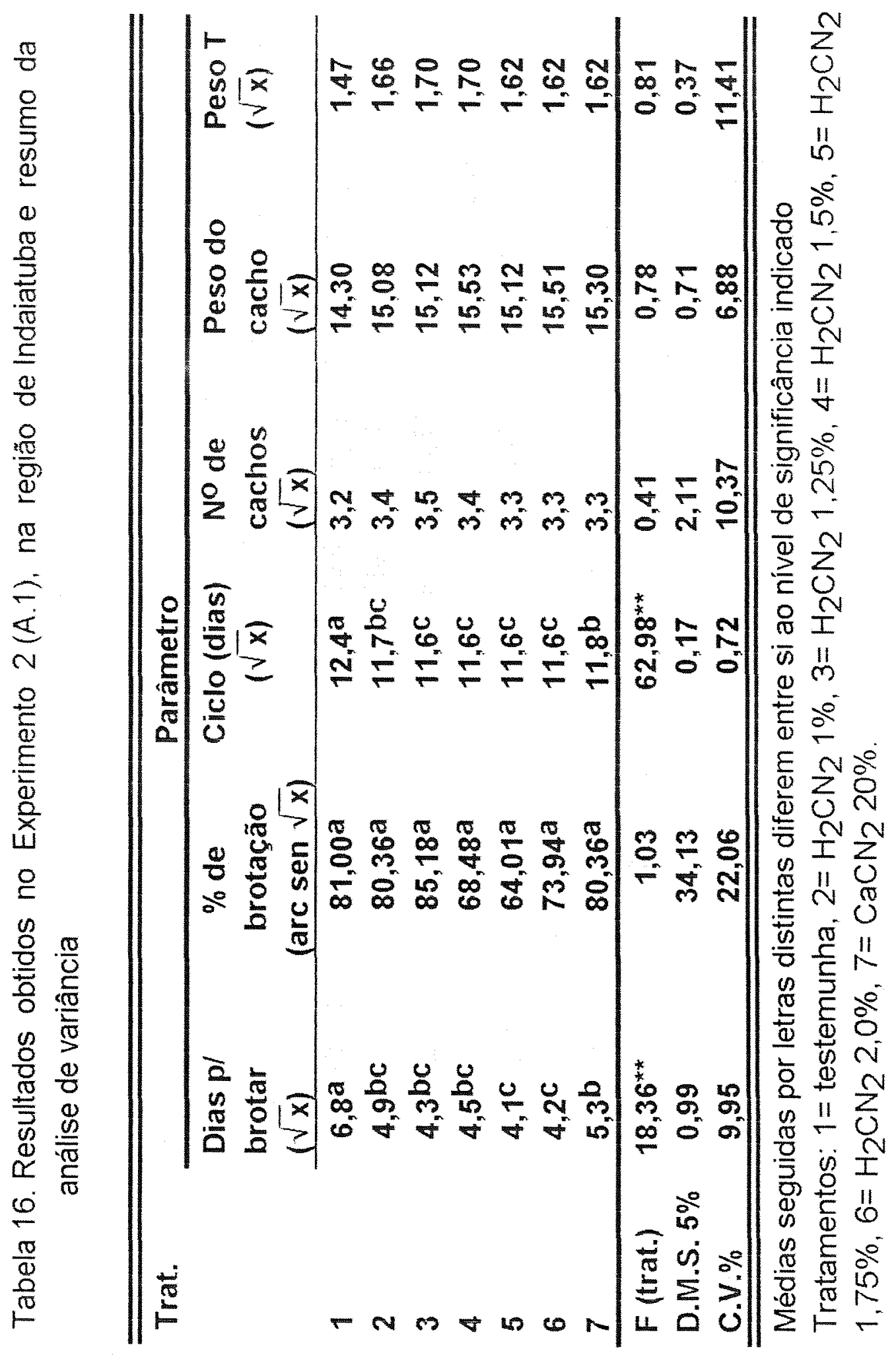


Pelos dados da tabela 16 verifica-se que todos os tratamentos que receberam a aplicaçăo de compostos químicos indutores de quebra de dormência foram superiores ao controle não tratado em relação ao paråmetro dias para brotar e o periodo poda-colheita (ciclo); $\mathrm{H}_{2} \mathrm{CN}_{2}$ a $1,75 \%$ e a $2 \%$ propiciou brotação em tempo menor do que o que foi obtido com a calciocianamida. $\mathrm{H}_{2} \mathrm{CN}_{2}$ nas doses de $1,25 \%, 1,5 \%, 1,75 \%$ e $2,0 \%$ induziu ciclo mais curto do que aquele obtido com a calciocianamida.

Pela mesma tabela, verifica-se que os demais parâmetros não foram afetados pelos tratamentos, isto é, comportaram-se de modo semelhante do ponto de vista estatístico. Entretanto, no campo, o tratamento 3, que recebeu $\mathrm{H}_{2} \mathrm{CN}_{2} 1,25 \%$, apresentou $4,18 \%$ a mais de gemas brotadas e $32,21 \%$ a mais na produção em relação à testemunha.

A semelhança em eficiência ocorrida entre $\mathrm{H}_{2} \mathrm{CN}_{2}$ e $\mathrm{CaCN}_{2}$ já foi discutida nos experimentos anteriores. Entretanto, como as doses crescentes de cianamida comportaram-se de modo diferente do ponto de vista estatístico, foi feito um estudo somente com elas.

\subsubsection{Experimento 2 [Análise de Vaiância 2 (A.2)]}

Este experimento comparou o efeito de doses crescentes de cianamida hidrogenada nas concentraçðes de 0,$0 ; 1,0 ; 1,25 ; 1,75$ e 2,0\% na poda realizada $6 / 8 / 93$.

A tabela 17 indica que houve diferença estatística altamente significativa para o parâmetro dias para brotar.

A pulverização de $\mathrm{H}_{2} \mathrm{CN}_{2}$ por ocasião da poda, causou um efeito altamente significativo na variável dias para brotar, com variação da forma quadrática (Fig. 6). A curva ajustada indica que o menor periodo de tempo para a brotação foi obtido na concentração de 1,93\%.

A tabela 17 apresenta ainda os dados da análise de variância do efeito das concentrações de $\mathrm{H}_{2} \mathrm{CN}_{2}$ sobre a porcentagem de brotação de gemas. Verifica-se que as diferentes doses do produto não influenciaram estatisticamente o parâmetro analisado.

Pela tabela 17, verifica-se também que houve diferença estatística altamente significativa entre os tratamentos para o parâmetro ciclo.

O ciclo da videira, periodo que vai da brotação à colheita, respondeu de forma quadrática à aplicação dos compostos químicos (Figura 7), de 
forma que quanto mais rapidamente as gemas brotaram, menor foi o período de tempo para colher seus frutos. A curva ajustada indica que o menor número de dias entre a poda e a colheita foi obtido com a dose de $1,66 \%$. 


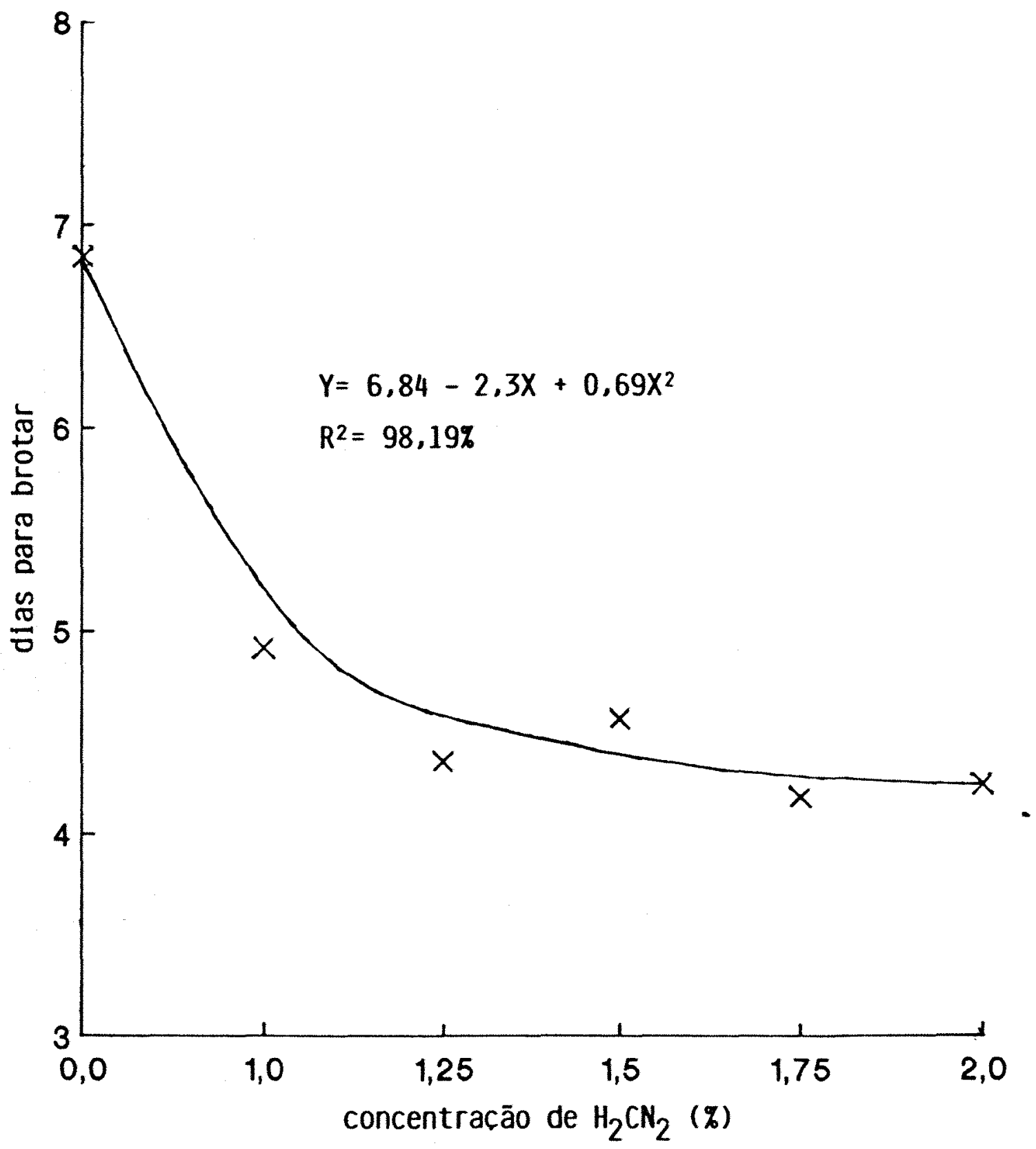

Figura 6. Efeito de concentracōes crescentes de $\mathrm{H}_{2} \mathrm{CN}_{2}$ no número de dias para brotar (dados transformados em $\sqrt{x}$ ) da videira Niagara Rosada. Indaiatuba. 1993. 


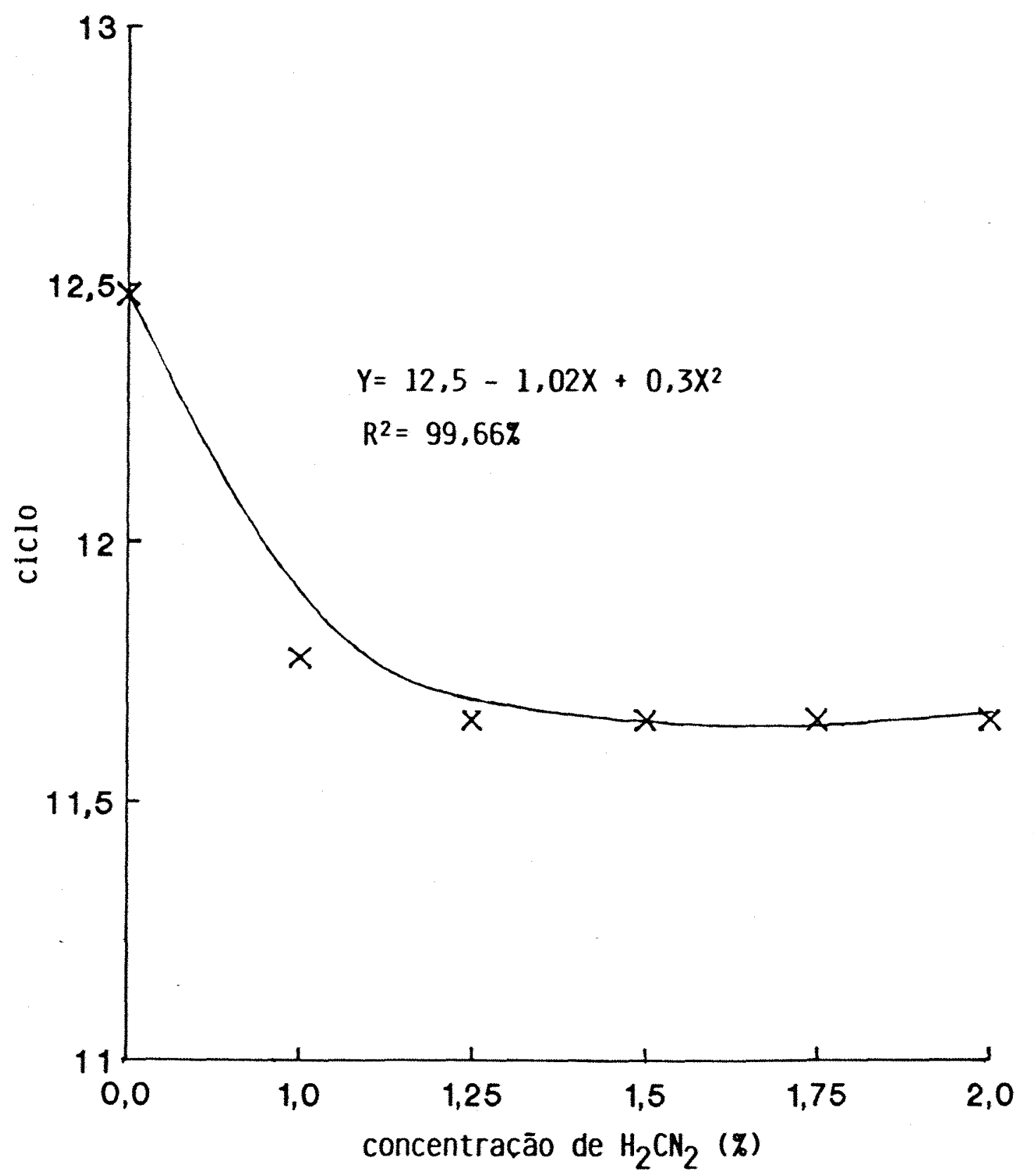

Figura 7. Efeito de concentraçōes crescentes de $\mathrm{H}_{2} \mathrm{CN}_{2}$ no ciclo, medido em dias da poda à colheita, (dados transformados em $\sqrt{x}$ ) da videira Niagara Rosada. Indaiatuba. 1993. 


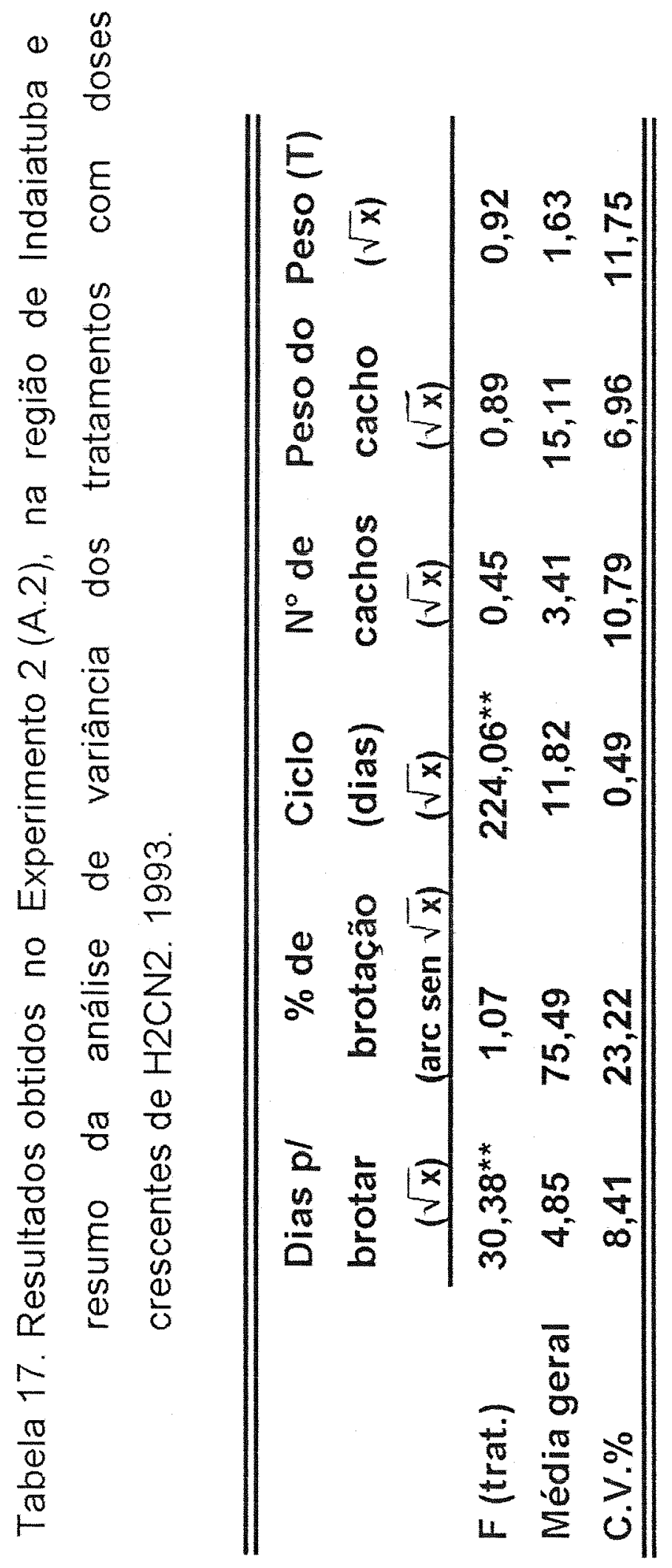


Não houve efeito estatisticamente significativo para os parâmetros número de cachos por planta, peso médio do cacho e peso total por planta respectivamente (Tabela 17). Entretanto, no campo, as plantas que receberam $\mathrm{H}_{2} \mathrm{CN}_{2} 1,25 \%$ e $1,5 \%$ tiveram um rendimento $32,22 \%$ a mais do que as plantas que receberam $\mathrm{H}_{2} \mathrm{CN}_{2}$ em concentrações mais elevadas.

Estes resultados são comparáveis aos obtidos por ZELLEKE \& KLIEWER (1989) que detectaram que a cianamida em concentrações baixas, de 1 a $2 \%$, é mais eficiente em videiras jovens.

\subsection{REGIÃO DE SÃO MIGUEL ARCANJO}

\subsubsection{Experimento 1 [Análise de Variância 1 (A.1)]}

Este experimento procurou esclarecer 0 efeito dos tratamentos $\mathrm{H}_{2} \mathrm{CN}_{2} 1 \%, \mathrm{H}_{2} \mathrm{CN}_{2} 2 \%, \mathrm{H}_{2} \mathrm{CN}_{2} 3 \%, \mathrm{H}_{2} \mathrm{CN}_{2} 4 \%, \mathrm{H}_{2} \mathrm{CN}_{2} 5 \%, \mathrm{H}_{2} \mathrm{CN}_{2} 6 \%$ e $\mathrm{CaCN}_{2} 20 \%$, na poda realizada em $16 / 8 / 1991$, sobre os paråmetros porcentagem de brotação da gema principal, porcentagem de brotação de gemas velhas, porcentagem de brotação total, número de cachos, peso médio do cacho, peso dos cachos por planta. 


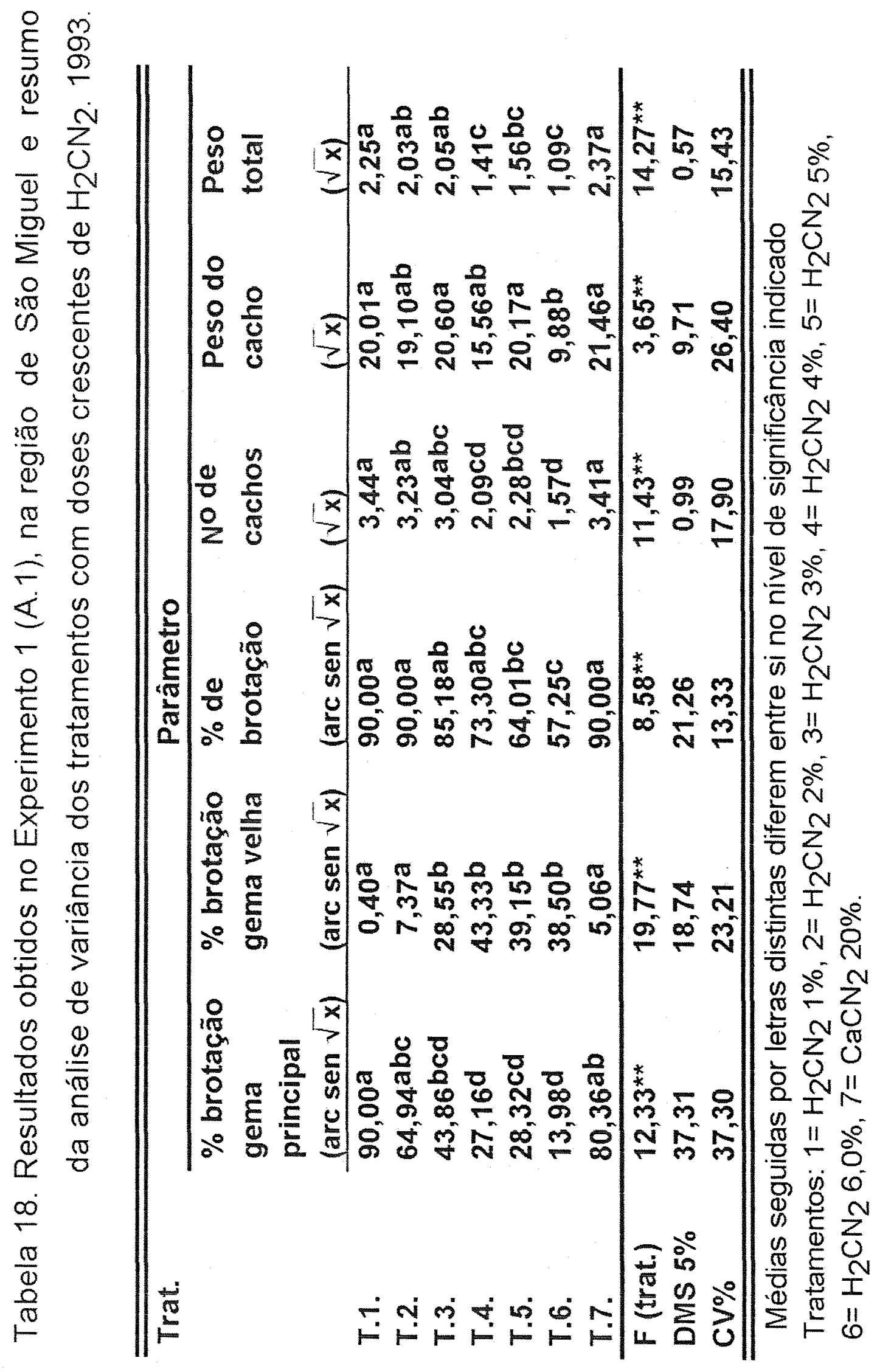


Os resultados mostrados na tabela 18 indicam que os tratamentos aplicados induziram diferenças significativas em todas as caracteristicas estudadas. $\mathrm{H}_{2} \mathrm{CN}_{2}$ nas doses de $3,4,5$ e $6 \%$ não foi eficiente para induzir a brotaçăo da gema principal tanto quanto a calciocianamida $20 \%$ e $\mathrm{H}_{2} \mathrm{CN}_{2}$ a 1 e $2 \%$. Por outro lado, $\mathrm{H}_{2} \mathrm{CN}_{2}$ nas doses de $3,4,5$ e $6 \%$ propiciou as melhores porcentagens de brotação das gemas velhas, superando $\mathrm{CaCN}_{2} 20 \%$ e a $\mathrm{H}_{2} \mathrm{CN}_{2} 1$ e $2 \%$. Já no tocante à brotação total, $\mathrm{H}_{2} \mathrm{CN}_{2}$ a 5 e $6 \%$ proporcionou as menores porcentagens, superadas estatisticamente por $\mathrm{H}_{2} \mathrm{CN}_{2}$ a 1 e $2 \%$ e pela $\mathrm{CaCN}_{2}$ a $20 \%$.

O maior número de cachos foi observado nas plantas que receberam $\mathrm{H}_{2} \mathrm{CN}_{2}$ a 1 e $2 \%$ e pela $\mathrm{CaCN}_{2}$ a $20 \% . \mathrm{H}_{2} \mathrm{CN}_{2}$ a 2 e $3 \%$ também induziram grande número de cachos, sem superar, no entanto, $\mathrm{H}_{2} \mathrm{CN}_{2}$ a 4 e $5 \%$.

Com exceção de $\mathrm{H}_{2} \mathrm{CN}_{2}$ a $6 \%$, o qual induziu o menor peso de cacho, todos os demais tratamentos equivaleram-se estatisticamente nesta caracteristica.

As maiores produções foram obtidas com $\mathrm{H}_{2} \mathrm{CN}_{2}$ a 1,2 , e $3 \%$ e com $\mathrm{CaCN}_{2}$ a $20 \%$. As menores foram obtidas com $\mathrm{H}_{2} \mathrm{CN}_{2}$ a 4,5 e $6 \%$.

Devido às diferenças observadas entre as doses de $\mathrm{H}_{2} \mathrm{CN}_{2}$, partiu-se para seu estudo isolado no Experimento 1 (A.2).

\subsubsection{Experimento 1 [Anáise de Variância 2 (A.2)].}

Este experimento avaliou o efeito de doses crescentes de cianamida hidrogenada nas concentrações de 1,0 a $6,0 \%$ na poda realizada em $16 / 8 / 91$.

A tabela 19 mostra que ocorreram diferenças significativas entre as doses crescentes de $\mathrm{H}_{2} \mathrm{CN}_{2}$ para todas as características estudadas.

Por seu lado, na figura 8 é mostrado que houve um efeito linear decrescente com o aumento da concentração de cianamida para os dados de brotação da gema principal.

Na figura 9 , verifica-se que a porcentagem de brotação de gemas velhas respondeu de forma quadrática à aplicação de doses crescentes de $\mathrm{H}_{2} \mathrm{CN}_{2}$. A curva ajustada indica que a maior porcentagem de brotação das gemas velhas ocorreu à concentração de $4,89 \%$. 
A porcentagem de brotação total decresceu linearmente com o aumento da concentraçăo de $\mathrm{H}_{2} \mathrm{CN}_{2}$, conforme se nota na figura 10 . 


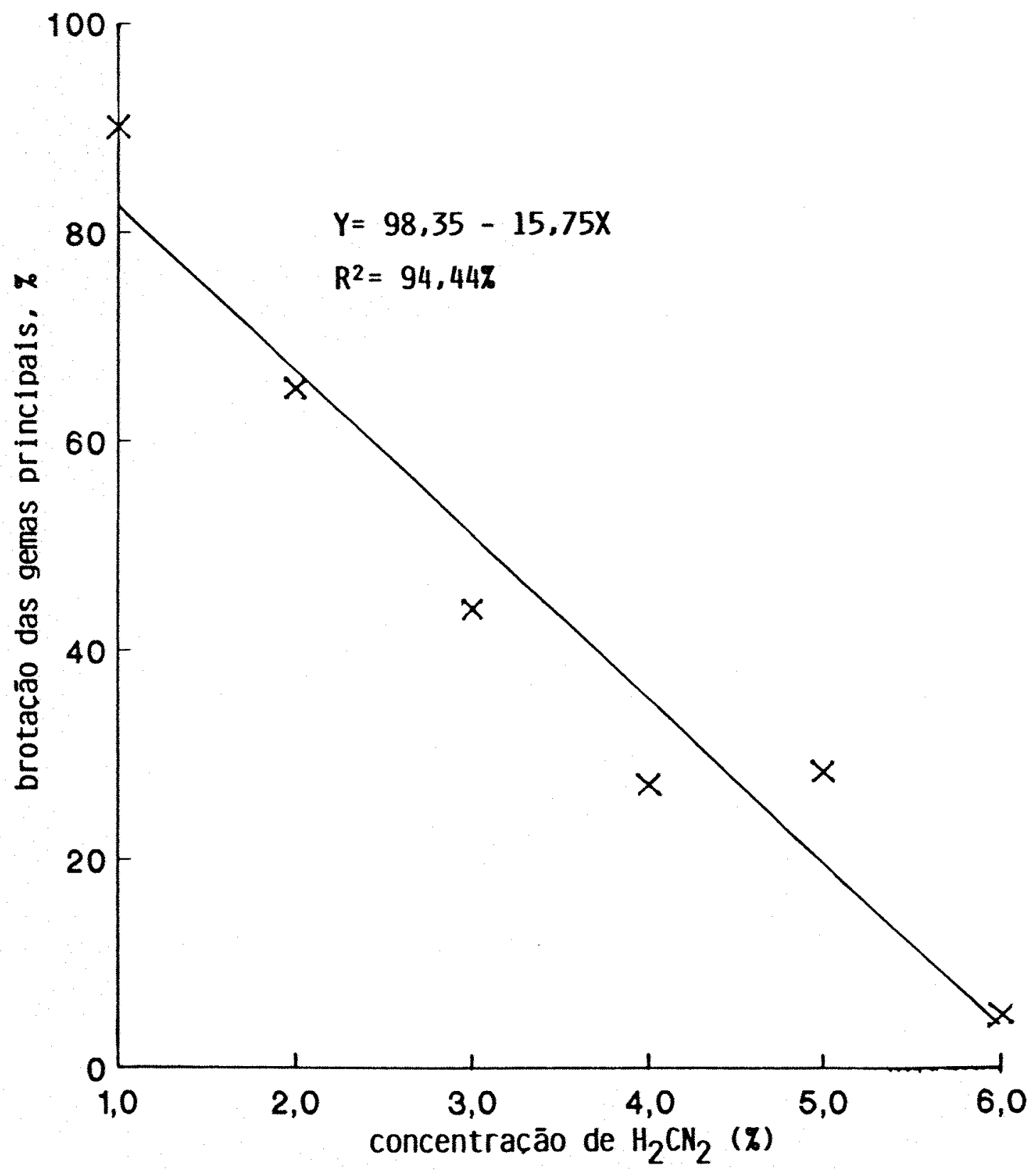

Figura 8. Efeito de concentracōes crescentes de $\mathrm{H}_{2} \mathrm{CN}_{2}$ na porcentagem de brotação das gemas principais (dados transformados em arc sen $\sqrt{x}$ ) da videira Niagara Rosada. São Miguel Arcanjo. 1991. 


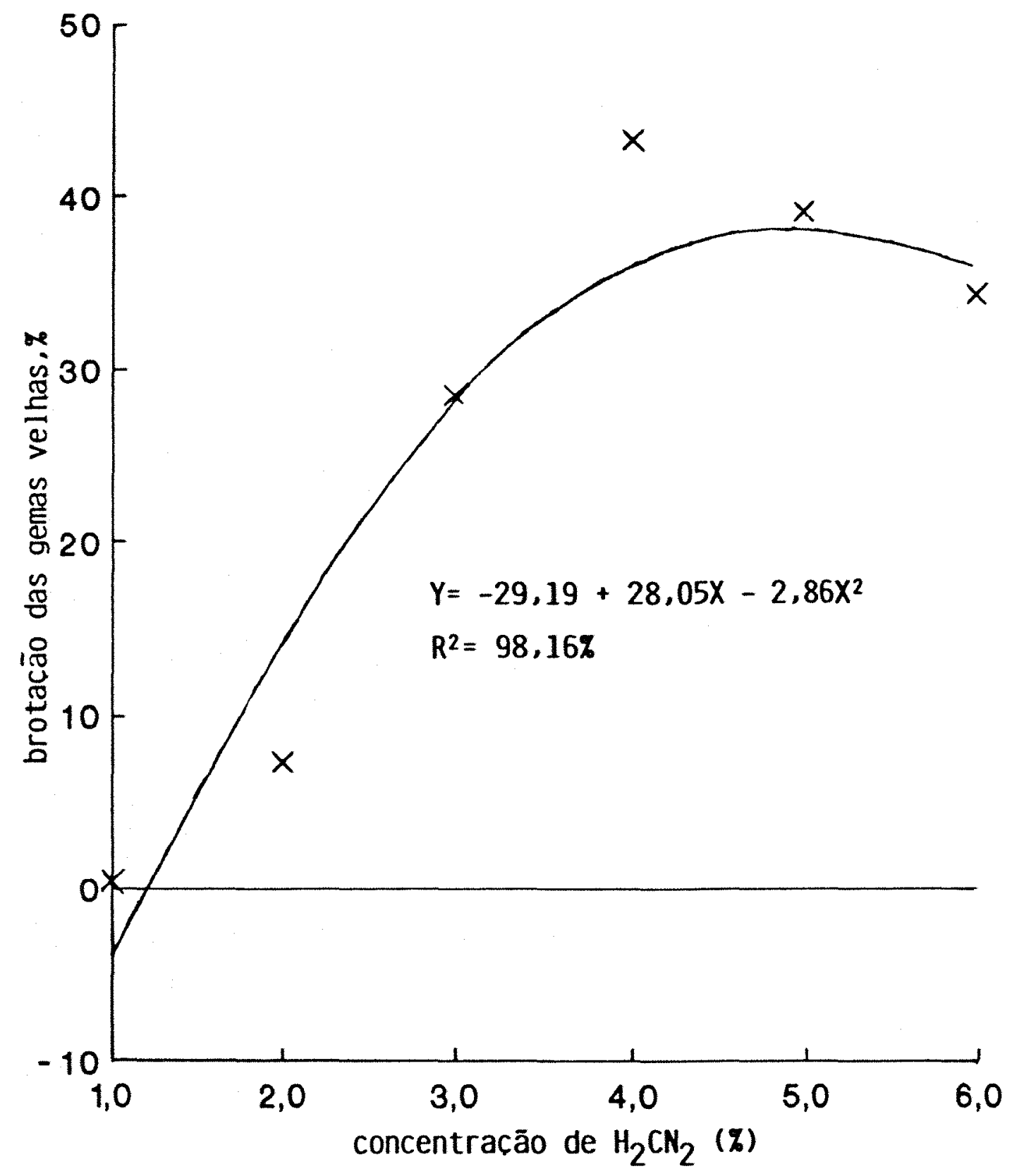

Figura 9. Efeito de concentracōes crescentes de $\mathrm{H}_{2} \mathrm{CN}_{2}$ na porcentagem de brotaçāo das gemas velhas (dados transformados em arc sen $\sqrt{x}$ ) da videira Niagara Rosada. São Miguel Arcanjo. 1991. 


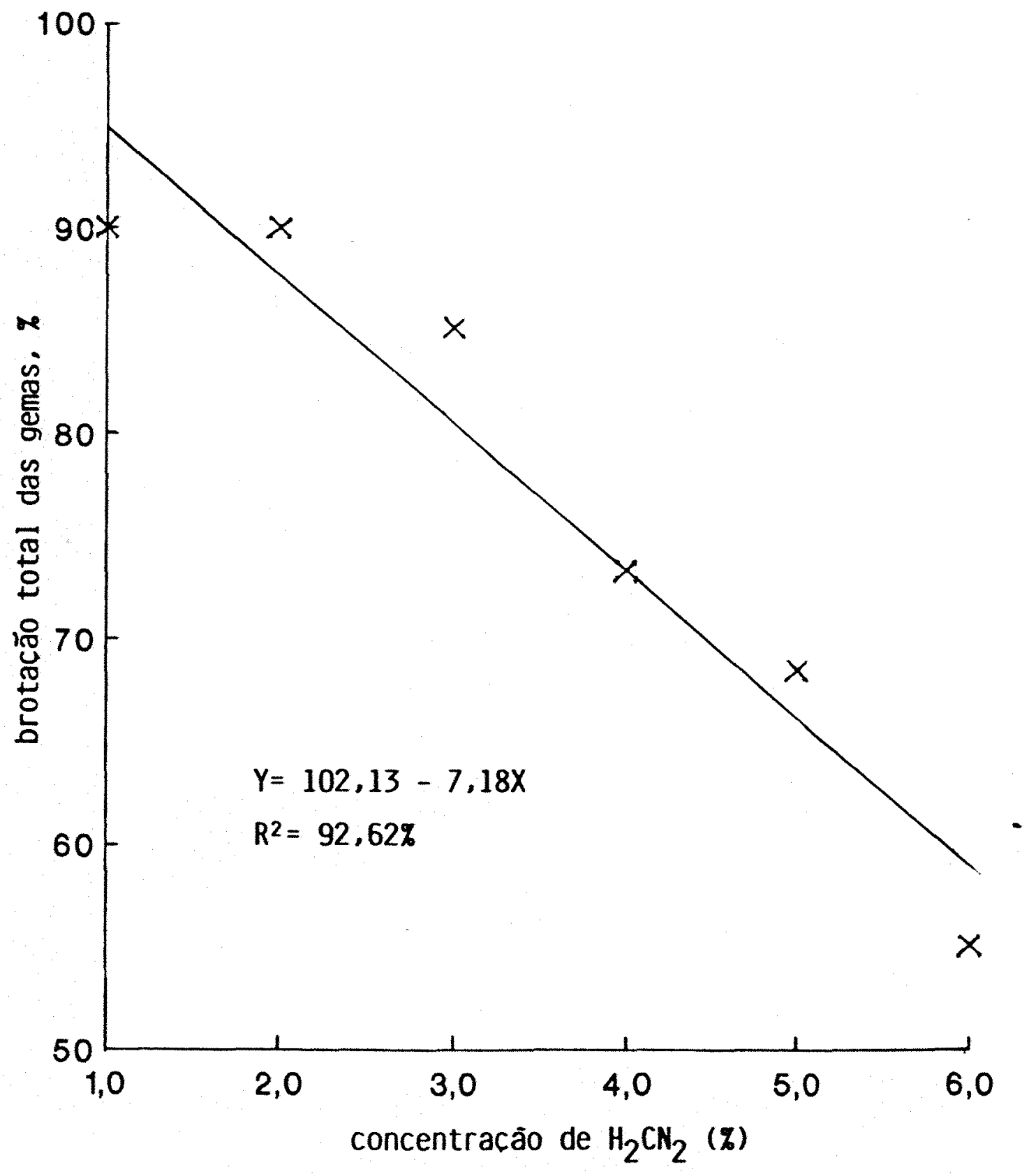

Figura 10. Efeito de concentraçōes crescentes de $\mathrm{H}_{2} \mathrm{CN}_{2}$ na porcentagem de brotaçāo total de gemas (dados transformados em arc sen $\sqrt{x}$ ) da videira Niagara Rosada. São Miguel Arcanjo. 1991. 


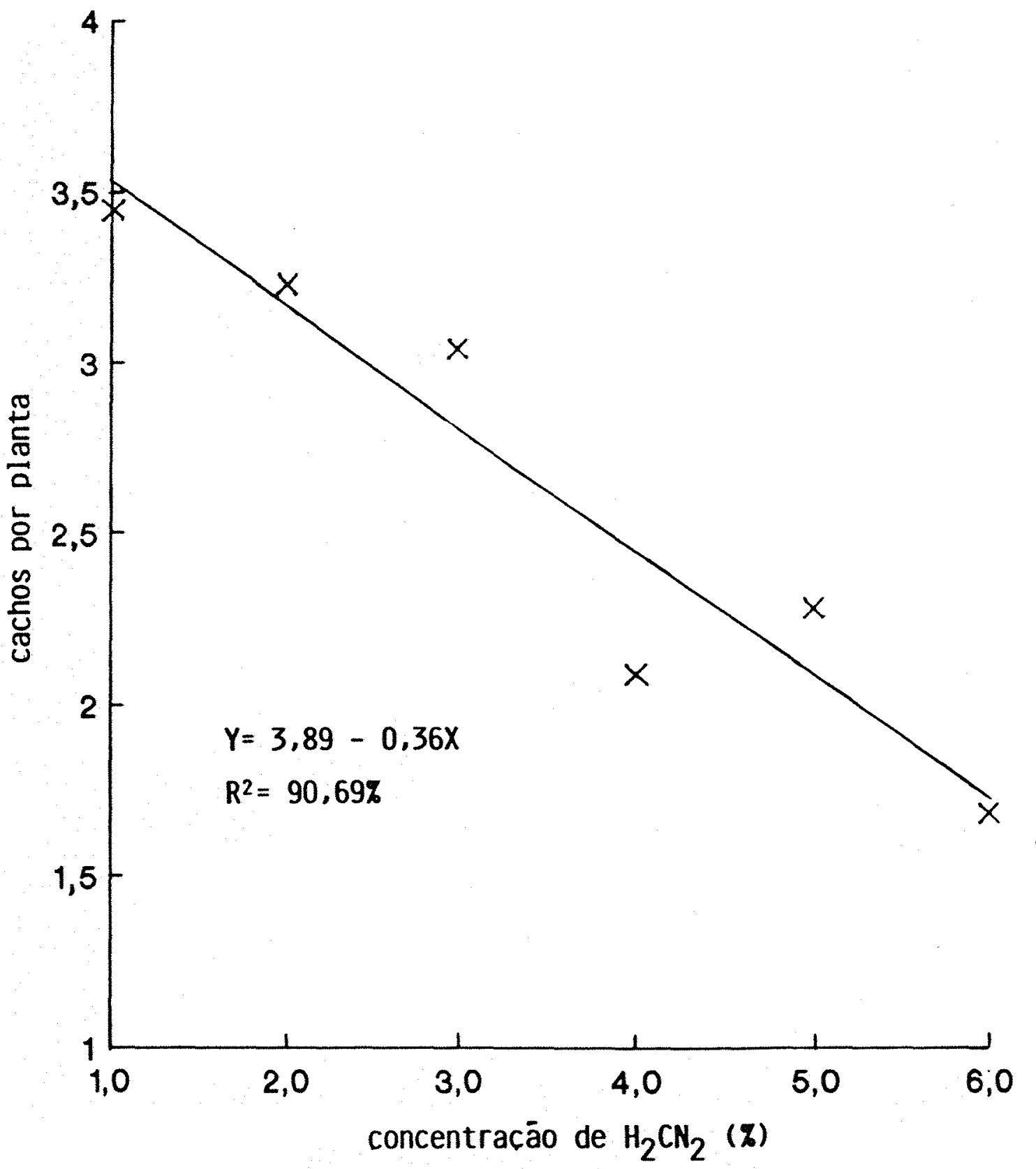

Figura 11. Efeil to de concentraçōes crescentes de $\mathrm{H}_{2} \mathrm{CN}_{2}$ no número de cachos por planta (dados transformados em $\sqrt{x}$ ) da videira Niagara Rosada. Sāo Miguel Arcanjo. 1991. 


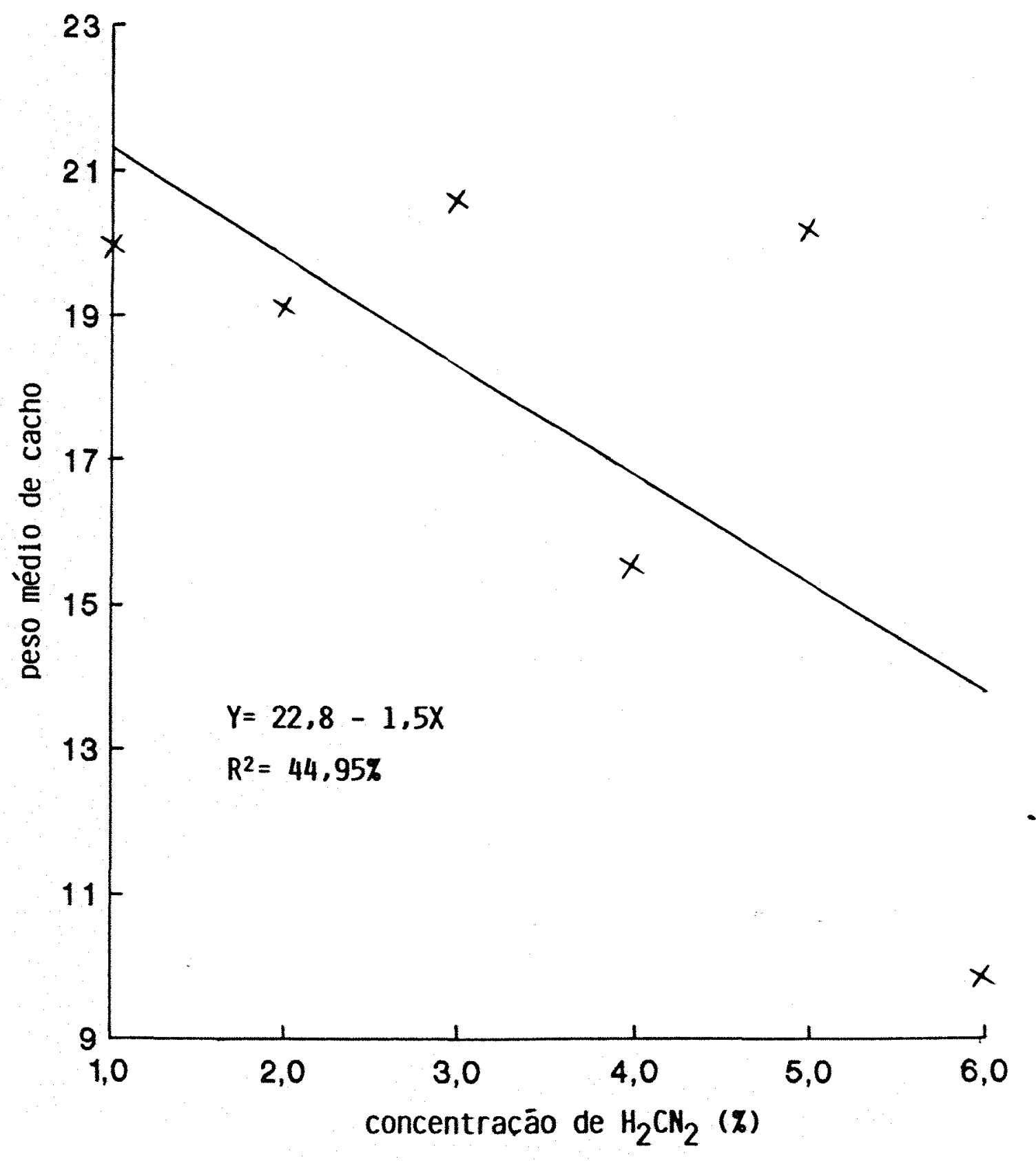

Figura 12. Efeil to de concentraçōes crescentes de $\mathrm{H}_{2} \mathrm{CN}_{2}$ no peso médio de cacho (dados transformados em $\sqrt{x}$ ) da Videira Niagara Rosada. Săo Miguel Arcanjo. 1991. 


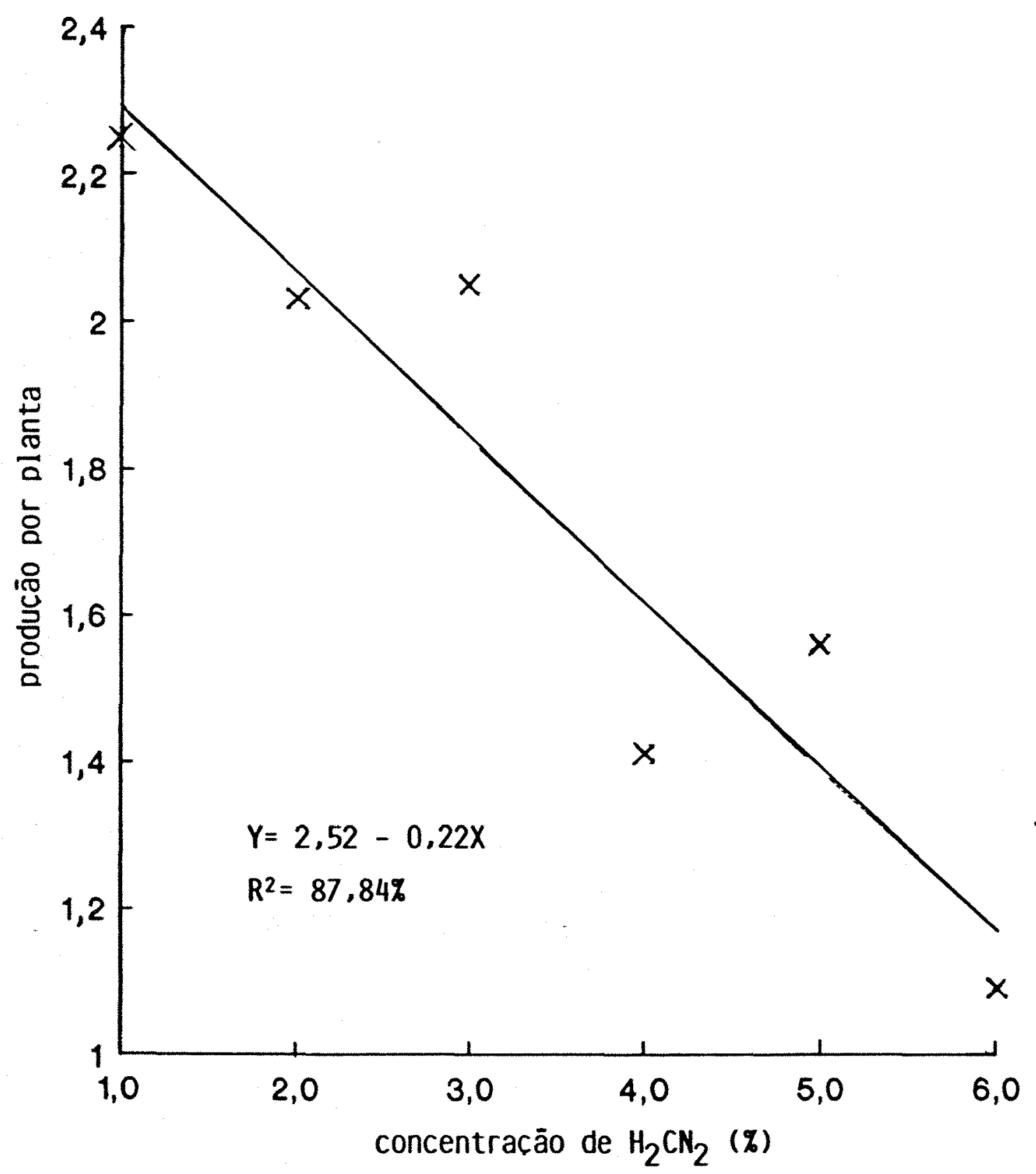

Figura 13. Efeito de concentraçôes crescentes de $\mathrm{H}_{2} \mathrm{CN}_{2}$ na producão por planta (dados transformados em $\sqrt{x}$ da videira Niagara Rosada. São Miguel Arcanjo. 1991. 


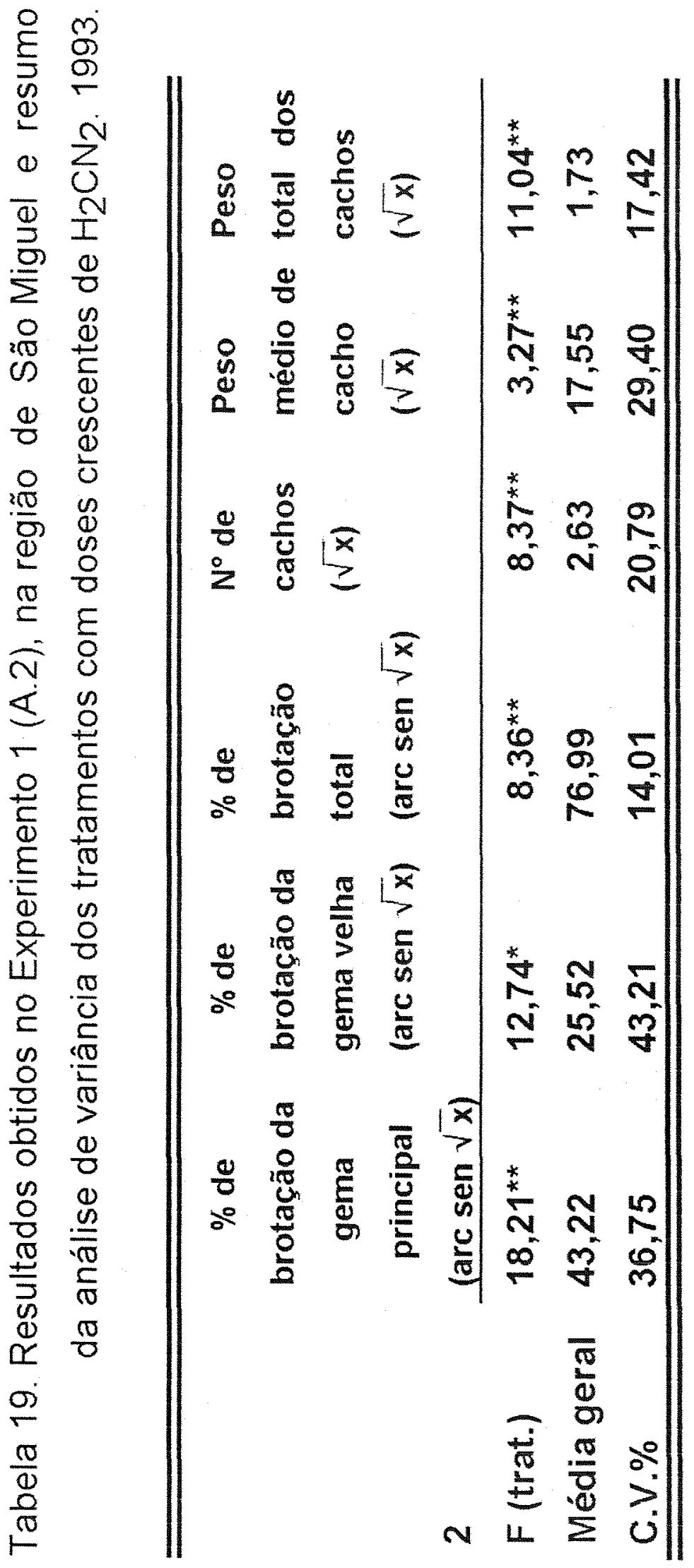


As Figuras 11, 12. e 13 que tratam dos fatores de produção do experimento, demonstram que com 0 aumento na concentração de $\mathrm{H}_{2} \mathrm{CN}_{2}$ a 8produçăo foi reduzida linearmente.

O experimento 1 (Análise de Variancia 1) mostrou que a aplicação de $\mathrm{CaCN}_{2} 20 \%$ e $\mathrm{H}_{2} \mathrm{CN}_{2} 1$ a $6 \%$ exibiram resultados semelhantes do ponto de vista estatístico.

Para o parâmetro brotação da gema principal, que é a gema que sobrou da poda do ramo do ano, $\mathrm{CaCN}_{2} \quad 20 \%$ e $\mathrm{H}_{2} \mathrm{CN}_{2} \quad 1 \%$ foram estatisticamente semelhantes, entretanto $\mathrm{H}_{2} \mathrm{CN}_{2} 1 \%$ mostrou certa superioridade em condiçøes de campo pois induziu a brotaçăo de $100 \%$ das gemas, enquanto que com $\mathrm{CaCN}_{2} 20 \%$ a brotação da gema principal ficou em média com $89,28 \%$. No que diz respeito à porcentagem de brotação de gemas velhas, nota-se que a $\mathrm{CaCNa}_{2} 20 \%$ e $\mathrm{H}_{2} \mathrm{CN}_{2} 1 \%$ e $2 \%$ são pouco efetivas, acontecendo o contrário com doses mais elevadas de $\mathrm{H}_{2} \mathrm{CN}_{2}$, o que de certo ponto compensaria em termos de porcentagem de brotação os danos causados as gemas do ano. No entanto concentrações muito elevadas, de 6 a $12 \%$, foram letais até para a brotação das gemas velhas.

No experimento 1 (Análise de Variância 2), concentraçőes acima de $2 \%$ de $\mathrm{H}_{2} \mathrm{CN}_{2}$ aplicadas nas videiras dessa região causaram um efeito desastroso nesse tipo de gema principal, que aliás é a mais importante para a produtividade da planta por ser mais vigorosa e bem desenvolvida. As gemas que não brotaram com concentraçōes acima de $2 \%$ de $\mathrm{H}_{2} \mathrm{CN}_{2}$ estavam mortas, o que confere com os dados obtidos por KUROI (1985) que em época de poda normal verificou que concentração acima de $2 \%$ provocou danos letais às gemas, e em poda tardia, quando a planta já teve sua dorméncia quebrada pelo frio, cianamida em concentração superior a $1 \%$ causou injúria química às gemas. Danos letais às gemas também foram observados por outros pesquisadores como BRACHO et al. (1984) com dose acima de 6\% em 'Cabernet Sauvignon'; WHITING \& COOMBE (1984), com doses superiores a $2,5 \%$ nos cvs. Sultana e Cabernet Sauvignon; MIELE (1991) com dose de $\mathrm{H}_{2} \mathrm{CN}_{2}$ acima de $1,9 \%$. Já SILLER-CEPEDA et al. (1994) não encontraram sintoma de fitotoxicidade nem a concentrações muito elevadas como $8 \%$, mas no entanto estes autores verificaram que com esta concentração houve tendência em reduzir e atrasar a quebra de dormência das gemas da videira 'Perlette'. 
Com a boa brotação das gemas principais, e considerando ainda que em muitas delas também brotaram a primária e a secundária (dado também observado por CASTERAN, 1987), verificou-se nesse experimento, nas duas formas de análise de variancia, que as melhores concentraçסes para a calciocianamida e a cianamida hidrogenada foram $20 \%$ e $1 \%$ respectivamente, e o emprego de um ou de outro está em função do custo do produto, o que coincide com a opinião de ALBUQUERQUE \& SOBRAL (1989).

\subsubsection{Experimento 2}

$\mathrm{Na}$ poda realizada em 13/08/92, com $\mathrm{H}_{2} \mathrm{CN}_{2} 1,0 ; 1,25 ; 1,5$; 1,75 e $2,0 \%$, a porcentagem de brotação foi de $100 \%$ em todos os tratamentos, e a produção mostrada na tabela 20 indica que não houve diferença do ponto de vista estatístico entre as concentrações para os parâmetros estudados. Estes resultados são muito semelhantes aos do experimento realizado no ano anterior para as concentrações de $\mathrm{H}_{2} \mathrm{CN}_{2}$.

Tabela 20. Resultados obtidos no Experimento 2 na região de São Miguel Arcanjo e resumo da análise de variância dos tratamentos com doses crescentes de $\mathrm{H}_{2} \mathrm{CN}_{2} \cdot 1992$

\begin{tabular}{lccc}
\hline & $N^{\circ}$ de cachos & Peso de cacho & Peso total \\
\cline { 2 - 4 }$F$ (trat.) & 1,43 & 0,99 & 0,77 \\
Média geral & 3,67 & 177,53 & 2,03 \\
C.V. \% & 11,51 & 6,68 & 16,42 \\
\hline \hline
\end{tabular}




\section{CONCLUSÓES}

Nas condições experimentais em que foi realizado o presente trabalho, pode-se tirar as seguintes conclusões:

\subsection{Região de Jundiaí}

a) Pulverização de $\mathrm{H}_{2} \mathrm{CN}_{2} 1 \%, 2 \%, 3 \%$ e $4 \%$ sobre o cordăo esporonado ou pincelamento das gemas com $\mathrm{CaCN}_{2} 20 \%$ imediatamente após a poda, apresentaram resultados semelhantes em podas realizadas desde o começo de julho até meados de agosto, na antecipação da brotaçăo, porcentagem de brotação de gemas e diminuição do ciclo da videira Niagara Rosada. Para podas tardias, realizadas em setembro, os compostos químicos nåo foram eficientes para as características acima descritas, comportando-se de modo semelhante à testemunha não tratada. Quanto à produção, nas podas mais precoces (até 20 de julho) houve resposta positiva e semelhante entre os compostos utilizados. De modo geral, a partir de agosto a produção de uva não foi influenciada pela aplicação dos compostos químicos

b) A pulverização de doses crescentes de $\mathrm{H}_{2} \mathrm{CN}_{2}$ de $0 \%$; $1,25 \% ; 1,5 \% ; 1,75 \%$ e $2 \%$ produziu um efeito altamente positivo na antecipaçáo da brotaçăo, no aumento do número de gemas brotadas, na diminuiçăo do ciclo, no aumento do número de cachos e na produção por planta. $A$ análise de regressão polinomial mostrou que houve um efeito quadrático positivo, e os pontos de mínimo para a característica número de dias para brotar, e os de máximo para as demais foram obtidos nas concentraçz̃es de $1,46 \% ; 1,44 \% ; 1,63 \% ; 1,63 \% ; 1,63 \%$ respectivamente.

\subsection{Região de Indaiatuba}

a) Pulverização de nitrato de potássio mais nitrato de cálcio, associados ou não à calciocianamida $5 \%$ sobre o cordão esporonado, imediatamente após a poda, não foi eficiente na quebra de dormência de gemas. 
b) A cianamida hidrogenada, independentemente da concentraçăo, mostou efeito positivo na antecipaçăo da brotaçăo em relaçăo à testemunha não tratada.

c) Para videiras velhas a pulverização do cordăo esporonado com $\mathrm{H}_{2} \mathrm{CN}_{2}$ a 1 ou $2 \%$ ou pincelamento com $\mathrm{CaCN}_{2} 20 \%$, imediatamente após a poda, apresentaram resultados semelhantes na antecipação da brotação e diminuição do ciclo da videira.

d) Para videiras jovens, em poda realizada em meados do inverno, $\mathrm{a} \mathrm{H}_{2} \mathrm{CN}_{2}$ nas concentrações de 1,0 a $1,5 \%$ foi tão eficiente quanto $\mathrm{CaCN}_{2}$ a $20 \%$ na antecipação da brotação. Entretanto, na diminuição do ciço, $\mathrm{H}_{2} \mathrm{CN}_{2}$ de 1,25 a $2,0 \%$ foi superior a $\mathrm{CaCN}_{2}$ a $20 \%$. A porcentagem de brotação e a produção nåo foram afetadas pelos tratamentos.

e) $\mathrm{A}_{2} \mathrm{CN}_{2}$ nas concentraçóes de $0 ; 1,0 ; 1,25 ; 1,5 ; 1,75$ e $2 \%$ teve um efeito altamente positivo sobre as características número de dias para brotar e diminuição do ciclo da videira. Este efeito foi de segundo grau de acordo com a análise de regressão polinomial.

\subsection{Região de São Miguel Arcanjo}

a) A pulverização de $\mathrm{H}_{2} \mathrm{CN}_{2} 1 \%$ sobre o cordão esporonado ou o pincelamento das gemas da videira com $\mathrm{CaCN}_{2} 20 \%$, imediatamente após a poda realizada em 13 de agosto de 1991 foram eficientes na quebra de dormência e brotação das gemas principais, na porcentagem de brotação e na produção da videira Niagara Rosada.

b) A aplicação de $\mathrm{H}_{2} \mathrm{CN}_{2}$ em concentraçōes acima de $1 \%$, provocaram danos às gemas produtivas do ano, induzindo a brotação de gemas velhas do cordão esporonado, com consequiente diminuiçăo da produção.

\subsection{Geral}

De modo geral, pode-se concluir que a calciocianamida a $20 \%$ e a cianamida hidrogenada tiveram o mesmo efeito positivo para as características avaliadas nas três regiôes sempre dependendo da concentração de $\mathrm{H}_{2} \mathrm{CN}_{2}$. Para a regiăo de Jundiai, a concentração de cianamida recomendada situou-se na faixa de 1,44 a $1,63 \%$; para Indaiatuba na faixa de 1,25 a $1,66 \%$; e finalmente para Săo Miguel Arcanjo na concentração de $1 \%$. 


\section{REFERÊNCIAS BIBLIOGRÁFICAS}

AHMEDULLAH, M.; KAWAKAMI, A.; SANDIDGE, C.R.; WAMPLE, R.L. Effect of paclobutrazol on the vegetative growth, yield, quality, and winterhardiness of buds of 'Concord' grape. HortScience, Alexandria, 21(2):273-274, 1986.

ALBUQUERQUE, J.A.S. \& ALBUQUERQUE, T.C.S. Uso de produtos químicos na quebra de dorméncia de gemas da videira do sub-médio Săo Francisco. In: CONGRESSO BRASILEIRO DE FRUTICULTURA. 7., Florianópolis, 1983, Anais. Florianópolis, Sociedade Brasileira de Fruticultura/Empresa de Pesquisa Agropecuária de Santa Catarina, 1984. v. 4 p. 1188-1199.

ALBUQUERQUE, J.A.S.; ALBUQUERQUE, T.C.S.; SOBRAL, S.M.N. Efeito da calciocianamida na brotaçăo da videira (Vitis vinifera L.) na região do submédio São Francisco. In: CONGRESSO BRASILEIRO DE FRUTICULTURA. 8., Brasilia, 1986, Anais. Brasilia, EMBRAPACNPq, 1986. v. 2 p. $479-483$

ALBUQUERQUE, J.A.S. \& SOBRAL, S.M.N. Efeito de alguns produtos químicos na brotação da videira Pirovano 65 na região semiárida do vale do São Francisco. In: CONGRESSO BRASILEIRO DE FRUTICULTURA. 10., Fortaleza, 1989, Anais. Fortaleza, Sociedade Brasileira de Fruticultura, 1989. p. $475-479$.

AMBERGER, A. Uptake and metabolism of hydrogen cyanamide in plants. In: INTERNATIONAL SEMINAR OF BUD DORMANCY IN GRAPEVINES: POTENTIAL AND PRACTICAL USES OF HYDROGEN CYANAMIDE ON GRAPEVINES, Davis, 1984, Proceedings. Davis, University of California, 1984. p. 5-10. 
AERO CYANAMIDE - What it is/How to use it. s.d. American Cyanamide Company. Agricultural Chemicals Division. 30 Rockefeller Plaza. New York 20, New York.

ANUÁRIO ESTATÍSTICO DO BRASIL -1993, Rio de Janeiro, 52.

BAGGIOLINI, M. Les stades repères dans le développement annuel de la vigne. Revue Romande d'Agriculture de Viticulture et d'Arboriculture, 8:4-6, 1952.

BRACHO, E.; JOHNSON, J.O.; WICKS, A.S.; LIDER, L.A.; WEAVER, R.J. Using hydrogen cyanamide to promote uniform budbreak in Cabernet Sauvignon in California: preliminary results. In: INTERNATIONAL SEMINAR OF BUD DORMANCY IN GRAPEVINES: POTENTIAL AND PRACTICAL USES OF HYDROGEN CYANAMIDE ON GRAPEVINES, Davis, 1984, Proceedings. Davis, University of California, 1984. p. 11-14.

BONNAIRE, A. \& RIEDER, G. Cianamida hidrogenada: un nuevo regulador de crecimiento para uva de mesa. Aconex, Santiago, 9:21-22, 1985.

CASTERAN, P. Influence de la cyanamide hydrogenè sur le débourrement et la production du cepage Cabernet-Sauvignon dans le vignoble de Bordeaux. in: SYMPOSIUM INTERNATIONAL SUR LA PHYSIOLOGIE DE LA VIGNE. 3., Bordeaux, 1986, Comptes Rendus, Paris, Office International de la Vigne et du Vin, 1987. p. 81-85.

EMMERSON, J.G. \& POWELL, L.E. Endogenous abscisic acid in relation to rest and bud burst in three Vitis species. J. Amer. Soc. Hort. Sci., Mount Vernon, 103(5):677-688, 1978.

EREZ, A. \& LAVEE, S. Recent advances in breaking the dormancy of deciduous fruit trees. In: INTERNATIONAL HORTICULTURAL CONGRESS, XIX., Varsóvia, 1974, Proceedings. Varsóvia, International Society for Horticultural Science, 1974. p. 69-78. 
FOOT, J.H. Effect of hydrogen cyanamide on bud emergence in wine grapes. Calif. Agric., Berkeley, 41(3/4):19, 1987.

GALLI, F.; TOKESHI, H.; CARVALHO, P.C.T; BALMER, E.; KIMATI, H.; CARDOSO, C.O.N.; SALGADO, C.L. Doenças da videira. In: Galli, F., coord. Manual de Fitopatologia. São Paulo, Ed. Agronômica Ceres, 1968, p. 456-69.

HATCH, R.L. \& RUIZ, M. Influence of pruning date on budbreak of desert table grapes. Am. J. Enol. Vitic., Davis, 38(4):326-328, 1987.

HOPPING, M.E. Effect of growth regulators and dormancy-breaking chemicals on bud break and yield of 'Palomino' grape vines. New Zealand J. Exp. Agric., Auckland, 5:339-343, 1977. Apud Horticultural Abstracts, London, 48(9):710$711,1978$.

IWASAKI, K. Effects of bud scale removal, calcium cyanamide, $\mathrm{GA}_{3}$, and ethephon on bud break of 'Muscat of Alexandria' grape (Vitis vinifera L.). Journal of Japanese Society for Horticultural Science, Tokyo, 48(4):395-398, 1980.

JENSEN, F. \& BETTIGA, L. The effect of hydrogen cyanamide on bud break of Thompson Seedless, Emperor, and French Colombard. In: INTERNATIONAL SEMINAR OF BUD DORMANCY IN GRAPEVINES: POTENTIAL AND PRACTICAL USES OF HYDROGEN CYANAMIDE ON GRAPEVINES, Davis, 1984, Proceedings. Davis, University of California, 1984. p. 15-16.

KISHINO, A.Y.; MASHIMA, M; CARVALHO, S.L.C; NASCIMENTO, E.C.; CAETANO, A. Efeito da calciocianamida na brotação da videira cultivar ltália (Pirovano 65). In: CONGRESSO BRASILEIRO DE FRUTICULTURA, 4., Salvador, 1977. Anais. Cruz das Almas, Sociedade Brasileira de Fruticultura, 1978. p.315-321.

KUROI, I. Effects of calcium cyanamide and cyanamide on bud break of 'Kyoho' grape. Journal Japan Soc. Hort. Sci., Tokyo, 54:301-306, 1985. 
KUROI, I.; SHIRAISHI, Y,; IMANO, S. Studies on breaking the dormancy of grapevines. 1. Effect of lime nitrogen treatments for shortening the rest period of glasshouse grown grapevine. Journal Japan Soc. Hort. Sci., Tokyo, 32:175$180,1963$.

LAVEE, S. Dormancy and break in warm climates; consideration of growth regulator involvement. Acta Hortic., Amsterdan, 34:255-264, 1973.

LIN, C.H. \& WANG, T.Y. Enhancement of bud sprouting in grape single bud cuttings by cyanamide. Am. J. Enol. Vitic., Davis, 36(1):15-17, 1985.

LIN, C.H.; LIN, H.S.; LIN, J.H.; LIAW, W.J.; CHANG, L.R. The appplication of cyanamide on termination of dormancy in Kyoho grapevine bud. National Science Council Monthly, Coréia, XI(4):291-299, 1983.

LIN, C.H.; LIN, J.H.; CHANG, L.R.; LIN, H.S. The regulation of the Golden Muscat grape production season in Taiwan. Am. J. Enol. Vitic., Davis, 36(2):114-1 17, 1985.

LUVISI, D.A. The evaluation of hydrogen cyanamide, Kern County, 1984. In: INTERNATIONAL SEMINAR OF BUD DORMANCY IN GRAPEVINES: POTENTIAL AND PRACTICAL USES OF HYDROGEN CYANAMIDE ON GRAPEVINES,Davis, 1984, Proceedings. Davis, University of California, 1984.p. 36-39.

MIELE, A. Efeito da cianamida hidrogenada na quebra de dorméncia das gemas, produtividade do vinhedo e composição química do mosto da uva Cabernet Sauvignon. Pesq. Agropec. Bras., Brasilia, 26(3):315-324, 1991.

MIELE, A; IGNACZAK, J.C.; PEREIRA, F.M. Efeito da calciocianamida na quebra de dormenncia, fertilidade das gemas, produtividade do vinhedo e qualidade da uva Cabernet Franc. Pesq. Agropec. Bras., Brasilia, 17(3):393-398, 1982. 
MURISIER, F.; JELMINI, J.; FERRETTI, M.; MADONNA, A. Amélioration du débourrement du Merlot au moyen de la cyanamide hydrogene. Revue Suisse Vitic. Arboric. Hortic., Nyon, 22(6):399-402, 1990.

NIR, G.; SHULMAN, Y.; FANBERSTEIN, L.; LAVEE, S. The involvement of catalase in the dormancy of grapevine buds. In: INTERNATIONAL SEMINAR OF BUD DORMANCY IN GRAPEVINES: POTENTIAL AND PRACTICAL USES OF HYDROGEN CYANAMIDE ON GRAPEVINES, Davis, 1984, Proceedings. Davis, University of California, 1984. p. 40-43.

NIR, G.; SHULMAN, Y.; FANBERSTEIN, L.; LAVEE, S. Changes in the activity of catalase (EC 1.11.1.6) in relation to the dormancy of grapevine (Vitis vinifera L.) buds. Plant. Physiol., Lancaster, 81:1140-1142, 1986.

OSÓRIO, G.; SILLER-CEPEDA, J.; BÁEZ, M.; SANCHEZ, A. High temperatures during dormancy influenced budbreak of table grapes cV. Flame Seedless. HortScience, Alexandria, 28(5):586, 1993.

PEREIRA, F.M. \& OLIVEIRA, J.C. Efeitos de diferentes formas de aplicação de calciocianamida sobre a antecipaçăo da brotação e da época de produção da cultivar de videira Niagara Rosada. Científica. Jaboticabal, 6(2):203-207, 1978.

PEREIRA, F.M.; SIMÃO, S.; MARTINS, F.P.; LOWLER, P.; IGUE, T. Ação da calciocianamida e da giberelina na antecipação da maturaçăo dos frutos do cultivar de videira Niagara Rosada. Científica, Jaboticabal, 7(3):411-415, 1979.

PIRES, E.J.P.; CASTRO, P.R.C.; DEMÉTRIO, C.G.D. Ação da calciocianamida e alzodef na época de brotação e produtividade da videira 'Niagara Rosada'. Anais da Escola Superior de Agricultura "Luiz de Queiroz". Piracicaba, XLII(2):469-479, 1985.

PIRES, E.J.P. \& TERRA, M.M. Uvas. In: Plante no Sítio. Săo Paulo. Editora Três, 1987.66p. 
PIRES, E.J.P.; TERRA, M.M.; POMMER, C.V.; PASSOS, I.R.S.; NAGAI, V. Effect of increasing concentrations of hydrogen cyanamide in breaking bud dormancy and in the yield of grapevine Italia (Vitis vinifera L.). Bulletin de l'O.I.V. Revue Internationale, Paris, 66(747-748):348-363, 1993.

POMMER, C.V.; PASSOS, I.R.S.; TERRA, M.M.; PIRES, E.J.P. Variedades de videira para o Estado de São Paulo. Campinas. Instituto Agronômico. Boletim. (No prelo).

PONI, S.; FILIPPETTI, I; ZANOTTI, A. Effects of dormex applications on Vitis vinifera (cv. Sangiovese) in a cold winter area. Advances in Horticultural Sciences, Bologna, 4(2):121-126, 1990.

POUGET, R. Recherches physiologiques sur le repos vegetatif de la vigne (Vitis vinifera L.): La dormance des bourgeons et le mécanisme de sa disparation. Annales de l'Amelioration des Plantes, Paris, 13:247, 1963.

REDDY, N.N. \& SHIKHAMANY, S.D. Effect of hydrogen cyanamide and thiourea on budbreak and bloom of Thompson Seedless grapevines under tropical conditions. Crop. Res., Hisar, 2(2):163-168, 1989.

SETZER, J. Atlas Climático e Ecológico do Estado de São Paulo. São Paulo, Instituto Geológico e Geográfico, 1966, 61p.

SHIKHAMANY, S.D.; PRAKASH, G.S.; REDDY, N.N. Effect of certain chemicals and cane twisting on bud break in Thompson Seedless grape. Crop Res., Hisar, 2(1):1-7, 1989.

SHULMAN, Y.; NIR, G.; FANBERSTEIN, L.; LAVEE, S. The effect of cyanamide on the release from dormancy of grapevine buds. Scientia Horticulturae, Amsterdan, 19:97-104, 1983.

SHULMAN, Y.; NIR, G.; , LAVEE, S. Oxidative processes in bud dormancy and the use of hydrogen cyanamide in breaking dormancy. Acta Hortic., Amsterdan, 179:141-148, 1986. 
SILLER-CEPEDA, J.; OSORIO, G.; BÁEZ, M.; SANCHES, A.; AVALOS, J. Chilling requirement and budbreak response to hydrogen cyanamide in Flame Seedless' grapes. HortScience, Alexandria, 28(5):586, 1993.

SILLER-CEPEDA, J.H.; OSORIO, G; SANCHEZ, A.; BÁEZ, M.; GARDEA, A.; BAEZ, R.; CRISOTO, C.H. Managing harvest date by breaking dormancy at different bud physiological stages. In: INTERNATIONAL SYMPOSIUM ON TABLE GRAPE PRODUCTION, Anaheim (USA), 1994, Proceedings. Davis, American Society for Enology and Viticulture, 1994. p. 102-108.

SIMANCAS, R.; CORZO, P.; BRACHO, E. Evaluation of different methods to improve budbreak and fertility of three grape cultivars. Acta Horticulturae, Amsterdan, 199:100, 1987.

SITUATION de la viticulture dans le monde en 1993. Bulletin de I'O.I.V. Revue Internationale, Paris, 66(753-754):896-943, 1993.

SNIR, I. Chemical dormancy breaking of red raspberry. HortScience, Alexandria, 18(5):710-713, 1983.

TERRA, M.M.; FAHL, J.I; PIRES, E.J.P.; PASSOS, I.R.S.; MARTINS, F.P.; CARELLI, M.L.C. Efeitos de doses e modos de aplicação de calciocianamida na brotação e na produção de videira 'Niagara Rosada' (Vitis labrusca L. X Vitis vinifera L.). In: SIMPÓSIO LATINO-AMERICANO DE ENOLOGIA E VITICULTURA. JORNADA LATINO-AMERICANA DE VITICULTURA E ENOLOGIA. SIMPÓSIO ANUAL DE VITIVINICULTURA, II, Garibaldi/Bento Gonçalves, 1987, Anais. Garibaldi/Bento Gonçalves, Associaçăo Brasileira dos Técnicos em Viticultura e Enologia. 1987. p. 287-290.

TERRA, M.M.; FAHL, J.I.; RIBEIRO, I.J.A.; MARTINS, F.P.; SCARANARI, H.J. Efeitos da calciocianamida sobre a videira 'Niagara Rosada' (Vitis labrusca L. $x$ Vitis vinifera L.). In: CONGRESS OF THE AMERICAN SOCIETY FOR 8HORTICULTURAL SCIENCE, 29., CONGRESSO BRASILEIRO DE OLERICULTURA, 21, , CONGRESSO DA SOCIEDADE BRASILEIRA DE FLORICULTURA E PLANTAS HORNAMENTAIS, 2., Campinas, 1981 
Proceedings. Campinas, Sociedade Brasileira de Olericultura 1982. p. 473477.

TERRA, M.M.; PIRES, E.J.P.; NOGUEIRA, N.A.M. Tecnologia para produçăo de uva Itália na região noroeste do Estado de São Paulo. Campinas, Coordenadoria de Assistência Técnica Integral, 1993. 51p ilus. (Documento técnico, 97)

WALKER, D.R. \& DONOHO, C.W. Further studies for the effect of gibberellic acid breaking the rest period of young peach and apple trees. Proc. Amer. Soc. Hort. Sci., Alexandria, 74:87-92, 1959.

WALKER, D.R. \& SEELEY, S.D. The rest mechanism in deciduous tree fruits as influenced by plant growth substances. Acta Hortic., Amsterdan, 34:255-234, 1973.

WEAVER, R.J. Prolonging dormancy in Vitis vinifera with gibberellin, Nature, London, 183:214, 1959.

WHITING, J.R. \& COOMBE, B.G. Response of Sultana and Cabernet Sauvignon grapevines to cyanamide. In: INTERNATIONAL SEMINAR OF BUD DORMANCY IN GRAPEVINES: POTENTIAL AND PRACTICAL USES OF HYDROGEN CYANAMIDE ON GRAPEVINES, Davis, 1984, Proceedings. Davis, University of California, 1984. p. 44-47.

WICKS, A.S.; JOHNSON, J.O.; JENSEN, F.; BRACHO, E.; NEJA, R.; LIDER, L.; WEAVER, R.J. Induction of early and more uniform budbreak in Vitis vinifera L. cvs. Perlette, Flame Seedless and Thompson Seedless grapes with hydrogen cyanamide. In: INTERNATIONAL SEMINAR OF BUD DORMANCY IN GRAPEVINES: POTENTIAL AND PRACTICAL USES OF HYDROGEN CYANAMIDE ON GRAPEVINES, Davis, 1984, Proceedings. Davis, University of California, 1984. p. 48-55. 
WILLIANS, L.E. The effect of cyanamide on budbreak and vine development of Thompson Seedless grapevines in San Joaquin Valley of California. Vitis, 26:107-113, 1987.

ZELLEKE, A. \& KLIEWER, W.M. The effects of hydrogen cyanamide on enhancing the time and amount of budbreak in young grape vineyards Am. J. Enol. Vitic., Davis, 40(1):47-52, 1989.

ZIV, M.; MELAMUD, H.; BERNSTEIN, Z.; LAVEE, S. Necrosis in grapevine buds (Vitis vinifera cv. Queen of Vineyards). II Effect of gibberellic acid ( $\mathrm{GA}_{3}$ ) aplication. Vitis, Siebeldingen, 20(2):105-104, 1981. 
APÊNDICE 
Tabela 1. Dados de temperatura (T) e precipitação (PP) do ano de 1992. Jundiai, SP.

\begin{tabular}{lcccr}
\hline \hline Mês & \multicolumn{3}{c}{$T\left({ }^{\circ} \mathrm{C}\right)$} & $P P(\mathrm{~mm})$ \\
\cline { 2 - 4 } & máxima & mínima & média & \\
\hline jan. & 29,6 & 17,8 & 23,7 & 112,7 \\
fev. & 30,0 & 18,0 & 24,0 & 113,0 \\
mar. & 29,1 & 17,6 & 23,3 & 277,7 \\
abr. & 26,6 & 15,5 & 21,0 & 95,0 \\
maio & 25,2 & 15,0 & 20,1 & 91,0 \\
jun. & 25,7 & 13,1 & 19,4 & 1,6 \\
jul. & 24,0 & 11,4 & 17,7 & 26,9 \\
ago. & 24,6 & 12,0 & 18,3 & 32,2 \\
set. & 24,1 & 14,6 & 19,4 & 108,7 \\
out. & 27,4 & 15,9 & 21,6 & 191,8 \\
nov. & 28,0 & 16,7 & 22,3 & 229,8 \\
dez. & 28,8 & 16,0 & 22,4 & 189,0 \\
\hline \hline
\end{tabular}


Tabela 2. Dados de temperatura (T) e precipitação (PP) do ano de 1993. Jundiaí, SP.

\begin{tabular}{lcccr}
\hline \hline Mês & \multicolumn{3}{c}{$T\left({ }^{\circ} \mathrm{C}\right)$} & $\mathrm{PP}(\mathrm{mm})$ \\
\cline { 2 - 4 } & máxima & mínima & média & \\
\hline jan. & 29,3 & 18,5 & 23,9 & 266,5 \\
fev. & 27,5 & 18,1 & 22,8 & 229,3 \\
mar. & 29,4 & 18,2 & 23,8 & 35,0 \\
abr. & 28,7 & 16,5 & 22,6 & 83,2 \\
maio & 24,4 & 13,5 & 18,9 & 106,1 \\
jun. & 22,9 & 11,3 & 16,9 & 51,0 \\
jul. & 25,1 & 12,0 & 18,5 & 10,3 \\
ago. & 24,6 & 10,2 & 17,6 & 35,8 \\
set. & 25,0 & 14,4 & 19,7 & 232,9 \\
out. & 28,3 & 16,0 & 22,1 & 126,7 \\
nov. & 30,2 & 17,5 & 23,8 & 118,4 \\
dez. & 28,9 & 18,2 & 23,6 & 223,8 \\
\hline \hline
\end{tabular}


Tabela 3. Dados de temperatura (T) e precipitação (PP) do ano de 1993. Indaiatuba, SP.

\begin{tabular}{lcccr}
\hline \hline Mês & \multicolumn{3}{c}{$T\left({ }^{\circ} \mathrm{C}\right)$} & \multicolumn{1}{c}{$\mathrm{PP}(\mathrm{mm})$} \\
\cline { 2 - 5 } & máxima & mínima & média & \\
\hline jan. & 29,5 & 19,6 & 24,6 & 204,3 \\
fev. & 27,5 & 18,7 & 23,1 & 340,9 \\
mar. & 29,4 & 18,8 & 24,1 & 122,8 \\
abr. & 28,3 & 17,5 & 22,9 & 85,2 \\
maio & 25,4 & 14,6 & 20,0 & 100,7 \\
jun. & 23,6 & 12,5 & 18,1 & 41,9 \\
jul. & 25,7 & 13,0 & 19,3 & 11,6 \\
ago. & 25,4 & 11,4 & 18,4 & 38,0 \\
set. & 26,4 & 15,3 & 20,9 & 128,5 \\
out. & 29,1 & 17,3 & 23,2 & 67,1 \\
nov. & 31,1 & 19,2 & 25,1 & 106,4 \\
dez. & 29,1 & 19,3 & 24,2 & 200,6 \\
\hline \hline
\end{tabular}


Tabela 4. Dados de temperatura (T) e precipitação (PP) do ano de 1991. São Miguel Arcanjo, SP.

\begin{tabular}{lrrrr}
\hline \hline Mês & \multicolumn{3}{c}{$T\left({ }^{\circ} \mathrm{C}\right)$} & PP $(\mathrm{mm})$ \\
\cline { 2 - 4 } & máxima & mínima & média & \\
\hline jan. & 25,6 & 17,1 & 21,3 & 265,3 \\
fev. & 26,0 & 17,3 & 21,7 & 330,0 \\
mar. & 24,2 & 16,5 & 20,3 & 178,6 \\
abr. & 24,1 & 15,0 & 19,5 & 126,3 \\
maio & 22,3 & 13,9 & 18,1 & 92,9 \\
jun. & 21.7 & 13,4 & 17,5 & 145,4 \\
jul. & 21,5 & 11,5 & 17,0 & 25,5 \\
ago. & 21,3 & 13,4 & 17,3 & 47,7 \\
set. & 21,6 & 12,4 & 17,0 & 122,3 \\
out & 24,9 & 14,5 & 19,7 & 193,4 \\
nov. & 25,1 & 15,6 & 20,3 & 93,3 \\
dez. & 27,0 & 17,3 & 22,1 & 203,0 \\
\hline \hline
\end{tabular}


Tabela 5. Dados de temperatura (T) e precipitação (PP) do ano de 1992. São Miguel Arcanjo, SP.

\begin{tabular}{lcccr}
\hline \hline Mês & \multicolumn{3}{c}{$T\left(\mathcal{O C}^{\circ}\right)$} & $\mathrm{PP}(\mathrm{mm})$ \\
\cline { 2 - 4 } & máxima & mínima & média & \\
\hline jan. & 26,4 & 16,9 & 21,6 & 112,8 \\
fev. & 28,3 & 17,9 & 23,1 & 183,2 \\
mar. & 26,3 & 19,1 & 22,7 & 348,9 \\
abr. & 23,5 & 15,9 & 19,7 & 137,4 \\
maio & 21,1 & 14,0 & 17,5 & 92,6 \\
jun. & 22,3 & 13,8 & 18,0 & 12,5 \\
jul. & 18,8 & 10,0 & 14,4 & 77,0 \\
ago. & 17,8 & 10,2 & 14,5 & 39,0 \\
set. & 18,7 & 12,7 & 15,7 & 179,9 \\
out. & 22,6 & 14,6 & 18,6 & 172,2 \\
nov. & 22,9 & 14,6 & 18,7 & 187,8 \\
dez. & 24,9 & 15,5 & 20,2 & 118,3 \\
\hline \hline
\end{tabular}


Tabela 6. Dados de temperatura (T) e precipitação (PP) do ano de 1993. São Miguel Arcanjo, SP.

\begin{tabular}{lcccc}
\hline \hline Mês & \multicolumn{3}{c}{$T\left({ }^{\circ} \mathrm{C}\right)$} & $\mathrm{PP}(\mathrm{mm})$ \\
\cline { 2 - 4 } & máxima & mínima & média & \\
\hline jan. & 27,0 & 18,2 & 22,6 & 273,6 \\
fev. & 23,9 & 17,4 & 20,6 & 310,9 \\
mar. & 25,2 & 17,5 & 21,3 & 133,7 \\
abr. & 23,6 & 16,6 & 20,1 & 63,2 \\
maio & 20,9 & 13.6 & 17,2 & 112,5 \\
jun. & 19,3 & 11,7 & 15.5 & 118,3 \\
jul & 20,8 & 11,7 & 16,2 & 59,1 \\
ago. & 19,1 & 9,9 & 14,5 & 49,7 \\
set. & 18,4 & 11,7 & 15,5 & 249,3 \\
out. & 22,7 & 14,1 & 18,4 & 154,6 \\
nov. & 23,3 & 14,9 & 19,1 & 108,5 \\
dez. & 25,6 & 13,8 & 19,7 & 183,2 \\
\hline \hline
\end{tabular}

